
NATYONAL INSTITUTE OF STANDAFDS \&

TECHNOLOGY

Research information Center

Gaithersburg, MD 20899 


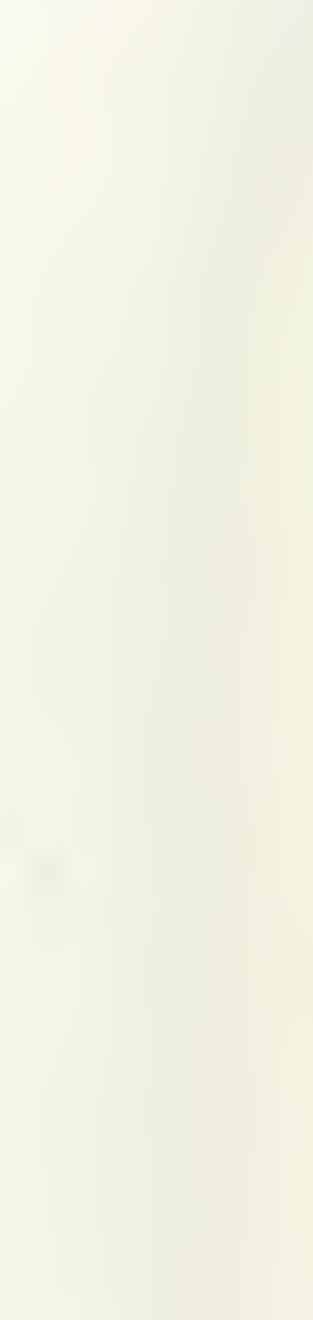




\section{Al1100 990166}

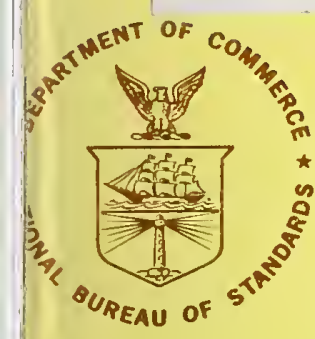

A11100990166

aC100.U558 V158:1977 C.1 NBS-PUB-C 1977
NBS

PUBLICATIONS

\section{NBS MONOGRAPH 158}

\section{U.S. DEPARTMENT OF COMMERCE / National Bureau of Standards}

\section{Corrosion and Protection of Steel Piles in a}

\section{Natural Seawater Environment}

$Q C$
100
1556
$N 0.158$
1977
$C .2$




\section{NATIONAL BUREAU OF STANDARDS}

The National Bureau of Standards ${ }^{1}$ was established by an act of Congress March 3, 1901. The Bureau's overall goal is to strengthen and advance the Nation's science and technology and facilitate their effective application for public benefit. To this end, the Bureau conducts research and provides: (1) a basis for the Nation's physical measurement system, (2) scientific and technological services for industry and government, (3) a technical basis for equity in trade, and (4) technical services to promote public safety. The Bureau consists of the Institute for Basic Standards, the Institute for Materials Research, the Institute for Applied Technology, the Institute for Computer Sciences and Technology, the Office for Information Programs, and the Office of Experimental Technology Incentives Program.

THE INSTITUTE FOR BASIC STANDARDS provides the central basis within the United States of a complete and consistent system of physical measurement; coordinates that system with measurement systems of other nations; and furnishes essential services leading to accurate and uniform physical measurements throughout the Nation's scientific community, industry, and commerce. The Institute consists of the Office of Measurement Services, and the following center and divisions:

Applied Mathematics - Electricity - Mechanics - Heat - Optical Physics - Center for Radiation Research - Laboratory Astrophysics ${ }^{2}-$ Cryogenics $^{2}$ - Electromagnetics ${ }^{2}$ - Time and Frequency ${ }^{2}$.

THE INSTITUTE FOR MATERIALS RESEARCH conducts materials research leading to improved methods of measurement, standards, and data on the properties of well-characterized materials needed by industry, commerce, educational institutions, and Government; provides advisory and research services to other Government agencies; and develops, produces, and distributes standard reference materials. The Institute consists of the Office of Standard Reference Materials, the Office of Air and Water Measurement, and the following divisions:

$$
\text { Analytical Chemistry - Polymers - Metallurgy — Inorganic Materials — Reactor Radiation — Physical Chemistry. }
$$

THE INSTITUTE FOR APPLIED TECHNOLOGY provides technical services developing and promoting the use of available technology; cooperates with public and private organizations in developing technological standards, codes, and test methods; and provides technical advice services, and information to Government agencies and the public. The Institute consists of the following divisions and centers:

Standards Application and Analysis - Electronic Technology - Center for Consumer Product Technology: Product Systems Analysis; Product Engineering — Center for Building Technology: Structures, Materials, and Safety; Building Environment; Technical Evaluation and Application - Center for Fire Research: Fire Science; Fire Safety Engineering.

THE INSTITUTE FOR COMPUTER SCIENCES AND TECHNOLOGY conducts research and provides technical services designed to aid Government agencies in improving cost effectiveness in the conduct of their programs through the selection, acquisition, and effective utilization of automatic data processing equipment; and serves as the principal focus wthin the executive branch for the development of Federal standards for automatic data processing equipment, techniques, and computer languages. The Institute consist of the following divisions:

Computer Services - Systems and Software - Computer Systems Engineering — Information Technology.

THE OFFICE OF EXPERIMENTAL TECHNOLOGY INCENTIVES PROGRAM seeks to affect public policy and process to facilitate technological change in the private sector by examining and experimenting with Government policies and practices in order to identify and remove Government-related barriers and to correct inherent market imperfections that impede the innovation process.

THE OFFICE FOR INFORMATION PROGRAMS promotes optimum dissemination and accessibility of scientific information generated within NBS; promotes the development of the National Standard Reference Data System and a system of information analysis centers dealing with the broader aspects of the National Measurement System; provides appropriate services to ensure that the NBS staff has optimum accessibility to the scientific information of the world. The Office consists of the following organizational units:

Office of Standard Reference Data — Office of Information Activities — Office of Technical Publications - Library — Office of International Standards - Office of International Relations.

\footnotetext{
${ }^{1}$ Headquarters and Laboratories at Gaithersburg, Maryland, unless otherwise noted; mailing address Washington, D.C. 20234.

${ }^{2}$ Located at Boulder, Colorado 80302.
} 


\section{Corrosion and Protection of Steel Piles in a Natural Seawater Environment}

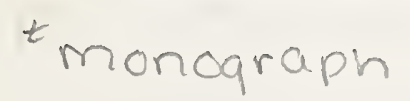

E. Escalante, W.P. Iverson,

W.F. Gerhold, B.T. Sanderson, and R.L. Alumbaugh

Institute for Materials Research

National Bureau of Standards

Washington, D.C. 20234

(Supersedes NBSIR 76-1104)

Sponsored by:

American Iron and Steel Institute

1000 16th Street, N. W.

Washington, D. C. 20036

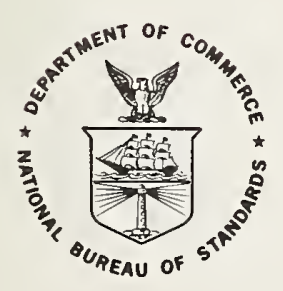

U.S. DEPARTMENT OF COMMERCE, Juanita M. Kreps, Secretary

Dr. Sidney Harman, Under Secretary

Jordan J. Baruch, Assistant Secretary for Science and Technology

U.S NATIONAL BUREAU OF STANDARDS, Ernest Ambler, Acting Director Issued June 1977 


\section{Library of Congress Cataloging in Publication Data}

Main entry under title:

Corrosion and protection of steel piles in a natural seawater environment.

(National Bureau of Standards monograph ; 158)

"Supersedes NBSIR 76-1104."

Includes bibliographical references and index.

Supt. of Docs. no.: C13.44:158

1. Steel piling-Corrosion. 2. Sea-water-Corrosion

I. Escalante, E. II. Series: United States. National Bureau of Standards. Monograph ; 158.

QC100.U556 no. 158 [TA786] 602'.1s [624*.154]

$76-608410$

\section{National Bureau of Standards Monograph 158}

Nat. Bur. Stand. (U.S.), Mongr. 158, 42 pages (June 1977)

CODEN: NBSMA6 


\section{Contents}

1. Introduction $\ldots \ldots \ldots \ldots \ldots \ldots \ldots \ldots \ldots \ldots \ldots \ldots \ldots \ldots \ldots \ldots$

2. Materials and Environment $\ldots \ldots \ldots \ldots \ldots \ldots \ldots \ldots \ldots$

3. Experimental Procedure ...................... 5

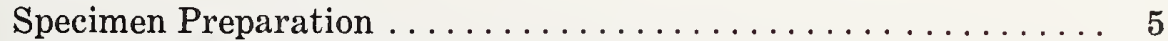

Electrical Measurements ....................... 6

Physical Measurements ..................... 7

4. Results and Discussion $\ldots \ldots \ldots \ldots \ldots \ldots \ldots \ldots \ldots \ldots \ldots$

Bare Piles ............................ 8

Nonmetallic Coatings ...................... 8

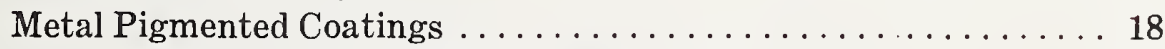

Nonmetallic Coatings on Metal Filled Coatings . . . . . . . . . . 20

Nonmetallic Coating on Metallic Coatings .............. 24

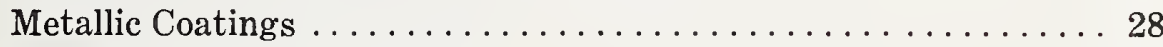

Cathodically Protected Piles . . . . . . . . . . . . . . . 29

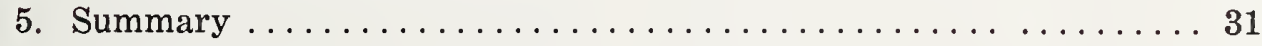

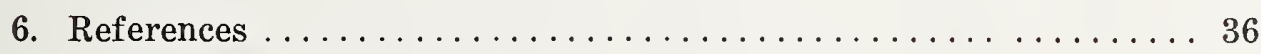

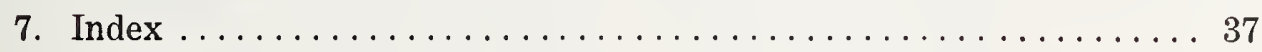





\title{
Corrosion and Protection of Steel Piles in a Natural Seawater Environment
}

\author{
E. Escalante, W. P. Iverson, W. F. Gerhold, B. T. Sanderson,
}

and R. L. Alumbaugh *

\begin{abstract}
This report describes the first eight years of a long term program in which twenty-three coating systems and five cathodic protection systems are evaluated on their ability to protect steel piles in offshore conditions. These systems are made up of nonmetallic coatings, metallic pigmented coatings, nonmetallic coatings on metal filled coatings, nonmetallic coatings on metallic coatings, metallic coatings, and cathodic protection on bare and coated piles.

It includes a description of the annual on site electrochemical coating evaluation and a description of the final physical evaluation made on the piles after removal. The results of these electrochemical and physical evaluations are presented graphically and in tabular form.
\end{abstract}

Key words: Cathodic protection, coating systems; corrosion protection; offshore corrosion; sand erosion; seawater corrosion; splash zone corrosion.

\section{Introduction}

The corrosion of steel piles in seawater is presently being studied by several groups of investigators. Some of these groups have channeled their activities toward laboratory studies $[1,2,3]^{1}$. These studies are of interest in that insight into the corrosion problem can often be obtained by testing under controlled conditions. The very act of controlling conditions, however, can bias the data in subtle and undesirable ways. Other groups have used field tests that expose materials to harbor or bay waters $[4,5$, $6,7]$. Under this exposure, the effect of the tide on corrosion can be closely observed. Corrosion studies in hydrospace are also reported in the literature $[8,9]$. Such work involves the corrosion of materials in very deep water, often a mile or more below the surface.

These studies by various groups produce valuable information on the corrosion of materials under different types of exposure. However, very little work has been reported on the corrosion of steel exposed to actual offshore conditions $[10,11,12]$. Such work is of particular interest now because of the increased need for offshore structures. These structures must withstand all conditions of exposure, and in particular the incessant action of the waves found in open water. In addition, as structures

\footnotetext{
* Civil Enginerping Iaboratory, NCHC. Fort Hueneme, (aliforutia.

Figures in brackets indieate the literature references at the end of this paper.
}

are placed closer to the beach, their exposure to surf action increases. Accompanying this surf is a strong current of water returning to the ocean at the mud line. This under current picks up sand and debris which impinges upon any object in its path. This abrasive action exposes materials to their severest test.

This paper describes some results of the first eight years of a fifteen year program in which a variety of coating and cathodic protection systems are evaluated on their ability to protect steel piles in offshore conditions at Dam Neck, Virginia. It includes a description of the methods used in the evaluation and the results found on these systems.

\section{Materials and Environment}

To withstand the vigorous wave action experienced at the offshore test site, $8 \times 8$ in $(0.20 \mathrm{~m} \times 0.20 \mathrm{~m})$ mild steel H-piles (ASTM A36) weighing $48 \mathrm{lb}$ per $\mathrm{ft}(71 \mathrm{~kg} / \mathrm{m})$ were chosen for exposure. Several 8-in $(0.20 \mathrm{~m})$ diameter pile pipes (ASTM A252) were included to determine the effect of geometry on the deterioration of the coating. Nine mariner steel $8 \times 8$ in $(0.20 \mathrm{~m} \times 0.20 \mathrm{~m})$ H-piles (ASTM A690) were also exposed. All piles were $35 \mathrm{ft}$ long $(10.7 \mathrm{~m})$.

There are twenty-three protective coating systems used on the piles. Two of the twentythree are cathodically protected. In addition, three systems of bare piles are protected with anodes. The systems exposed are listed and described in table 1 . 
Table 1

Description of Steel Pile Systems Exposed to the Atlantic Ocean at Dam Neck, Virginia(a)

\begin{tabular}{|c|c|c|c|c|c|}
\hline $\begin{array}{l}\text { Piling } \\
\text { System } \\
\text { Number }\end{array}$ & Description & $\begin{array}{l}\text { Number } \\
\text { of } \\
\text { Coats }\end{array}$ & $\begin{array}{l}\text { Average } \\
\text { Coating Thickness } \\
\text { on Each Pile } \\
\text { (mils) }\end{array}$ & $\begin{array}{l}\text { Coating Thjckness } \\
\text { Range (b) } \\
\text { Minimum-Maximum } \\
\text { (mils) }\end{array}$ & Remarks \\
\hline 1 & BARE CARBON STEEL & - & - & - & \\
\hline 2 & BARE CARBON STEEL WITH ZINC ANODES & - & - & - & $\begin{array}{l}\text { Protected beneath waterline } \\
\text { with two Zinc anodes (c) }\end{array}$ \\
\hline 3 & $\begin{array}{l}\text { BARE CARBON STEEL WITH ALUMINUM } \\
\text { ANODES }\end{array}$ & - & - & - & $\begin{array}{l}\text { Protected beneath waterljne } \\
\text { with two Aluminum anodes }(c)\end{array}$ \\
\hline 4 & POLYAMIDE CURED COAL. TAR EPOXY & 2 & $\begin{array}{l}A-16 \\
B-16 \\
C-15\end{array}$ & $\begin{array}{l}A=11-20 \\
B=1 D-22 \\
C=10-22\end{array}$ & \\
\hline 5 & POLYAMIDE CURED COAL TAR EPOXY & 2 & $\begin{array}{l}A-20 \\
B-20 \\
C-19\end{array}$ & $\begin{array}{l}A=13-30 \\
B=12-30 \\
C=11-27\end{array}$ & $\begin{array}{l}\text { Protected beneath waterline } \\
\text { with two Zinc anodes (c) }\end{array}$ \\
\hline 6 & POLYAMINE CURED COAL TAR EPOXY & 2 & $\begin{array}{l}A-15 \\
B-15 \\
C-13\end{array}$ & $\begin{array}{l}A=12-2 D \\
8=1 D-28 \\
C=7-20\end{array}$ & \\
\hline 7 & $\begin{array}{l}\text { POLYAMIDE CURED COAL TAR EPOXY } \\
\text { Coal Tar Epoxy and Aluminum Oxide }\end{array}$ & $\begin{array}{l}2 \\
1\end{array}$ & $\begin{array}{l}A-15(33)^{(d)} \\
B-23(38) \\
C-21 .(36)\end{array}$ & $\begin{array}{l}A=7-32(20-40)(d) \\
B=17-30(40+) \\
C=16-30(25-40)\end{array}$ & $\begin{array}{l}\text { Third coat and Aluminum } 0 \times i^{\prime} \\
\text { applied between } 16^{\prime} \text { and } 22^{\prime} \\
\text { from bottom of piles only }\end{array}$ \\
\hline 8 & $\begin{array}{l}\text { ALUMINUM PIGMENTED COAL TAR EPOXY } \\
\text { Amine Cured, Red-Lead Pigmented, } \\
\text { Coal Tar Epoxy Primer } \\
\text { Amine Cured Coal Tar Epoxy } \\
\text { Intermediate } \\
\text { Amine Cured, Aluminum Pigmented, } \\
\text { Coal Tar Epoxy Finish }\end{array}$ & $\begin{array}{l}1 \\
1 \\
1\end{array}$ & $\begin{array}{l}A-27 \\
B-25 \\
C-28\end{array}$ & $\begin{array}{l}A=17-35 \\
B=14-40 \\
C=15-4 D\end{array}$ & \\
\hline 9 & $\begin{array}{l}\text { ALUMINUH PIGMENTED COAL TAR EPOXY. } \\
\text { Epoxy Primer } \\
\text { Amine Cured Coal Tar Epoxy } \\
\text { Intermediate } \\
\text { Amine Cured, Aluminum Pigmented, } \\
\text { Coal Tar Epoxy Finish }\end{array}$ & $\begin{array}{l}1 \\
1 \\
1\end{array}$ & $\begin{array}{l}A-19 \\
8-18 \\
C-18\end{array}$ & $\begin{array}{l}A=12-35 \\
B=12-25 \\
C=13-27\end{array}$ & \\
\hline 10 & HOT DIPPËD ZINC (GALVANIZED) & 1 & $\begin{array}{l}A-g \\
B-8 \\
C-8\end{array}$ & $\begin{array}{l}A=5-13 \\
B=5-15 \\
C=5-14\end{array}$ & \\
\hline 11 & HOT DIPPED ZINC (GALVANIZED) & 1 & $\begin{array}{l}A-7 \\
B-9 \\
C-7\end{array}$ & $\begin{array}{l}A=4-12 \\
8=5-15 \\
C=3-18\end{array}$ & $\begin{array}{l}\text { Protected beneath waterline } \\
\text { with two Zinc anodes }(\mathrm{c})\end{array}$ \\
\hline 12 & $\begin{array}{l}\text { POLYVINYLIDENE CHLORIDE } \\
\text { Formula } 113 / 54, \text { Mi1-L- } 18389 \\
\text { (A1ternate Orange and White } \\
\text { Coats) }\end{array}$ & 7 & $\begin{array}{l}A-7 \\
B-5 \\
C-7\end{array}$ & $\begin{array}{l}A=5-13 \\
B=3-12 \\
C=3-11\end{array}$ & \\
\hline
\end{tabular}


Table 1 (Con't)

\begin{tabular}{|c|c|c|c|c|c|}
\hline $\begin{array}{l}\text { Piling } \\
\text { System } \\
\text { Number }\end{array}$ & Description & $\begin{array}{l}\text { Number } \\
\text { of } \\
\text { Coats }\end{array}$ & $\begin{array}{c}\text { Average } \\
\text { Coating Thickness } \\
\text { on Each Pile }(b) \\
\text { (mils) }\end{array}$ & $\begin{array}{l}\text { Coating Thjckness } \\
\text { Range }(\mathrm{b}) \\
\text { Minimum-Maximum } \\
(\text { mils) }\end{array}$ & Remarks \\
\hline 15 & $\begin{array}{l}\text { COATED FLAMESPRAYED ZINC } \\
\text { Flamesprayed Zinc Wire } \\
\text { Polyvinylidene Chloride, } \\
\text { Formula } 113 / 54, \text { Mil-L- } 18389 \\
\text { (Alternate Orange and White } \\
\text { Coats) }\end{array}$ & $\begin{array}{l}1 \\
7\end{array}$ & $\begin{array}{l}A-12 \\
B-12 \\
C-13\end{array}$ & $\begin{array}{l}A=7-20 \\
B=5-18 \\
C=9-25\end{array}$ & \\
\hline 17 & $\begin{array}{l}\text { PHENOLIC MASTIC } \\
\text { Amine Cured, Red Lead Pigmented, } \\
\text { Phenolic Mastic Primer (with } \\
\text { Mica Filler) } \\
\text { Amine Cured Phenolic Mastic } \\
\text { Finish }\end{array}$ & $\begin{array}{l}1 \\
1\end{array}$ & $\begin{array}{l}\text { A-13 } \\
\text { B-18 } \\
\text { C-14 }\end{array}$ & $\begin{array}{l}A=6-22 \\
B=10-25 \\
C=7-28\end{array}$ & \\
\hline 18 & $\begin{array}{l}\text { COATED ZINC RICH EPOXY } \\
\text { Zinc Rich Epoxy Primer } \\
\text { Polyamide Cured } \\
\text { Coal Tar Epoxy Finish }\end{array}$ & $\begin{array}{l}1 \\
2\end{array}$ & $\begin{array}{l}A-19 \\
B-21 \\
C-22\end{array}$ & $\begin{array}{l}A=10-35 \\
B=13-30 \\
C=15-40\end{array}$ & \\
\hline 21 & $\begin{array}{l}\text { COATED ZINC INORGANIC SILICATE } \\
\text { Zinc Inorganic Silicate Primer } \\
\text { (Self Cured) } \\
\text { Amine Cured Coal Tar Epoxy } \\
\text { Finish }\end{array}$ & $\begin{array}{l}1 \\
1\end{array}$ & $\begin{array}{l}\mathrm{A}-21 \\
\mathrm{~B}-22 \\
\mathrm{C}-19\end{array}$ & $\begin{array}{l}A=10-40 \\
B=11-40 \\
C=14-28\end{array}$ & \\
\hline
\end{tabular}


Table $1\left(\right.$ Con't $\left.^{\prime}\right)$

\begin{tabular}{|c|c|c|c|c|c|}
\hline $\begin{array}{l}\text { Piling } \\
\text { System } \\
\text { Number }\end{array}$ & Description & $\begin{array}{l}\text { Number } \\
\text { of } \\
\text { Coats }\end{array}$ & $\begin{array}{c}\text { Average } \\
\text { Coating Thickness } \\
\text { on Each Pile (b) } \\
\text { (mils) }\end{array}$ & $\begin{array}{l}\text { Coating Thickness } \\
\text { Range(b) } \\
\text { Minimum-Maximum } \\
\text { (mi]s) }\end{array}$ & Remarks \\
\hline 22 & $\begin{array}{l}\text { COATED ZINC INORGANIC SILICATE } \\
\text { Zinc Inorganic Silicate Primer } \\
\text { (Post Cured) } \\
\text { Strontium-Chromate, Iron-0xide } \\
\text { Vinyl Phenolic Primer } \\
\text { Vinyl Mastic Finish }\end{array}$ & $\begin{array}{l}1 \\
1 \\
1\end{array}$ & $\begin{array}{l}\text { A-10 } \\
B-8 \\
C-13\end{array}$ & $\begin{array}{l}A=7-16 \\
B=4-17 \\
C=7-38\end{array}$ & \\
\hline 23 & BARE MARINER STEEL & - & - & - & Low Alloy Steel H-piles \\
\hline 24 & BARE MARINER STEEL WITH ZINC ANODES & - & - & - & $\begin{array}{l}\text { Protected beneath waterline } \\
\text { with two Zinc anodes }(c)\end{array}$ \\
\hline 25 & POLYAMIDE CURED COAL TAR EPOXY & 2 & $\begin{array}{l}A-17 \\
B-16 \\
C-17\end{array}$ & $\begin{array}{l}A=6-40 \\
B=8-28 \\
C=10-30\end{array}$ & Low Alloy Steel H-piles \\
\hline 26 & BARE CARBON STEEL & - & - & - & Carbon Steel Pipe Piles \\
\hline 27 & POLYAMIDE CURED COAL TAR EPOXY & 2 & $\begin{array}{l}A-20 \\
B-17 \\
C-24\end{array}$ & $\begin{array}{l}A=15-28 \\
B=15-24 \\
C=17-30\end{array}$ & Carbon Steel Pipe Piles \\
\hline 28 & $\begin{array}{l}\text { POLYAMIDE CURED COAL TAR EPOXY } \\
\text { Coal Tar Epoxy and Aluminum } \\
\text { 0xide }\end{array}$ & 2 & $\begin{array}{l}A-21(40+)^{(d)} \\
B-21(32) \\
C-16(40+)\end{array}$ & $\begin{array}{l}A=13-30(40)^{(d)} \\
B=12-30(30-40) \\
C=16(40+)\end{array}$ & $\begin{array}{l}\text { Carbon Steel Pipe Piles } \\
\text { Third coat and aluminum oxide } \\
\text { applied between } 16^{\prime} \text { and } 22^{\prime} \\
\text { from bottom of piles only }\end{array}$ \\
\hline 29 & FLAKEGLASS FILLED POLYESTER & 1 & $\begin{array}{l}A-32 \\
B-30 \\
C-34\end{array}$ & $\begin{array}{l}A=18-40 \\
B=17-40 \\
C=15-40\end{array}$ & \\
\hline 30 & BARE CARBON STEEL & - & - & - & \\
\hline 31 & BARE CARBON STEEL & - & - & - & \\
\hline
\end{tabular}

(a) All piles were carbon steel "H" piles unless noted otherwise.

(b) Piles in each system were coated as follows:

A-Piles - Completely coated except for six 1" $\times 6^{\prime \prime}$ bare windows located at intervals along the outside face of the ocean flange of piles.

B-Piles - Completely coated.

C-Piles - Top 23 feet completely coated; bottom 12 feet left uncoated.

(c) Anodes on A and C-piles located in water below MLW; Anodes on B-piles located in the sand.

(d) Values in parenthesis indicate total thickness after application of third coat of Coal Tar Epoxy and Aluminum $0 x$ ide between 16 and 22 feet from bottom of piles. 
Figure 1 illustrates the various zones encountered by the pilings. The imbedded zone is the most stable area of exposure since conditions here remain fairly constant with time. It also is generally the least aggressive from the standpoint of corrosion. Immediately above the imbedded zone is the erosion zone which exposes the protective systems to their severest test. Here, the continual motion of the water due to surf and cross currents lifts the particles of sand from the floor which abrade the surface of the pile. The rate of deterioration of a pile in this zone is generally high. The fouling zone which includes the splash area develops a profusion of plant and animal life. The most corrosive portion of this zone is the splash area. Above the waterline is the atmospheric zone. Wave action is so variable that this zone is not clearly defined. In fact, in unusually heavy wave action during high tide, the atmospheric zone of the pile may momentarily be under water. The corrosiveness of this zone is high.

Characterization data of the ocean water by the U.S. Coast and Geodetic Survey Station at Virginia Beach, Virginia [13] show a mean salinity of 26.8 parts per thousand and a mean temperature of $57.9{ }^{\circ} \mathrm{F}\left(14.4{ }^{\circ} \mathrm{C}\right)$. The salinity has ranged from 18.2 to 37.5 parts per thousand and the water temperature has varied from $33.8{ }^{\circ} \mathrm{F}\left(1.0^{\circ} \mathrm{C}\right)$ to $82.4{ }^{\circ} \mathrm{F}\left(28^{\circ} \mathrm{C}\right)$ over a seven year period.

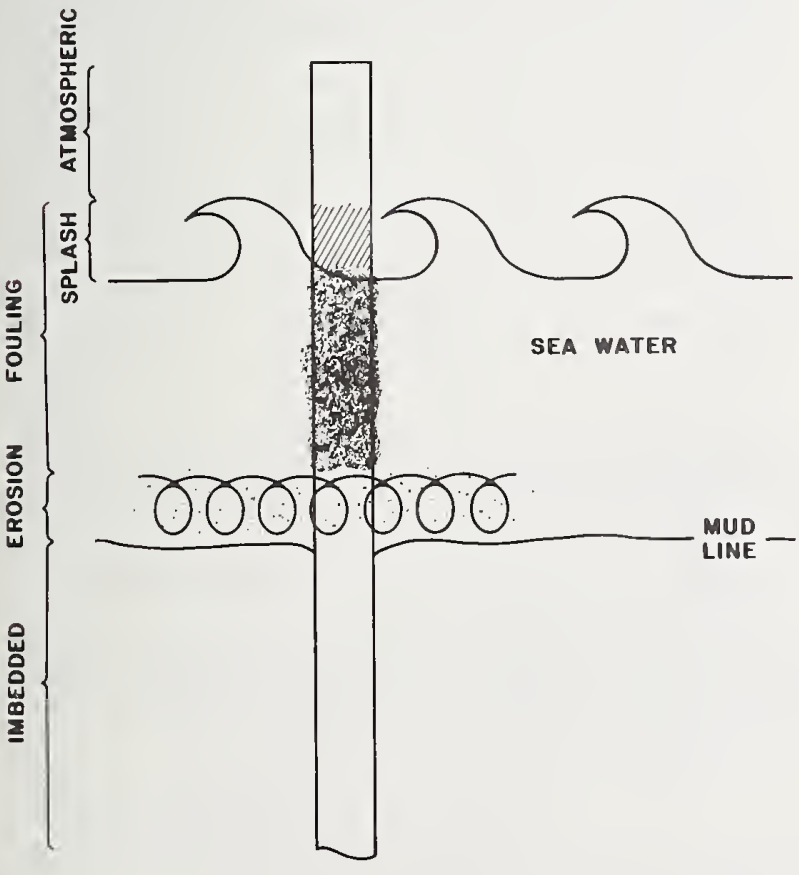

FIGI 13: 1
Borings made ncar the low water line fronting the site indicate that the bottom material consists primarily of fine sand: A thin strata of blue-grey clay and silt, less than $3 \mathrm{ft}$ thick $(0.9 \mathrm{~m})$, exists near the surface. The median diameter of sand particles on the bottom as sampled in 1967 was $0.15 \mathrm{~mm}$ (0.006 in). This small particle size sand is easily carried into suspension by the motion of the water. The amount of suspended material in the immediate vicinity of a pile is even higher due to the increased water velocity resulting from eddy currents the pile generates. In addition to this local sand action, winter storms, hurricanes, and long summer-swells tend to move large volumes of sand causing the bottom elevation to change. Thus, the sand line and the erosion zone changed with time in a nonregular way as illustrated in figure 2.

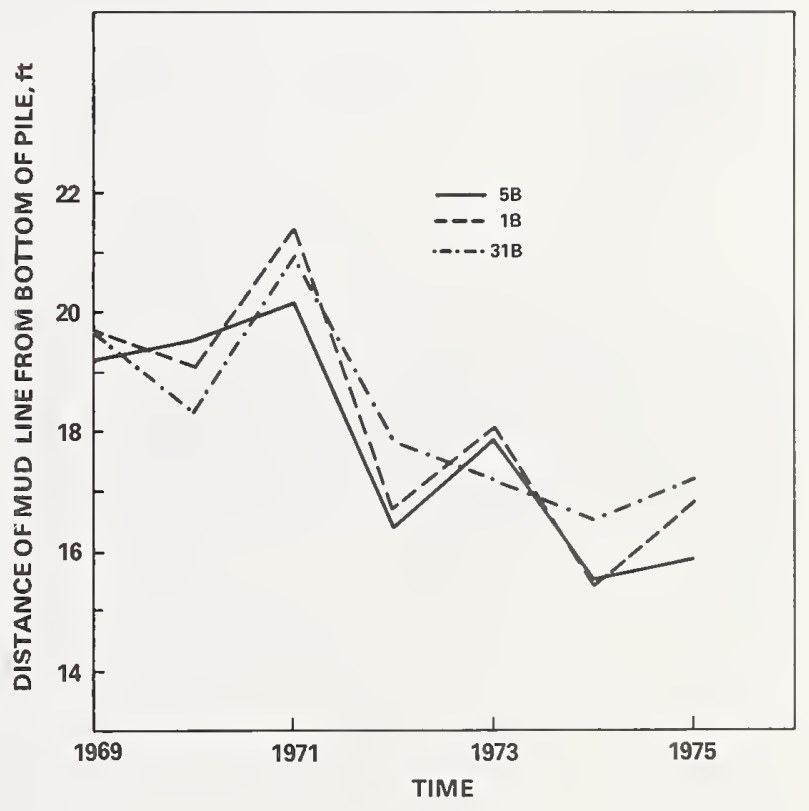

Figure: 2

\section{Experimental Procedure}

Specimen Preparation-A set of three pile specimens, labeled $A, B$, and $C$, was prepared for each system. The A-piles are completely coated except for six windows located along the length of the pile as illustrated in figure 3 . A window is a small area $1 \times 6$ in $(2.5 \mathrm{~cm}$ by 15 $\mathrm{cm})$ which is free of any coating material. Its purpose is to allow evaluation of the undercutting resistance of the protective coating. The B-piles are completely coated. The bottom $12 \mathrm{ft}$ 


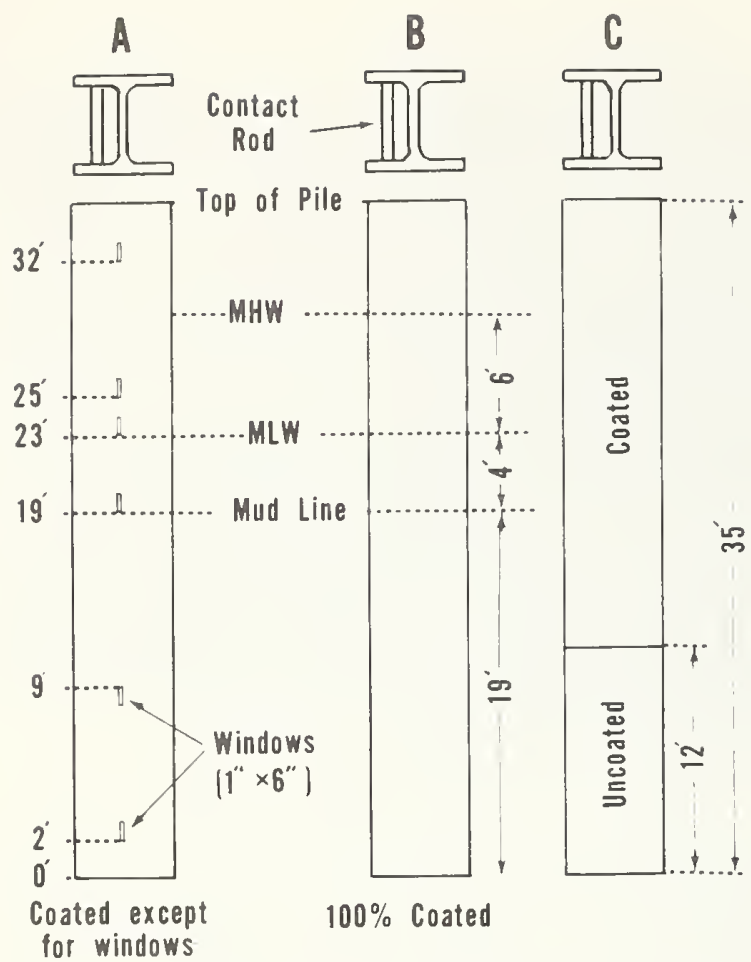

Figrthe 3. Preparation of coated piling specimens.

$(3.6 \mathrm{~m})$ of the C-piles are uncoated. All coatings were applied in accordance to manufacturer's specifications which included sandblasting to a near white finish prior to coating application. Two Type 316 stainless steel bars were welded between the flanges of each of the $\mathrm{H}$ piles. They are located in such a way that one is approximately $2 \mathrm{ft}(0.6 \mathrm{~m})$ above mean high water and the other $2 \mathrm{ft}(0.6 \mathrm{~m})$ below mean high water. Stainless steel bars were buttwelded to the surface of the pipe piles. These bars are contact points used during electrochemical measurements. The pipe piles had a cone-shaped tip welded to the bottom end to facilitate installation. Each of the fifteen cathodically protected piles has two anodes located either in the water or below the mud line.

At the test site, the piles are positioned in three rows as indicated in figure 4 . The distance from shore to the piles is approximately 100 yards $(90 \mathrm{~m})$. In June of 1967 the piles were water-jetted into position with $19 \mathrm{ft}$ (5.7 $\mathrm{m})$ buried in the sand-to ensure adequate stability. Jetting reduces the likelihood of mechanical damage since the pile settles into position from its own weight and the turbulent action of the sand caused by the water jet on the bottom end of the pile. Once in place the jetting pipe is withdrawn.

Electrical Measurements-The steel piles are inspected annually by electrochemical and visual methods. The on-site electrochemical evaluation of the coatings on the piles, is limited to that portion of the pile below the waterline. Above the waterline, coating evaluation is in the form of visual inspection and photography. This annual data is then correlated with the information obtained on the evaluation after the piles are removed from the site. The after removal data is in the form of physical measurements and photographs. Extensive notes are kept on visual observations made during this final inspection.

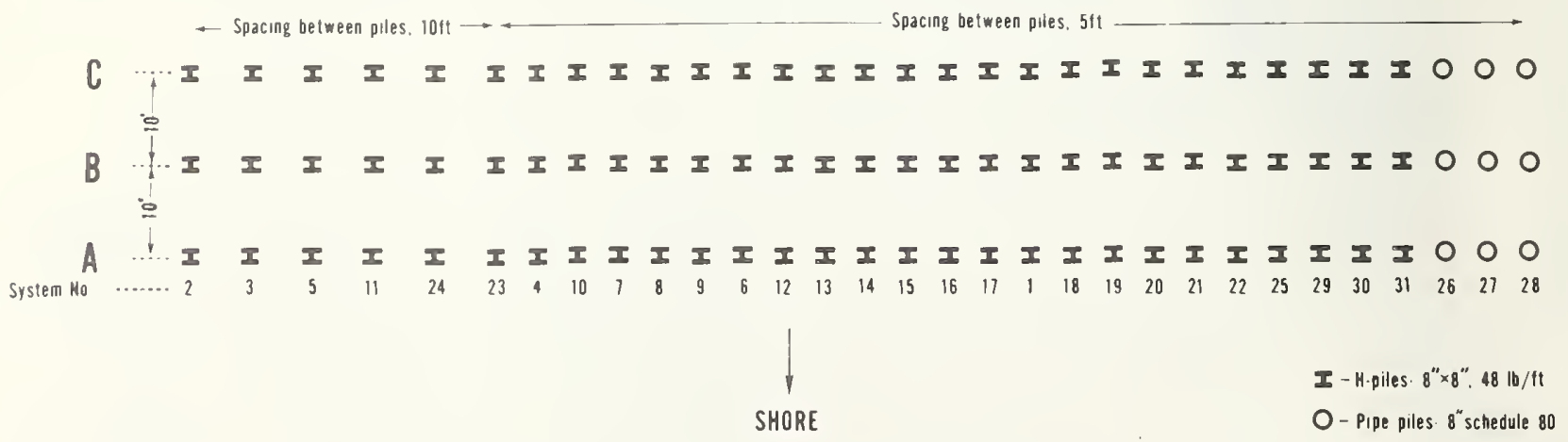

Figure 4. Test pile installation, Dam Neck, Virginia. 
On-site electrical measurements are obtained by having a steel cable suspended above the water between a centrally located pile and a winch on a vehicle parked on the beach. On this cable are hung two insulated 3 conductor electrical cables with vise grips on the ends. Electrical contact is made to the individual piles by clamping a vise grip on the stainless steel bar welded to the piling. The beach ends of the electrical conductor are connected to electronic instrumentation. The strong ocean currents and surf action have made the overwater suspension of the cables necessary.

Two types of electrochemical measurements are made in evaluating the condition of the coatings. The first type, coating index, is primarily a coating resistance measurement for a given change in potential after a five minute period. The potential of the piles with nonmetallic coatings is changed from open-circuit potential (zero applied current) to $-0.850 \mathrm{~V}$ versus $\mathrm{Cu}-\mathrm{CuSO}_{1}$. In the case of metallic coatings a fixed overpotential is applied. For flame sprayed aluminum the overpotential is -0.120 $\mathrm{V}$ and for flame sprayed zinc the overpotential is $-0.150 \mathrm{~V}$. The coating index, $\Delta \mathrm{V}, \Delta \mathrm{I}$, is calculated and compared from year to year giving a measure of the degree of coating deterioration. The coating resistance measurement is also expressed in terms of relative coating effectiveness |12|. This approach compares the coating resistance of each pile to an arbitrary scale which has the bare piles at zero $(0)$ relative coating effectiveness and the best coated pile (7B in 1967) as 100 . The value of relative coating effectiveness between 0 and 100 is based on the relation (not shown) between the corrosion currents and the coating indices for the piles. The second type of measurement is for determining the rate of corrosion of bare piles and piles with metallic coatings. Both the Stern-Geary approach |14| and the polarization break method $|15|$ are used in this case. Since the resistivity of seawater is so low, IR error compensation has been found to be unnecessary.

Potential measurements of the cathodically protected piles were made with a potentiometer using both a $\mathrm{Ag}-\mathrm{AgCl}$ half-cell and a $\mathrm{Cu}-\mathrm{CuSO}$, half-cell. The $\mathrm{Cu}$-CuSO, half-cell was the most convenient to use. It was positioned in the damp sand on the beach and covered to prevent light and heat effects. The $\mathrm{Ag}-\mathrm{AgCl}$ half-cell, submerged in the water, served as a second reference electrode. The protective current on the cathodically protected piles is determined from the cathodic polarization curve [16] as well as the Stern-Geary technique.

The corrosion rate of a pile can be determined by polarization which requires knowledge of the area of the pile. This area is deter- mined by measuring the length of the pile below the waterline at the time polarization measurements are made. Two piles are polarized at a time; one is anodically polarized while the other is cathodically polarized. Electrochemical readings are taken on both piles simultaneously. Power is supplied by a 12 volt storage battery.

Physical Measurements-The first l'emoval for inspection of the piles was made in April 1973, after six years of exposure. Almost one third of the piles were extracted for final inspection. This extraction was done by a 100 ton floating crane that pulled the A-series piles out one at a time. During initial trials an attempt was made at removing two piles at a time, but this was abandoned because of the damage that resulted to the coating and the piles. The piles were then brought to shore for initial cursory inspection and photography. An extensive build-up of vegetable and animal life has developed on the piles. Wide steel spatulas were used to remove this build-up for preliminary inspection. Following this, the piles were shipped to Bethlehem Steel Company where the final intensive inspection took place. Here the coatings on the piles were cleaned and examined for extent of deterioration. The "windows," or intentional interruptions in the coatings described earlier, were examined for development of undercutting (separation of coating from substrate). During this entire process of examination photographs were taken to visually capture the appearance of the coat ings. Upon completion of this process the piles were sandblasted to remove the coatings in preparation for the physical measurements that followed. These measurements, consisting of flange thicknesses, pit depth, and pit densities, were made in the following way. Each pile was marked with chalk at $1 \mathrm{ft}(30 \mathrm{~cm})$ intervals. Using an outside caliper micrometer, flange thickness measurements were made at every foot mark 1 in $(2.5 \mathrm{~cm})$ in from the flange's edge. Finally the deepest pit at every foot of each face (there are eight faces) was found and measured with a micrometer pit depth gauge.

\section{Results and Discussion}

The results will be discussed in seven interrelated parts. First, the corrosion of the bare steel piles will be described. This will be followed by a discussion of the five major coating systems studied (i.e., nonmetallic coatings, metal pigmented coatings, nonmetallic coatings on metal filled coatings, nonmetallic coatings on metallic coatings, and metallic coatings). Finally, the results of the cathodically protected systems will be presented. 
Bare Piles-After six years of exposure to the ocean, the corrosion of the bare piles has been extensive compared to that observed on the protected piles. These control specimens serve as a reference against which all protected piles are compared. Thus, they are important not only in their own right, but as standards of reference. The electrochemical measurements (fig. 5) indicate that their rate of corrosion has been fairly constant with time.

The last measurements of the A-piles were made in 1972 a few months before their removal for visual and physical inspection. Figure 5 shows that the corrosion rate of specimens $1 \mathrm{~A}, 23 \mathrm{~A}$, and $30 \mathrm{~A}$ was virtually identical in the four years the measurements were made. Specimen $23 \mathrm{~A}$ is of special interest because it is a low alloy mariner steel. Their corrosion rate ranges from 1 to 2 mils per year ( 5 to $10 \mathrm{mdd}^{2}$ ) for the entire area of the piles below the waterline. Electrochemical measurements were not made on $26 \mathrm{~A}$ (pipe pile), or $31 \mathrm{~A}$.

The actual observed corrosion as determined from the flange thickness measurements made after cleaning for pile $1 \mathrm{~A}$ is illustrated in figure 6 . The average flange thickness of the pile is plotted for the entire length of the pile. The dashed line indicates the location of the original surface. This thickness measurement reflects the corrosion on both surfaces of the flange. One can see from the diagram that a large part of the corrosion occurs above the high water line. The average corrosion rate in this region is on the order of 8 to 12 mils per year ( 45 to 65 mdd). The region below the high water mark has a relatively low corrosion rate. However, the corrosion damage increases as the erosion zone is approached. The corrosion rate between the high water mark and the mud line ranges from 4 to 8 mils per year ( 20 to $45 \mathrm{mdd}$ ) on the average. Within the erosion zone the observed corrosion is also high. Note that the changing mud line has caused deterioration between 14 and $21 \mathrm{ft}$ ( 4.3 to $6.4 \mathrm{~m}$ ) from the bottom of the pile. This effect will be seen on all piles. In this narrow band the average corrosion rate for pile $1 \mathrm{~A}$ is approximately 9 mils per year (50 mdd).

Specimen $30 \mathrm{~A}$ is practically identical in behavior to $1 \mathrm{~A}$ as illustrated in figure 7 . This figure also displays data on the deepest pits found along the length of the pile. This data indicates that a perforation of the pile developed at about the thirty-two foot level within the six years of exposure. This perforation occurred in the web which is the portion of the pile between the two outer flanges. Pitting

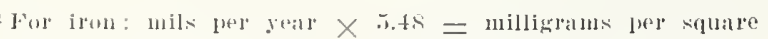
drocintuter lere day" tendency decreases markedly below the mu line.

Figure 8 illustrates the corrosion deterioration observed on Specimen 31A. The bare carbon steel H-pile has developed more metal loss below the mud line than either $1 \mathrm{~A}$ or $30 \mathrm{~A}$, and is of the order of 2 to 3 miles per year (10 to 15 mdd). Its pitting characteristics are very similar to those of $30 \mathrm{~A}$ even to the perforation.

All three of the uncoated carbon steel Hpiles developed at least one perforation through the web in the splash zone. Specimen $23 \mathrm{~A}$, the low alloy steel $\mathrm{H}$-pile, was not removed from the site and, therefore, physical measurements could not be made to verify the electrochemical measurements which indicate that its corrosion rate is essentially identical to that of $1 \mathrm{~A}$ and $30 \mathrm{~A}$ as shown in figure 5 .

The bare pipe pile, $26 \mathrm{~A}$, developed pitting: very similar to that found in the bare $H$-piles with the exception that pitting did not develop below the mud line (fig. 9). Electrochemical measurements were not made on this pile. However, measurements made on $26 \mathrm{~B}$ indicate that the corrosion rate on the bare pipe piles is slightly higher $(25 \%)$ than that of the H-piles. Because of the geometry of the pipe pile, thickness measurements could not be made.

A flange thickness measurement survey of the bare piles revealed that the corrosion at any given depth was not uniform. The greatest corrosion observed was approximately 1 to 2 in $(2.5$ to $5 \mathrm{~cm})$ from the edge of the flange. Since the flange thickness measurements reported here were made in this region of higher than average metal loss, the figures based on these measurements reflect this. Fortunately the survey also revealed that the bias was constant. Thus, all average flange thickness measurements reported for the four bare piles are high by 22 percent \pm 5 percent. The corrosion rates mentioned in the text take this into account.

Nonmetallic Coatings-The nonmetallic coatings will be discussed in two parts. First, the coal tar epoxies will be described, and then similar data on coatings of the same generic type will be presented.

As a group, the coal tar epoxy paints have not performed as well as anticipated in the environment of this program. The electrochemical measurements made on the A-piles in the first five year's are presented in figure 10. In this figure the coating index (electrical coating resistance) versus time is plotted. Thus, as the coating deteriorates more of the metallic substrate is exposed and the overall coating index drops. Similarly the relative coating effectiveness of the system drops. System 6, the poly* amide-cured coal tar epoxy, appears to have deteriorated the most of the coal tar epoxies, but 


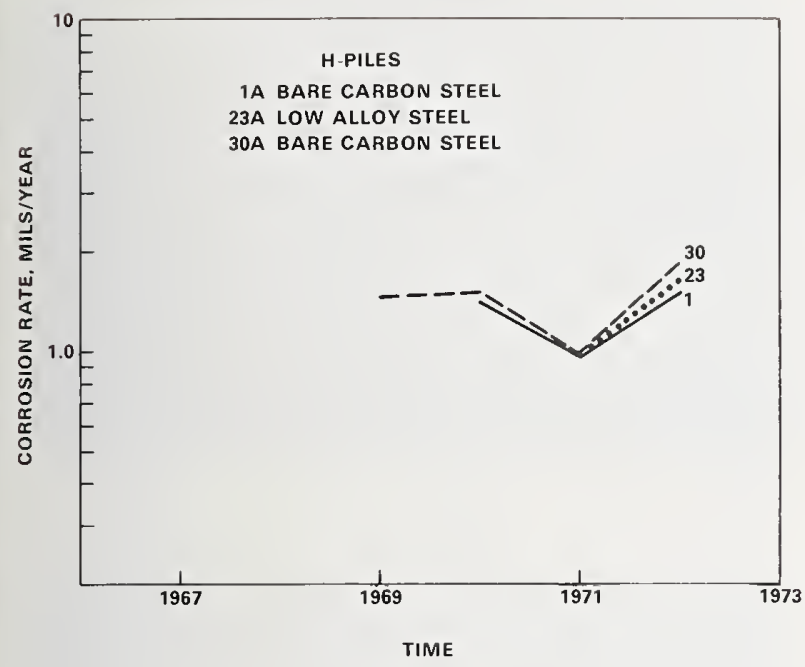

FigLre 5

IA BARE CARBON STEEL

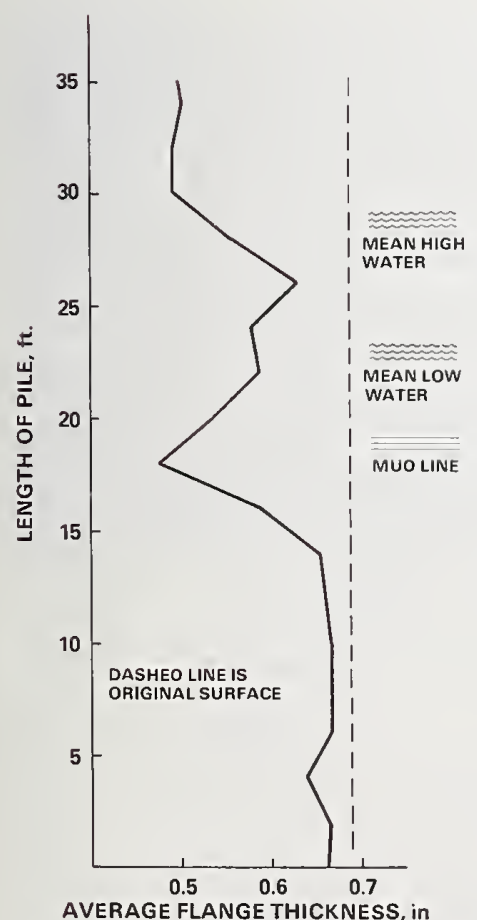

PIT OEPTHS NOT MEASUREO

Figure 6

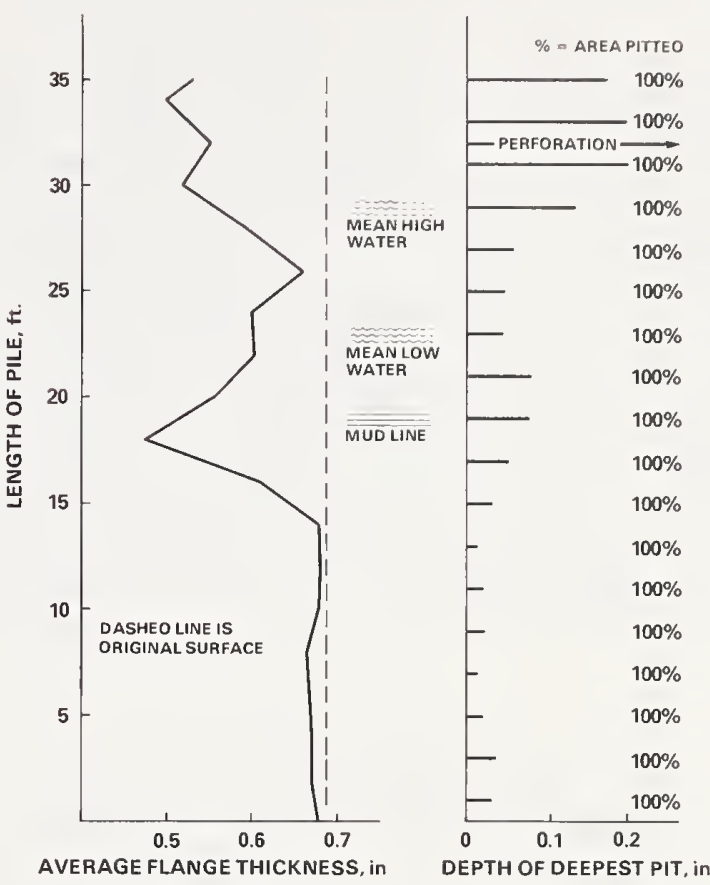

FIGIRE 7

31A BARE CARBON STEEL

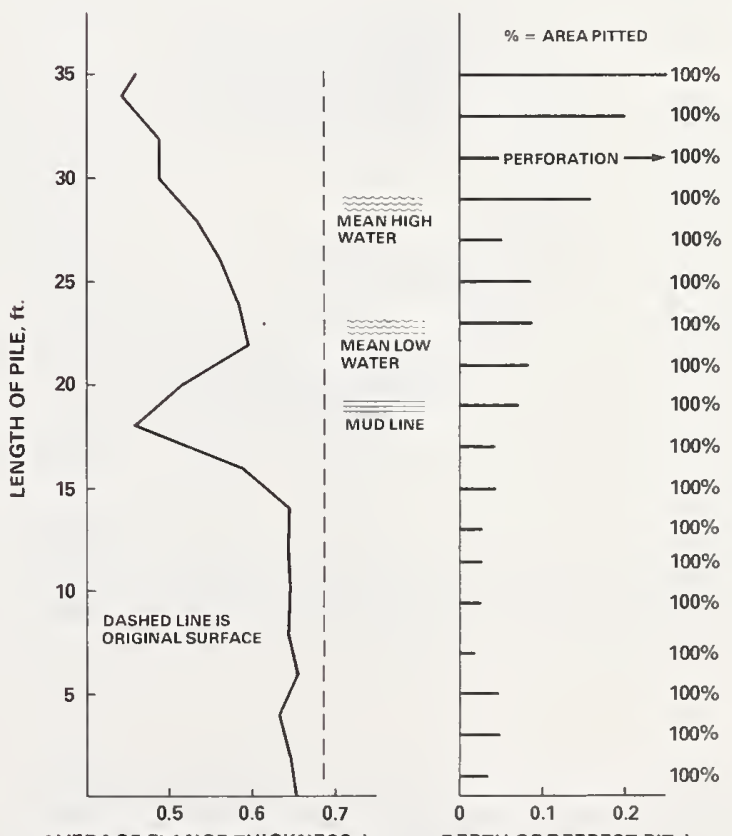

AVERAGE FLANGE THICKNESS, in DEPTH OF DEEPEST PIT, in

Figtre 8 


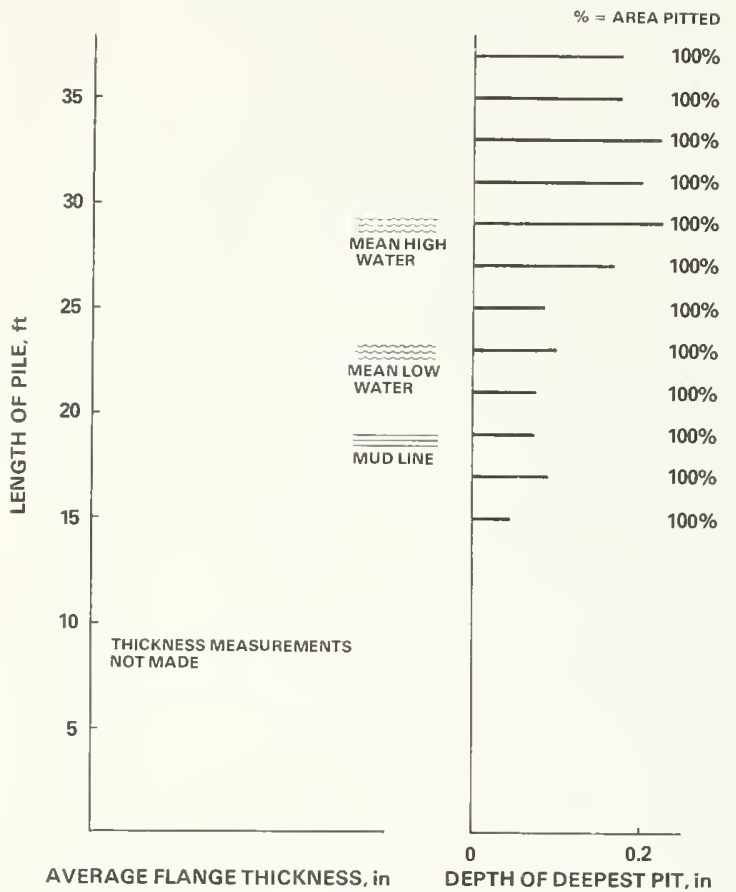

Figure 9

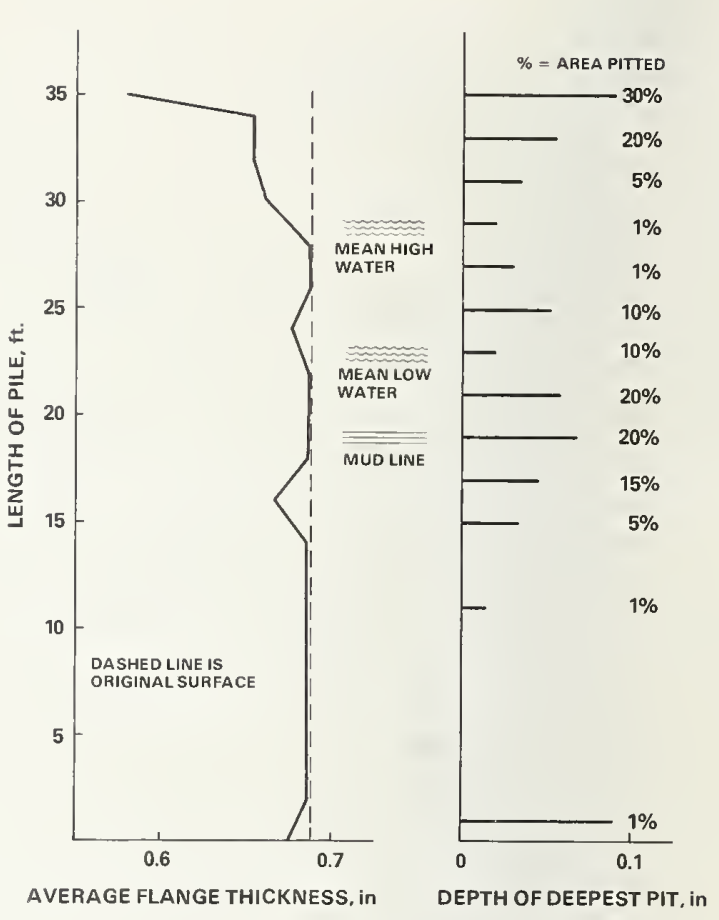

Figure 11

still has a coating effectiveness of 60 after five years of exposure. Figure 11 displays the average flange thickness of pile $6 \mathrm{~A}$ with accompanying pitting. Specimen $6 \mathrm{~A}$ is typical of the coal tar epoxies in that the greatest attack occurred above the high water line. The deepest pit in this region was less than 0.1 in $(0.2 \mathrm{~cm})$. Below the waterline, sand impingment in the erosion zone caused severe damage to the coating. In the atmospheric zone, undercutting of the windows in the coating system is difficult to appraise on this pile because of the extensive general failure of the coating as shown in figure 12 . In the tidal zone, undercutting resistance is much improved, but general attack is still apparent (fig. 13). Below the mud line undercutting of the coating is minor. Mechanical damage to the coating during installation of the pile has caused most of the damage seen in figure 14.

The polyamide cured coal tar epoxy Systems 4,7 , and 25 are somewhat better than $6 \mathrm{~A}$ and have a relative coating effectiveness of 70 in the same period of time as shown in figure 10 . It is of interest to note that System 7, which has the aluminum oxide armor in the erosion zone, initially provided the highest degree of protection to the steel as indicated by the elec- 


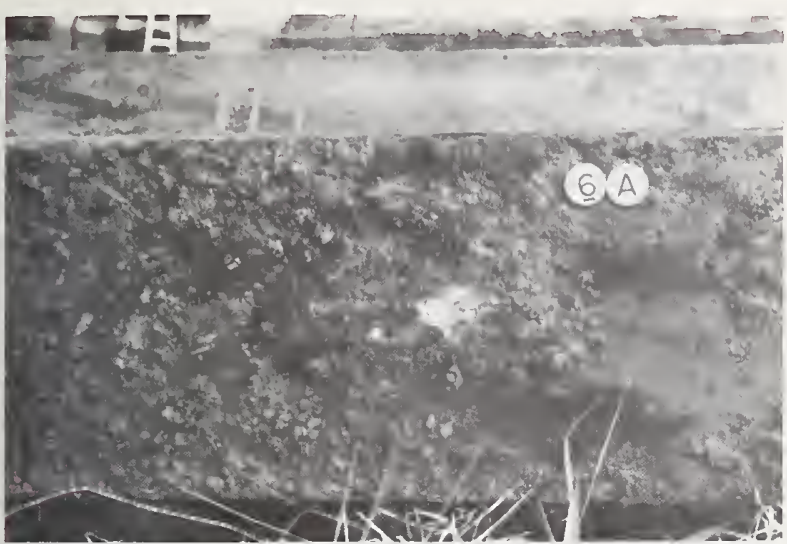

Figure 12

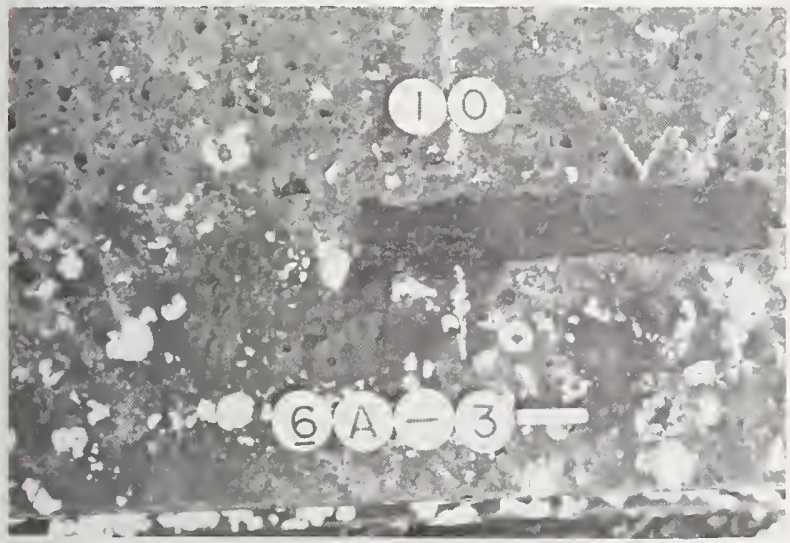

Figure 13

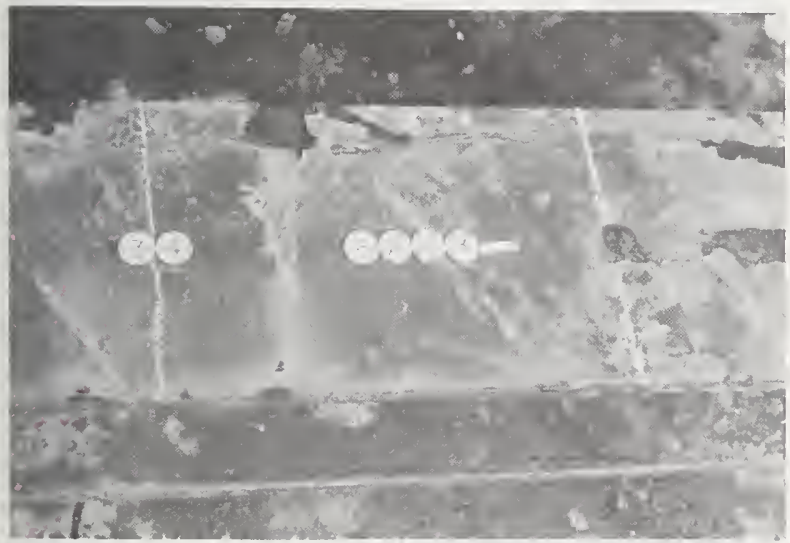

Figure 14

Polvantide cured coal tar epoxy

Poluamine

d trochemical measurements. The physical meas urements of these three piles are illustrated in figures 15, 16, and 17 . The poor resistance of the coal tar epoxy coatings in the atmospheric and splash zones is well indicated in these drawings. Below the waterline, however, they have performed well. Pile 7A shown in figure 16 indicated that the armor coat did reduce the rate of coating deterioration in the erosion zone. Figure 18 is a photograph of the window in the atmospheric zone of pile $7 \mathrm{~A}$. Note the severe undercutting extending half the width of the pile. The window in the tidal zone, that zone between mean high water and mean low water, reveals only a slight amount of undercutting that extends 0.25 in $(0.7 \mathrm{~cm})$ as shown in figure 19. Pitting due to coating failure is evident. Below the mud line undercutting resistance is even better as shown in figure 20 . Generally the coal tar epoxy looks good in this region.

4A COAL TAR EPOXY

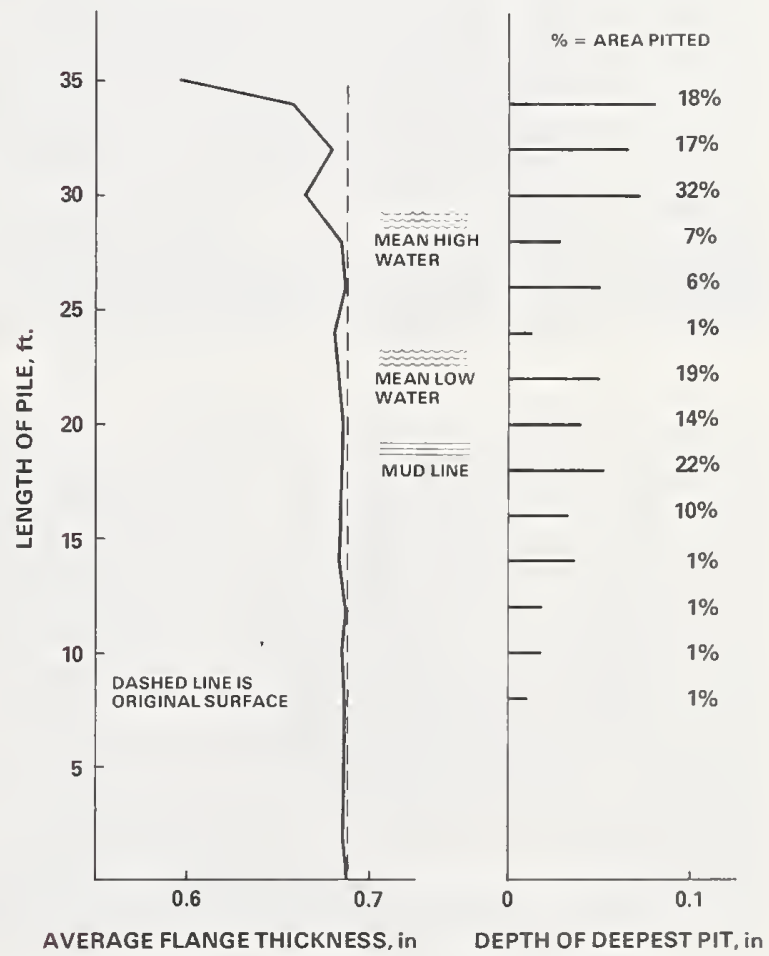

Figure 15

Pile 4A shown in figure 21 lacks the armor protection and has developed greater deterioration of the coating in the erosion zone as compared to pile $7 \mathrm{~A}$. The appearance of the window 
7A COAL TAR EPOXY PLUS ARMOR

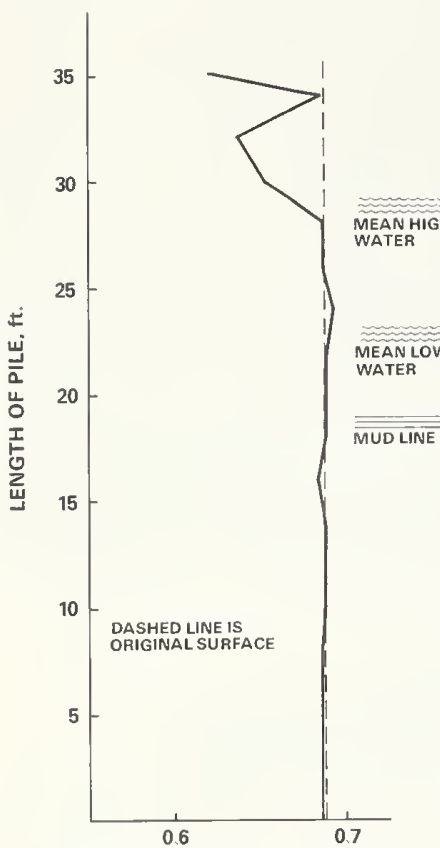

AVERAGE FLANGE THICKNESS, in

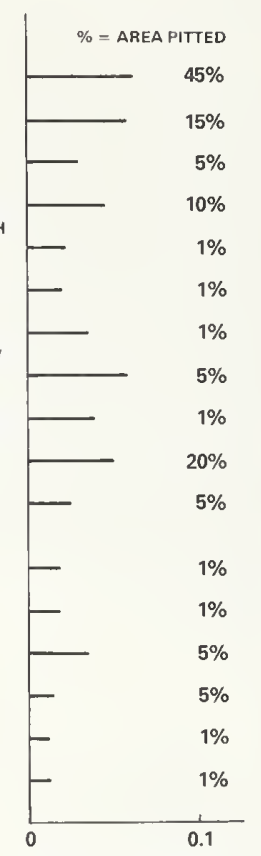

DEPTH OF DEEPEST PIT, in

Figure: 16

25A COAL TAR EPOXY ON MARINER STEEL

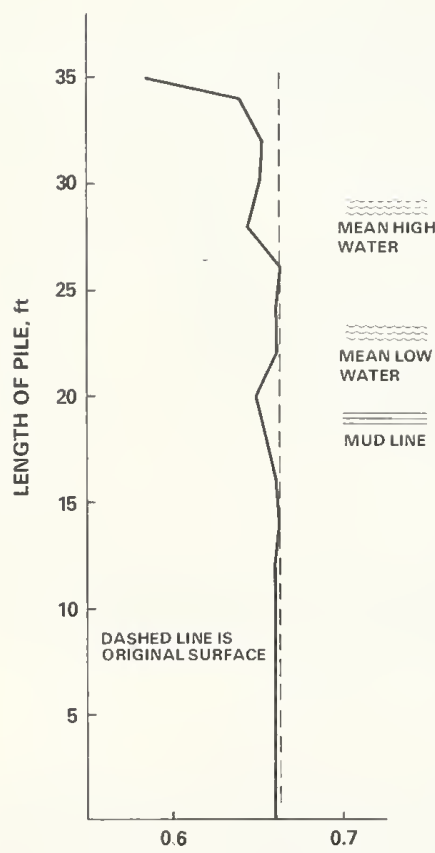

AVERAGE FLANGE THICKNESS, in

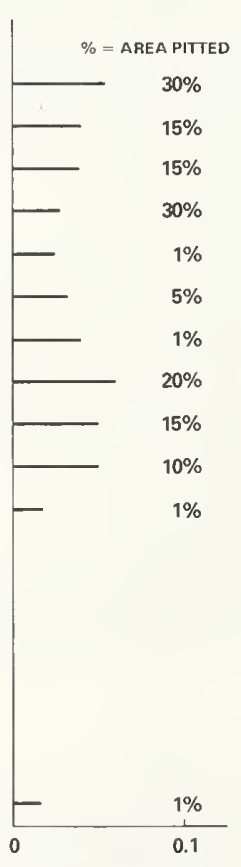

DEPTH OF DEEPEST PIT, in

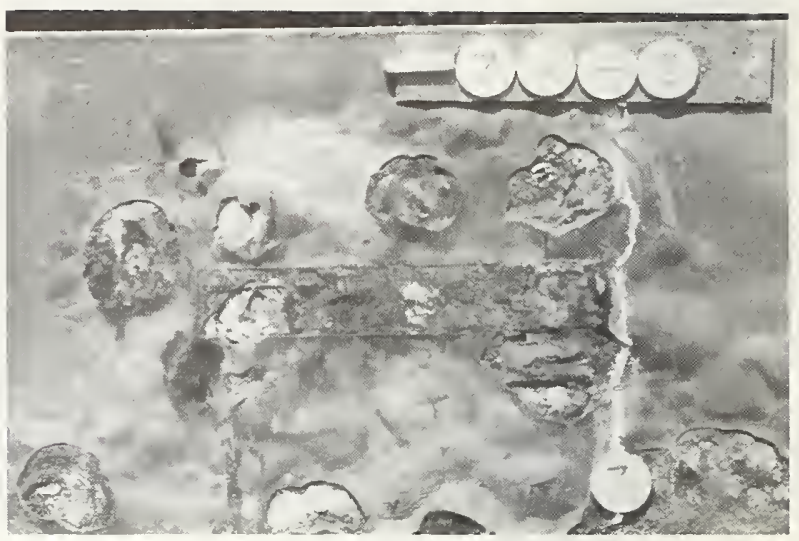

Figure 18

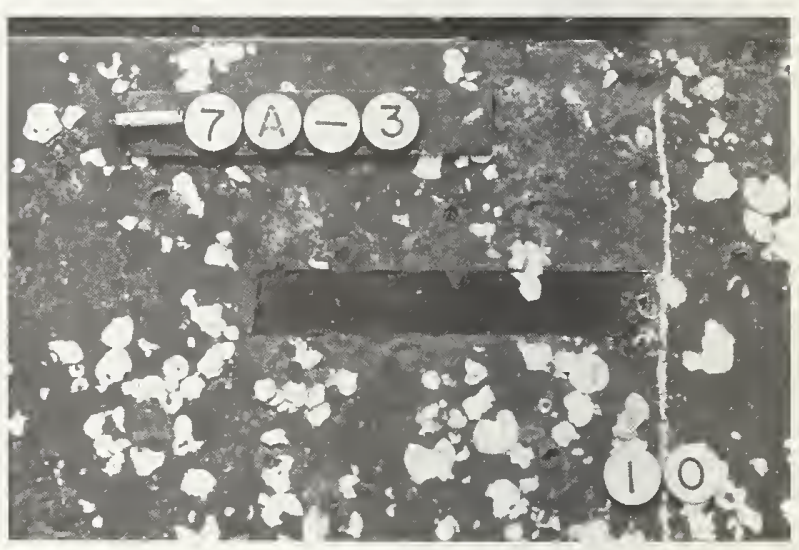

Figuke: 19

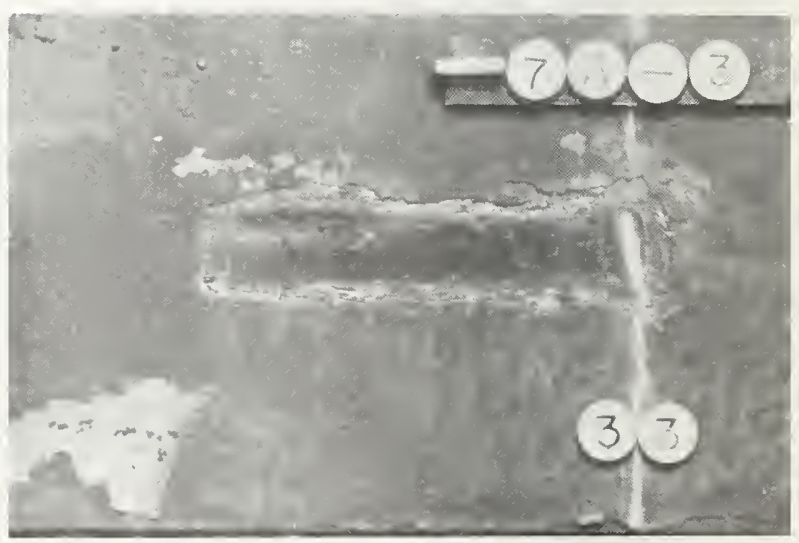

Figure 20

Polyamide cured coal tar epox!

Figt Re 17 


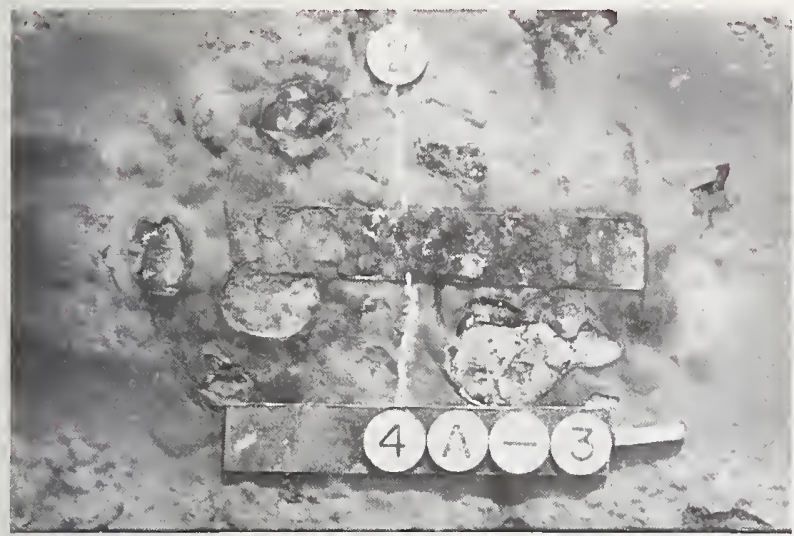

Fignite: 2]

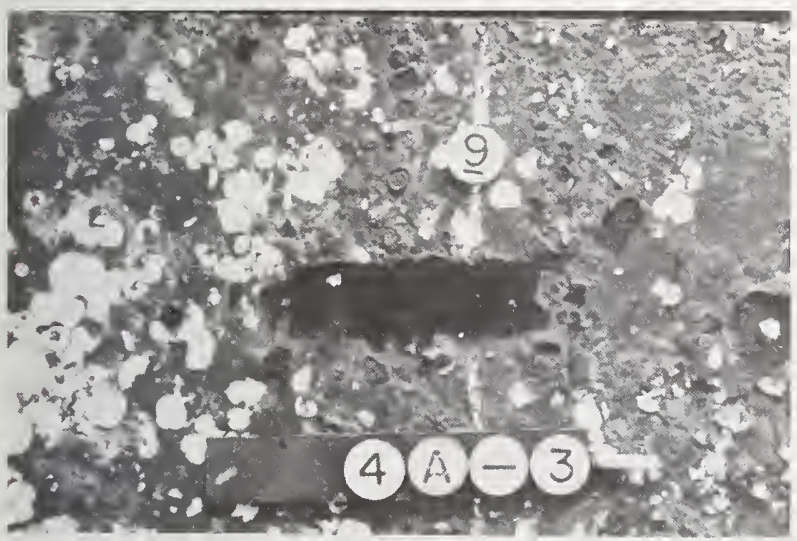

FIGUKE 22

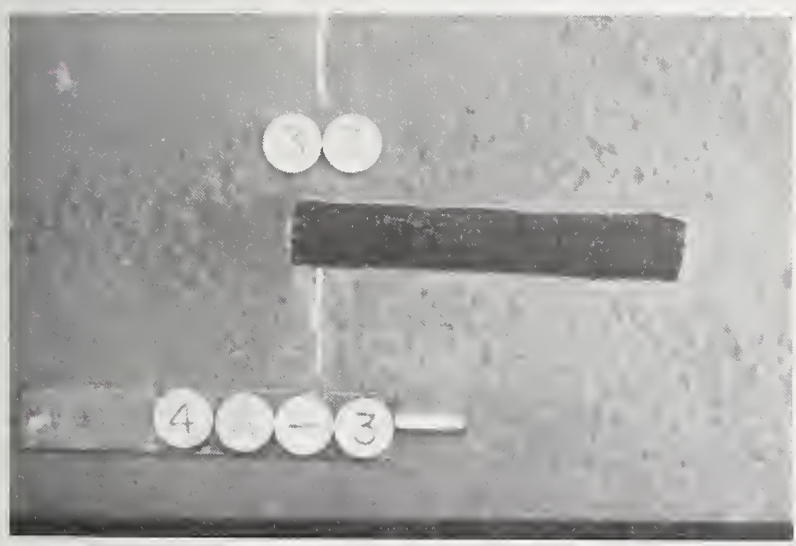

Figtre, 25

Polyamide cured coul tar epoxi

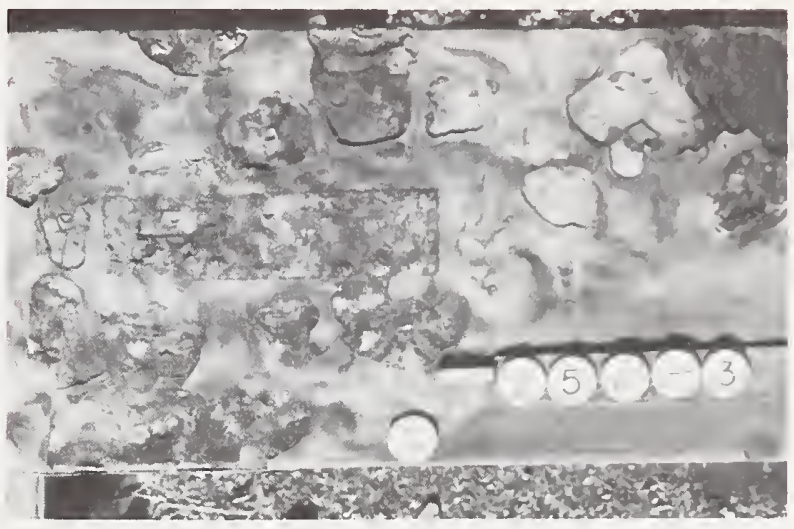

Figuke 24

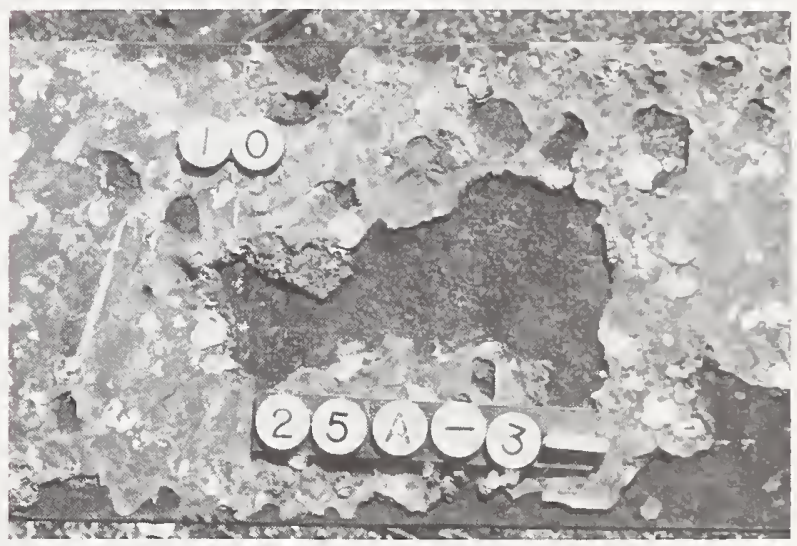

Figure 23

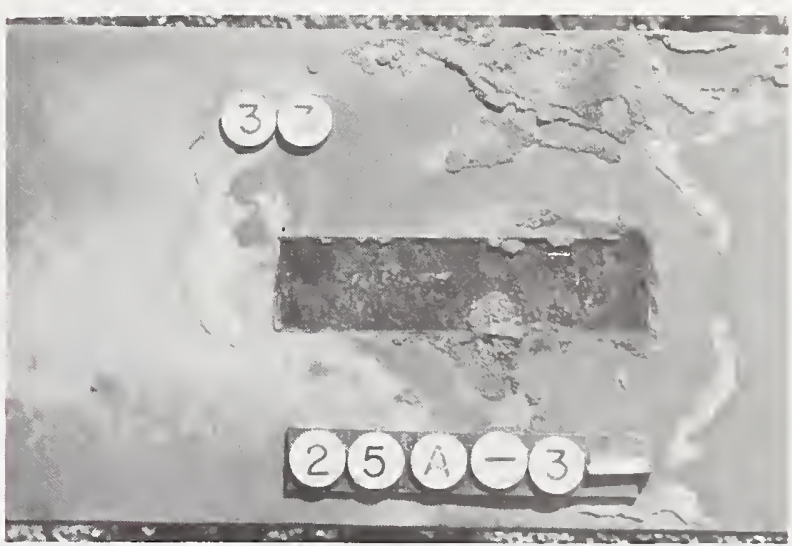

Figute 26

Polvamide cured roal sar epon 


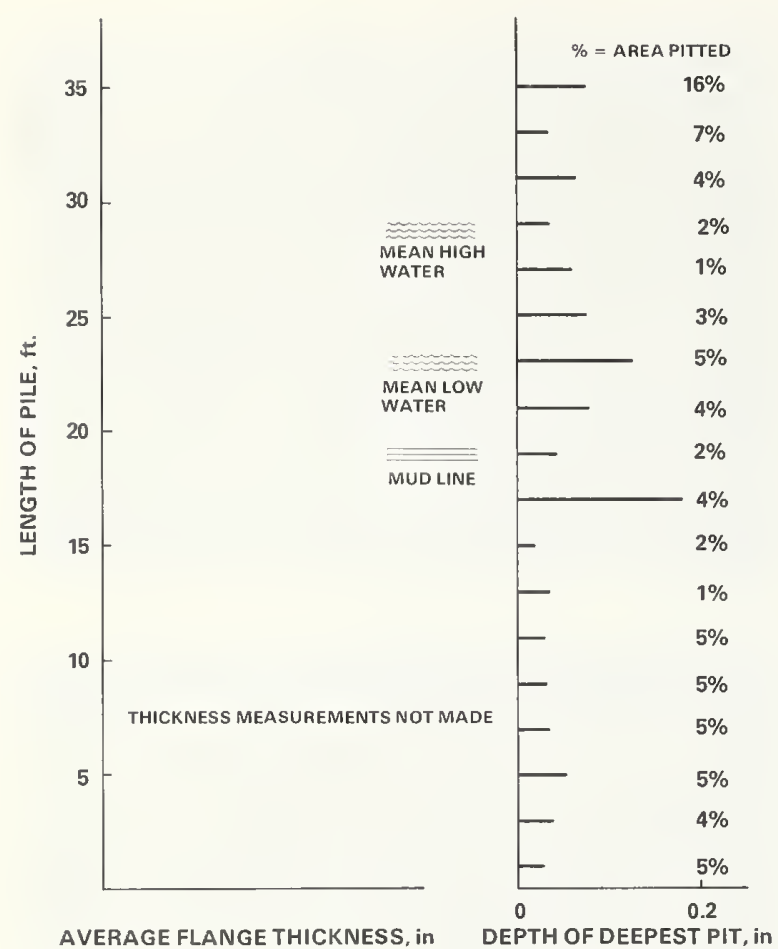

Figure 27

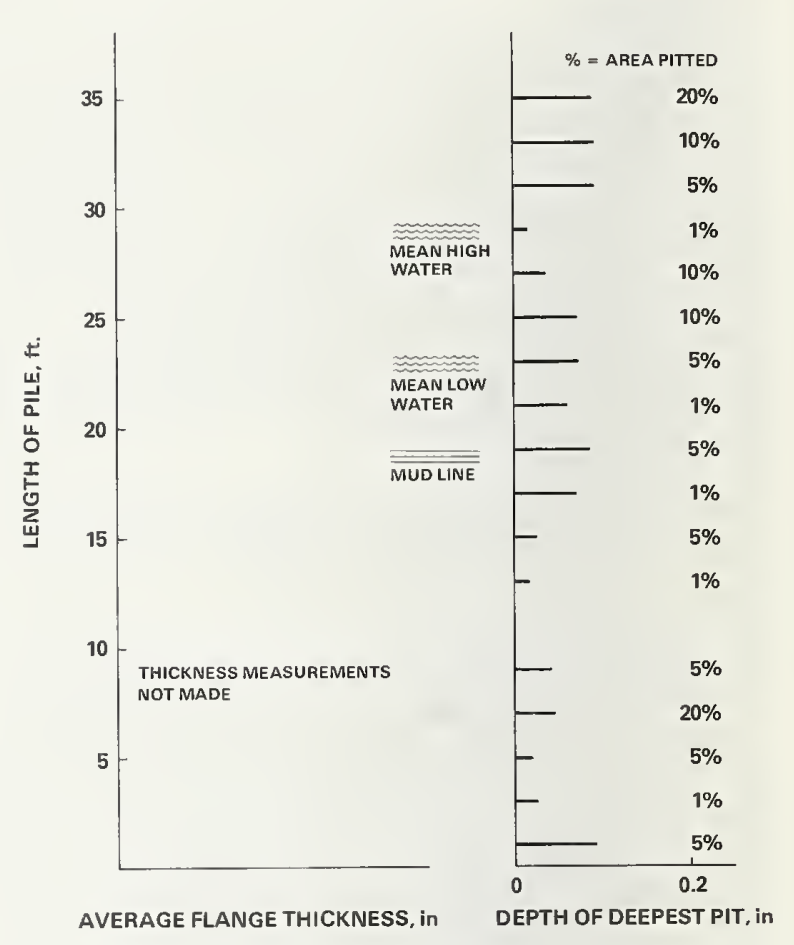

Figure 28 in the atmospheric zone of pile $4 \mathrm{~A}$ is similar to that of $7 \mathrm{~A}$ after six years of exposure as figure 21 shows. In the tidal zone, however, the window on $4 \mathrm{~A}$ has undergone considerable damage not readily seen in figure 22 . Undercutting in this area extends almost 1 in $(2.5 \mathrm{~cm})$ beneath the coating. General damage to the coating in the surrounding area is also apparent. Below the mud line the coating is in excellent condition with practically no undercutting as shown in figure 23.

In the erosion zone, the coal tar epoxy on mariner steel, System 25, has not fared as well as the same coating on carbon steel (System 4A). Figure 17 indicates loss of metal at the flange in this area. Its pitting resistance below the mud line, however, is far better than any of the other similarly coated piles. Undercutting of the coating in the atmospheric zone is severe as illustrated in figure 24. Coating damage in the tidal zone is also very extensive (fig. 25). Below the mud line, however, figure 26 illustrates that the coal tar epoxy on mariner steel has not been undercut.

In general, the coal tar epoxies on the H-piles have deteriorated considerably in the atmospheric zone with resulting metal losses averag- ing 2.3 mils per year ( $13 \mathrm{mdd}$ ). Below the water line metal loss has been minimal and on the order of 0.25 mils per year $(1.4 \mathrm{mdd})$. Undercutting at windows ranged from severe in the atmospheric zone to insignificant below the mudline. From an electromechanical standpoint, the coal tar epoxy coated pipe piles look very good as illustrated in figure 10. Their rate of deterioration has been low, and after five years they have a coating effectiveness above 85 .

The physical measurements on the pipe piles consists only of pit depth measurements (figs. 27 and 28) as meaningful wall thickness measurements were not practical. These observations indicate that though there were fewer coating failures on the pipe piles, (\% area pitted) as compared to the H-piles, the resulting pits were deeper on the pipe piles. The deepest pit in the erosion zone of $27 \mathrm{~A}$ was almost 0.2 in $(0.5 \mathrm{~cm})$ deep. Undercutting of the coating on pile $27 \mathrm{~A}$ extends about 2 in $(5 \mathrm{~cm})$ beyond the edge of the window as shown in figure 29, and is considered severe. In the tidal zone undercutting resistance is improved. Undercutting extends $0.5 \mathrm{in}(1 \mathrm{~cm})$ at the most (fig. 30). Figure 31 illustrates that below the 


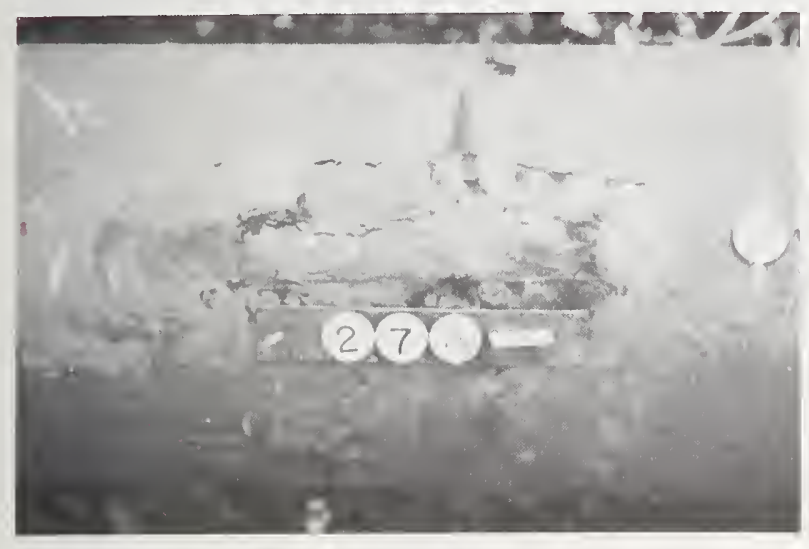

Figule 29

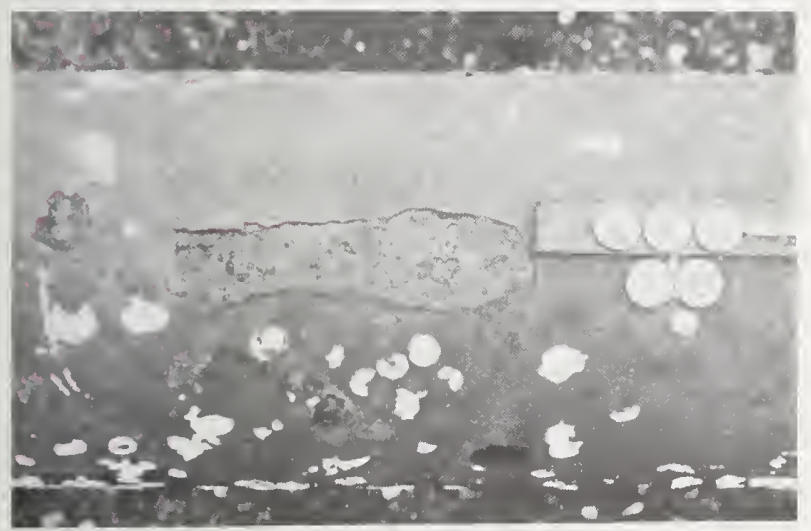

Figtike 30

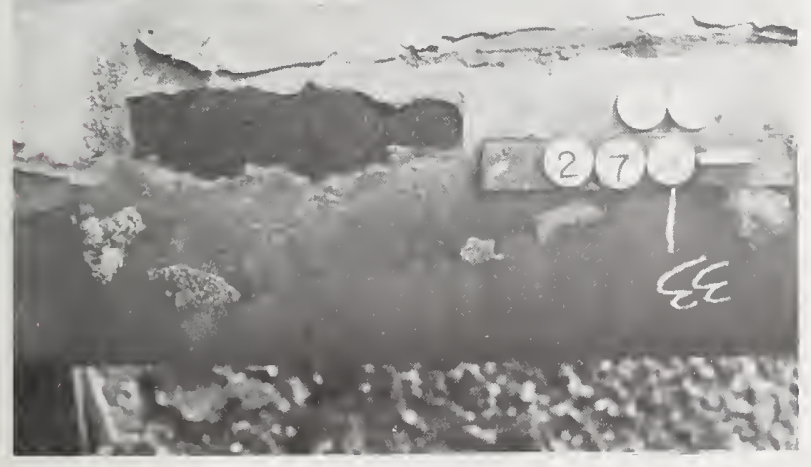

FICURE 31

Polvamine rured coal tar epox.

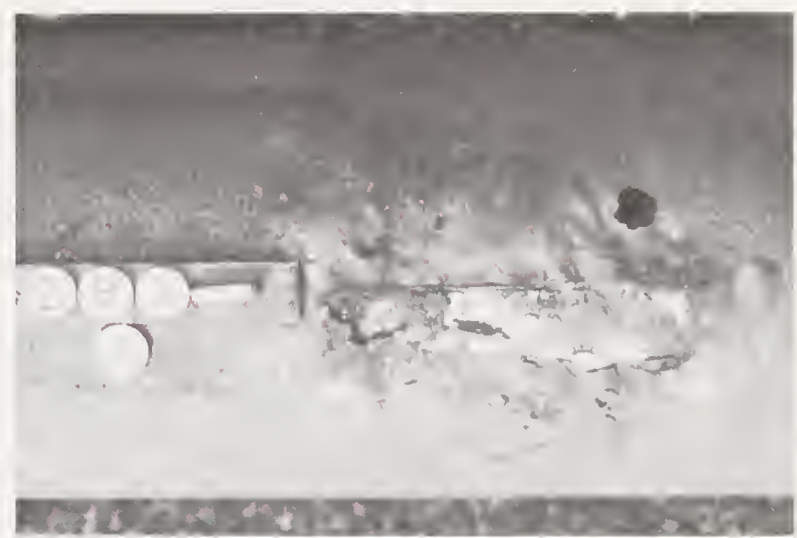

Figurk: 32

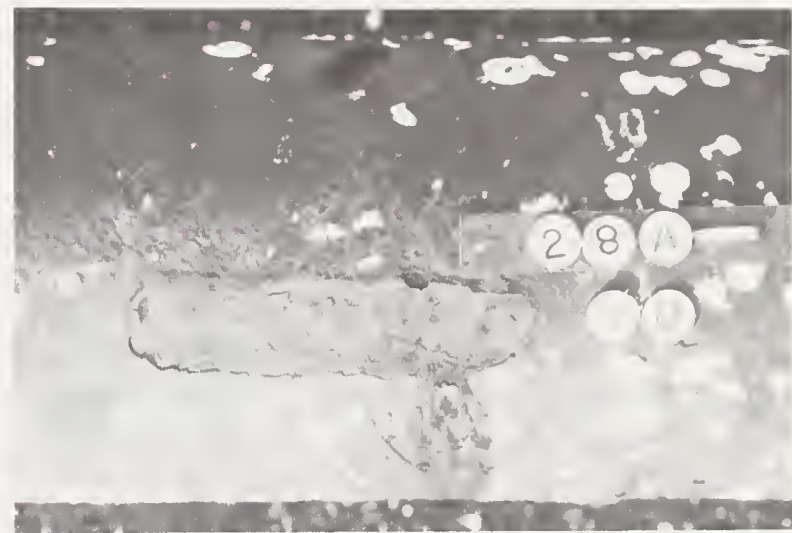

Figure 33

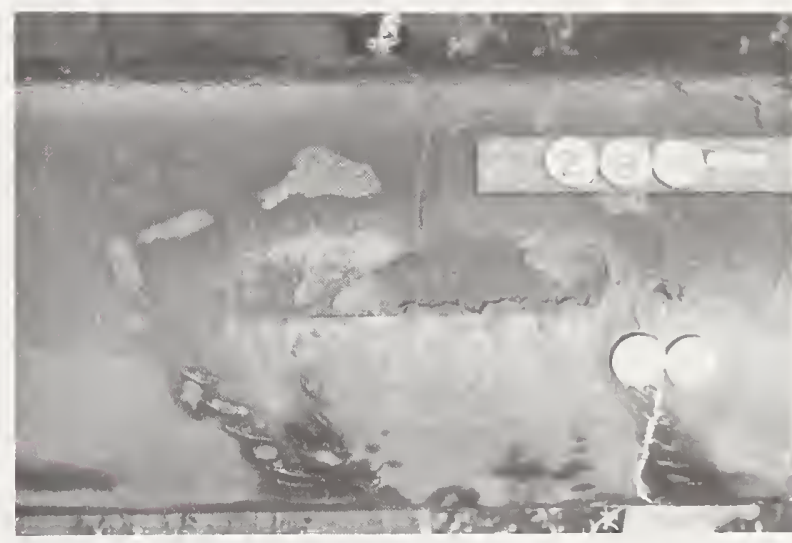

FIGUKE 34

Polyamide enred coal tar epoxy 


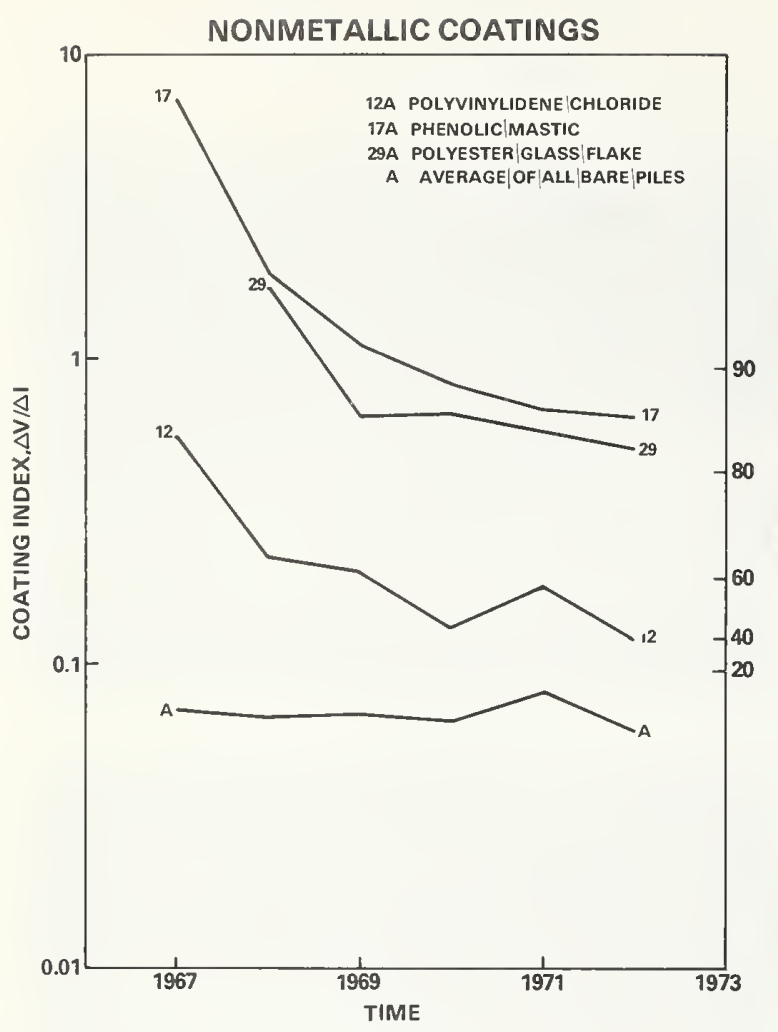

Figne 35

mud line, undercutting of the coating has progressed almost 1 in $(2.5 \mathrm{~cm})$ from the edge of the window. Coating delamination is also visible in this photograph. The windows in the coat ing on pile $28 \mathrm{~A}$ are almost identical in appear ance to those on $27 \mathrm{~A}$. In the atmospheric zone deterioration is extensive (fig. 32). In the tidal zone undercutting of the coating is moderate (fig. 33) with some mechanical damage visible. Below the mud line undercutting has progressed at least 1 in $(2.5 \mathrm{~cm})$ from the edge of the window (fig. 34).

The second group of nonmetallic coatings in the program are Systems 12 (Polyvinylidene Chloride), 17 (Phenolic Mastic), and 29 (Polyester Glass Flake). The electrochemical measurements on these piles are given in figure 35 . This data reveals the good resistance to deterioration of Specimen 17A. Specimen 29A is almost as good, and both have a coating effectiveness above 80 . The physical measurements for pile $17 \mathrm{~A}$ are illustrated in figure 36 . The resistance to deterioration of the phenolic mastic has been very good over the entire surface of the pile in the six years of exposure. Even in the erosion zone the amount of pitting was low with maximum pit depths less than 0.1 in $(0.2 \mathrm{~cm})$. The maximum degree of cor-
17A PHENOLIC MASTIC

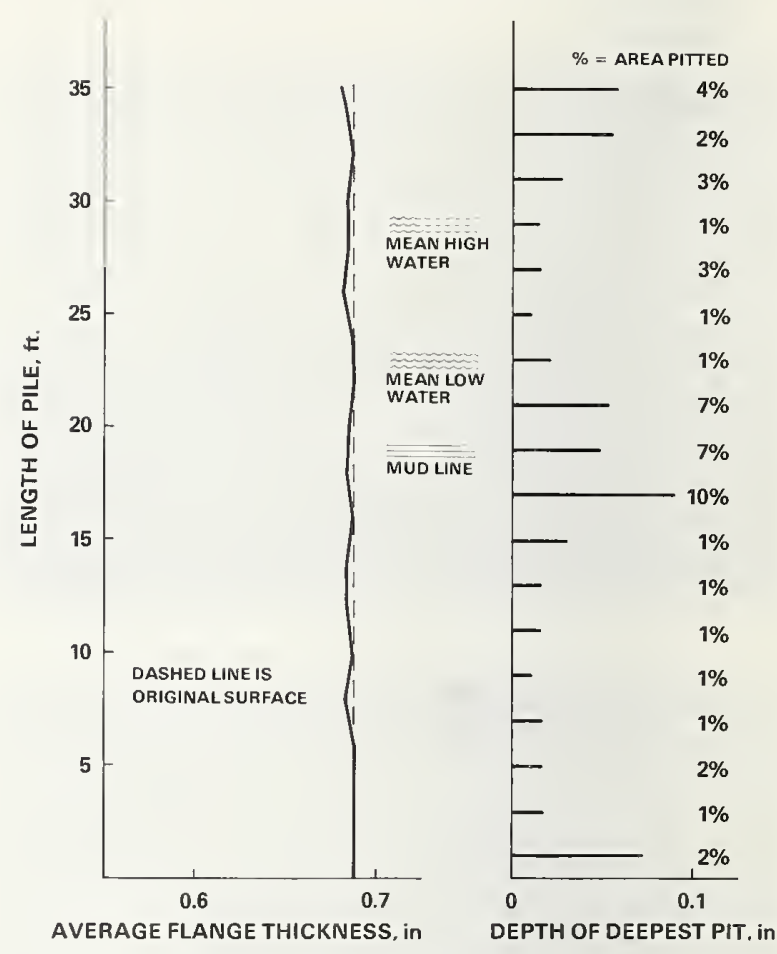

Figure 36

rosion observed on this system was just below the mean high water line with a rate of 0.15 mils per year $(0.8$ mold $)$. In the atmospheric zone, the window in the coating suffered only moderate undercutting as shown in figure 37 with a maximum penetration of 1 in $(2.5 \mathrm{~cm})$ or less. The same figure shows that the coating in the vicinity of the window is still in excellent condition. Most of the rusty color is surface staining of the coating. In the tidal zone (fig. 38) undercutting extends less than 0.25 in $(0.6 \mathrm{~cm})$ beyond the window. Some coating failure at the edge of the flange is visible in this photograph. Below the mud line undercutting was practically nonexistent as shown in figure 39. The dark globular material on the window is an adhering mud and sand mixture that apparently does not affect the phenolic mastic.

The polyester glass flake, System 29, has an average coating thickness of 32 mils $(0.8 \mathrm{~mm})$. This system has displayed very good resistance to deterioration. Figure 40 is a plot of the physical measurements made on this coating. It is apparent from this data that the degree of pitting is minor. Flange thickness measurements were not made for two reasons. First, coating breakdown was so minimal that little 


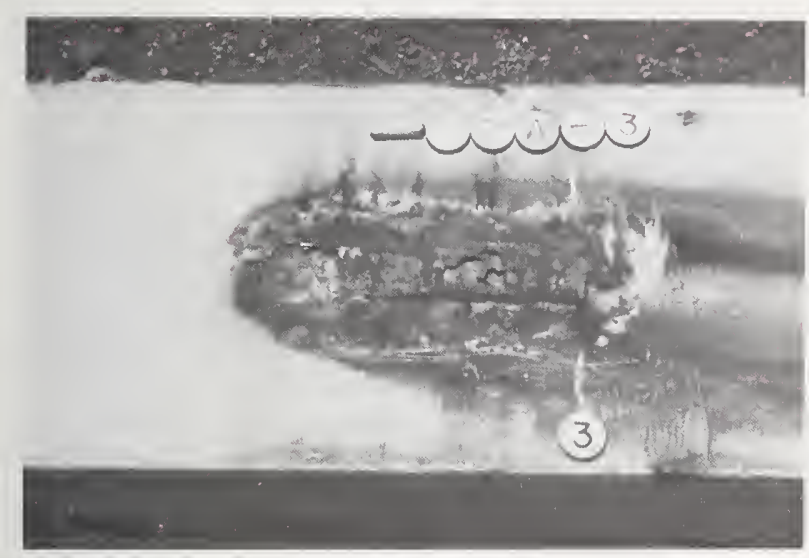

Figure 37

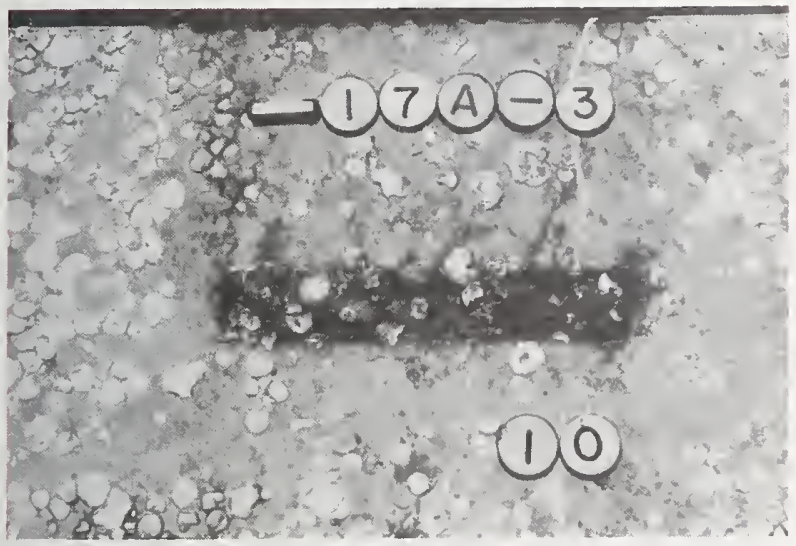

Fuguke 38

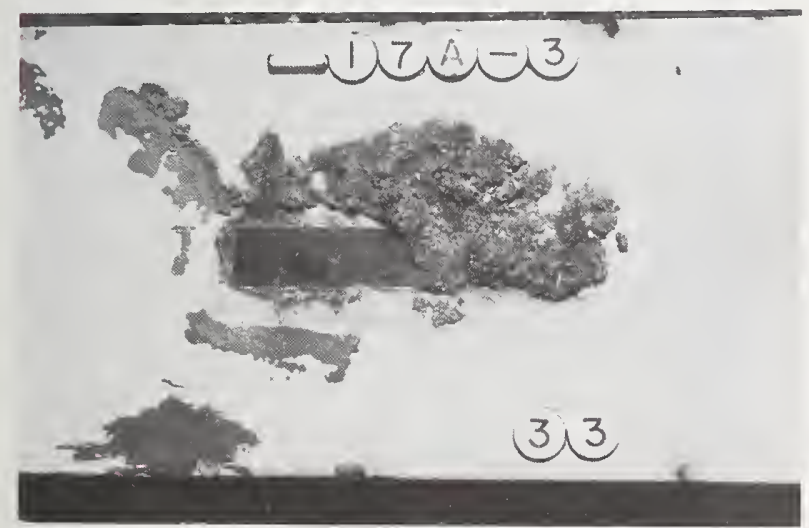

FIGULE 39

Phenolic mastic would be gained by removing the coating for examination. Secondly, and equally important, it was very difficult to remove the polyester glass flake by sandblasting. The severest deterioration of the coating, which was minor, occurred at the edges of the flange in the erosion zone. Beyond that there was little deterioration of the coating. Even in the atmos pheric or the splash zones little damage devel oped. The tendency to undercut as indicated at a window in the atmospheric zone is shown in figure 41. Undercutting extends at most 1 in $(2.5 \mathrm{~cm})$ from the original edge of the window. The coating was chipped away from the edge of the damaged area to reveal the degree of undercutting. In the tidal zone the degree of undercutting was minor as seen in figure 42. Not visible in this photography is damage at the edge of the flange. The coating was also removed from around the window below the mud line. The photograph of this window, figure 43 , indicates that undercutting extends 0.5 in $(1.2 \mathrm{~cm})$ under the coating. In general, the polyester glass flake coating, System 29, performed exceptionally well, developing only a few scattered pits over its surface. Though physical measurements were not complete, from its appearance one can estimate the total corrosion rate to be less than 0.1 mil per year ( $0.5 \mathrm{mdd})$ over the six years of exposure.

Figure 35 illustrates the degree of deterioration of polyvinylidene chloride, System 12, as measured by electrochemical means. Without question, this system has given the least amount of protection to the steel. Initially it had a coating effectiveness of slightly more than 80. After five years the effectiveness of the coating dropped to 40 . Figure 44 illustrates the data taken from the physical measurements. It is apparent from this figure that while the resulting corrosion of the pile is no where near that observed on the bare piles, it is considerably more than that seen on any of the piles protected by other types of nonmetallic coatings. The worst area of attack is in the erosion zone with a corrosion rate of 5 mils per year $(27 \mathrm{mdd})$ in this narrow region. The average corrosion rate over the entire pile surface is calculated to be 2.4 mils per year (13 mdd). The deepest pits developed between mean low water and the mud line as shown in the same figure. Photographs taken of the window in the atmospheric zone show considerable deterioration of the polyvinylidene chloride not only in the area immediately adjacent to the window, but also in other surrounding areas. Figure 45 is an example of this observation. The least amount of undercutting is observed in the tidal zone where damage extends $0.3 \mathrm{in}(0.8 \mathrm{~cm})$ beyond the window as shown in figure 46. Below the mud line, the 


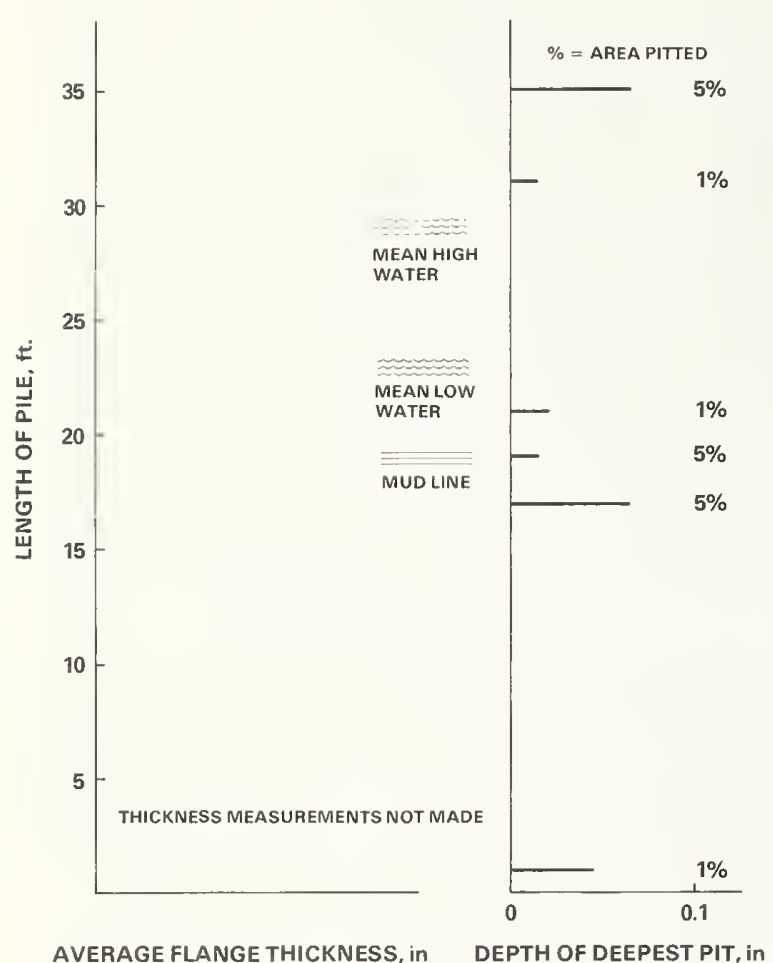

Figure 40

coating has been undercut almost two inches $(5 \mathrm{~cm})$ beyond the original edge of the window as shown in figure 47 .

Metal Pigmented Coatings-Two aluminum pigmented coal tar epoxy coating systems (Systems 8 and 9) were included in the investigation. The electrochemical measurements on these two piles are illustrated in figure 48 . From this figure one can see that the coating system on $8 \mathrm{~A}$ has a relative coating effectiveness of over 70 while system $9 \mathrm{~A}$ has slightly more than 60 . The electrical resistivity of these two metal filled coatings is so high, that for all practical purposes they are nonconducting in the voltage ranges of our experiments. This is an important consideration as any conductivity through the film will affect the electrochemical measurements as will be pointed out later. The flange thickness measurements for pile $8 \mathrm{~A}$ are illustrated in figure 49. This figure reveals that very little deterioration of the coating has taken place in the six years of exposure Most of the damage to the coating has occurred in the erosion zone. The corrosion rate in this region has averaged less than 0.1 mil per year $(0.5 \mathrm{mdd})$. The degree of pitting damage is

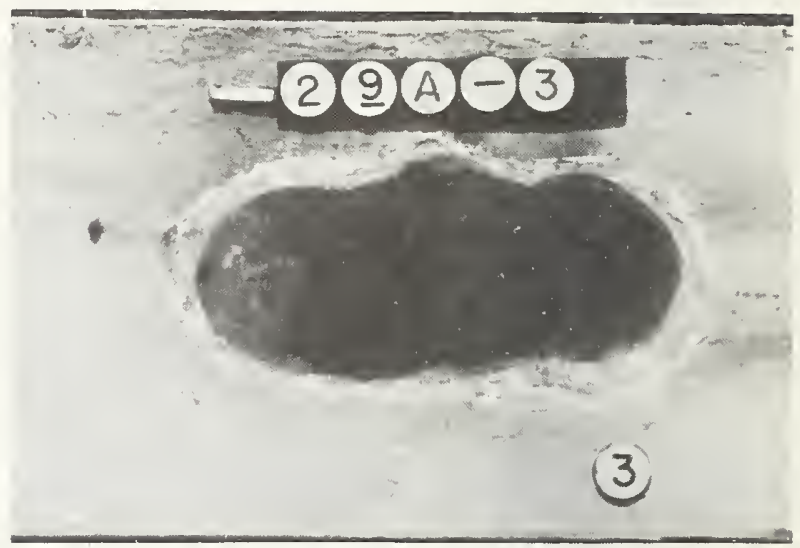

Figlie 1]

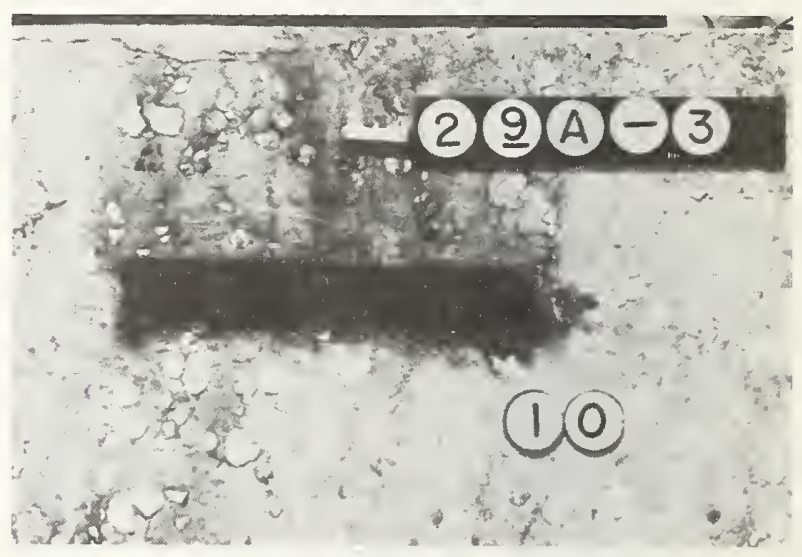

Figure 42

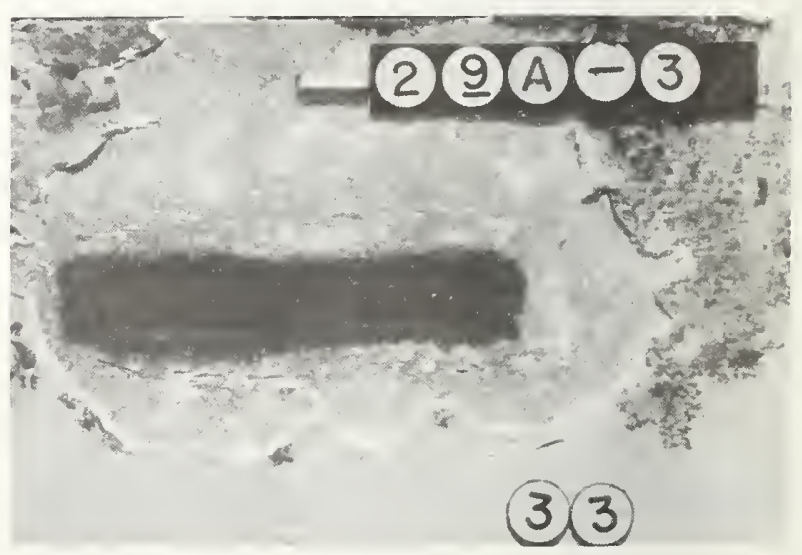

Figi Re 43

Flutieglass filled polyester 


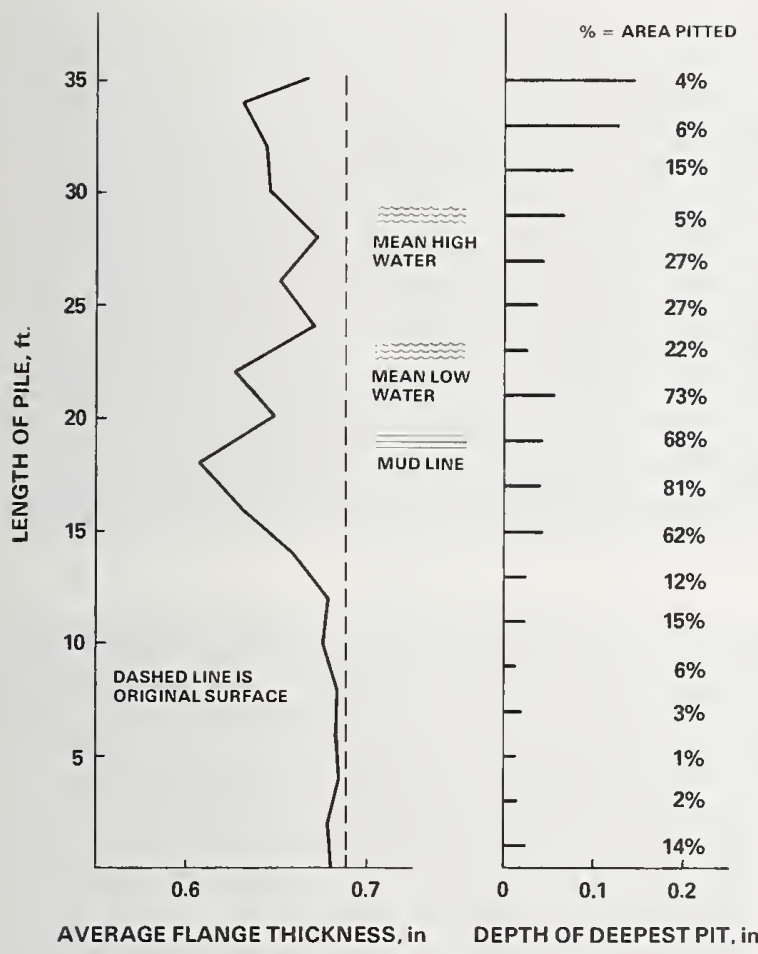

Figure 44

minor over most of the pile. In the atmospheric zone, undercutting of the coating extends less than 1.2 in $(3 \mathrm{~cm})$ beyond the original edge of the window as shown in figure 50 . The same figure shows the otherwise excellent condition of the coating in the surrounding area. Most of the apparent damage is rust staining. In the tidal zone the coating at the edge of the window is in fairly good condition with only $0.1 \mathrm{in}(0.2 \mathrm{~cm})$ of undercutting as seen in figure 51. Some coating damage is visible in the surrounding area. Figure 52 is a similar window below the mud line which displays essentially no undercutting and no coating deterioration in the visible area.

The second system of aluminum pigmented coal tar epoxy, System 9, has a film thickness that is 30 percent thinner than System 8 . Specimen 9A has undergone more damage as the physical measurements illustrate in figure 53. Incomplete sandblasting of the surface during the cleaning process has caused the flange of specimen $9 \mathrm{~A}$ in figure 53 to appear thicker in the erosion zone than it really is. The coating 1 in $(2.5 \mathrm{~cm})$ from the edge where the flange thickness measurements are made is in

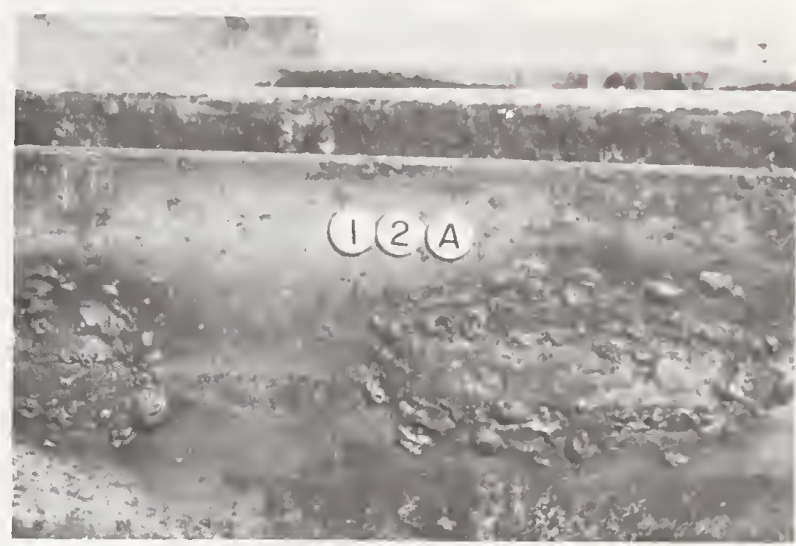

FIGURE 45

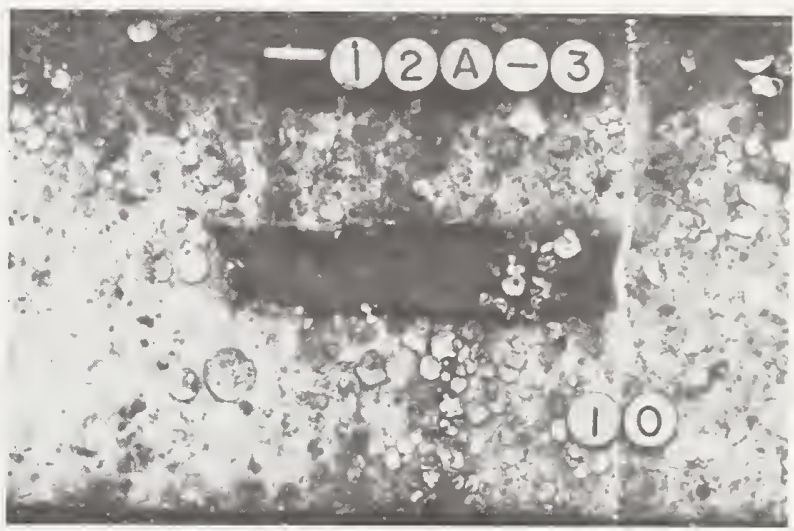

Figuhe 46

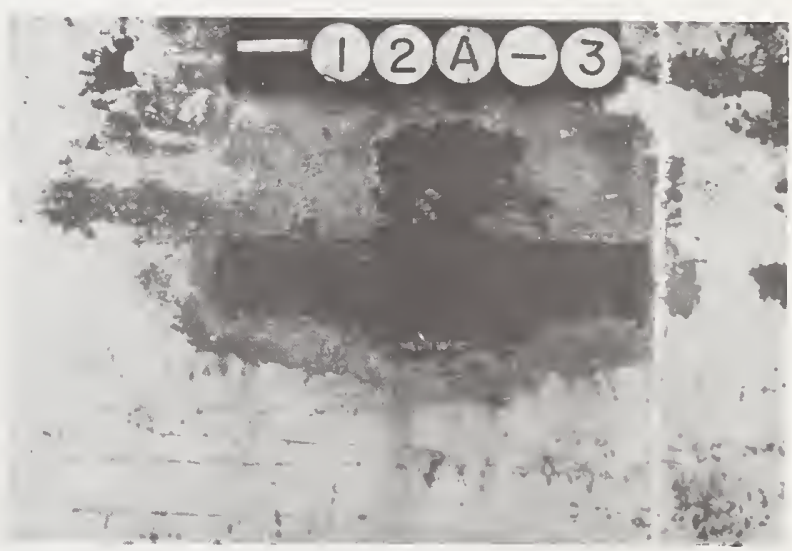

FIGURE 47

Polvringlidene chloride 


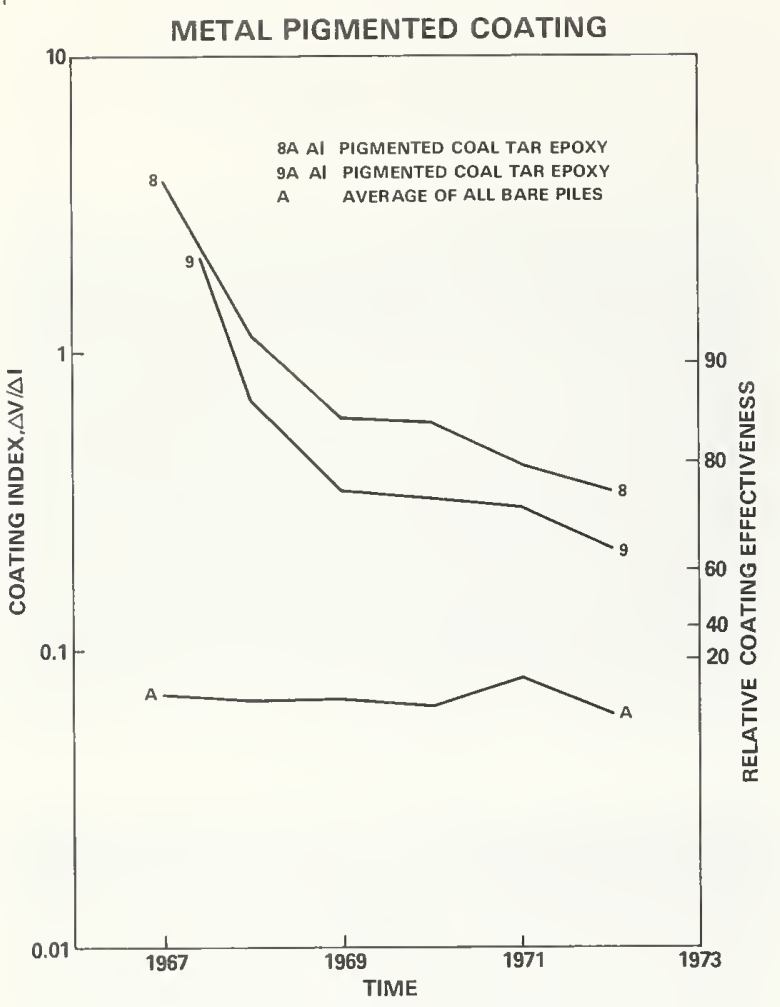

Figure 48

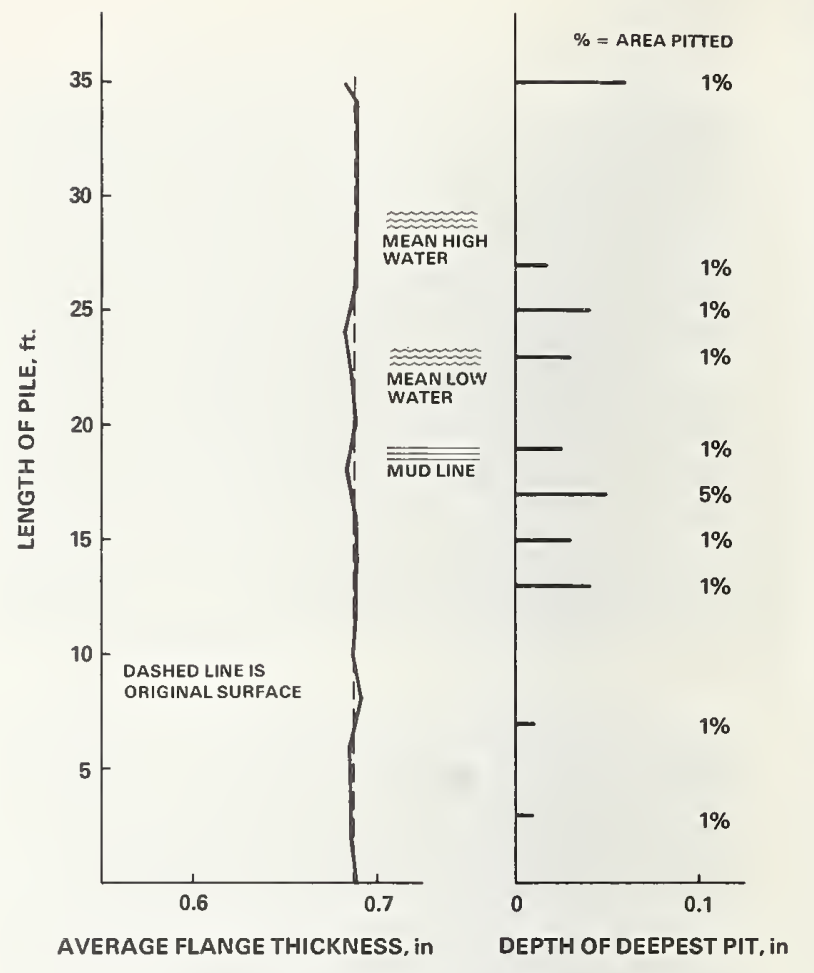

Figure 49 good condition, but two or three inches ( 5 to 7 $\mathrm{cm}$ ) from the edge, the coating had deteriorated as indicated by the pitting data in the same figure. The average corrosion rate over the entire surface of the pile is calculated to be sligthly less than 0.2 mils per year ( 1 mdd). In the atmospheric zone, the coating window has produced undercutting extending about 1.5 inches $(4 \mathrm{~cm})$ under the coat as seen in figure 54. In the tidal zone, coating damage at the window is minor as can be seen in figure 55 . Below the mud line undercutting has extended as much as 2 in $(5 \mathrm{~cm})$ under the paint system as shown in figure 56. Coating breakdown at the edge of the flange is also visible in this photograph. In general, both aluminum pigmented coal tar epoxy substrates have performed fairly well, although the thicker film, System $8 \mathrm{~A}$, has performed somewhat better in the six years of exposure.

Nonmetallic Coatings on Metal Filled Coatings-Metallic Zinc powder has been used in the metal filled undercoats of the five 2-coat systems discussed here. Whereas all of the topcoats are electrically isulating, three of the five metal filled undercoatings are electrically conducting. These three, Systems 18, 20, and 21 will be considered separately from the rest Figure 57 is a plot of the electrochemical data of these coatings. System 18, coal tar epoxy over zinc rich organic primer, is maintaining a relative coating effectiveness of 85 . At the same time System 20, epoxy polyamide over zinc rich inorganic primer, has a relative coating effectiveness of 80 . The coal tar epoxy over zine rich inorganic primer, System 21, also has a relative coating effectiveness of 85 . The relative coating effectiveness of these three systems may actually be slightly better than indicated by the electrochemical data. The reason being that as the overcoat erodes away or fails from some other cause, the electrically conducting metal filled undercoat is exposed. This undercoat may be protecting the steel very well, but because of its low electrical resistance it displays a lower coating effectiveness (coating index) than it really has.

The physical measurements on System 18A are illustrated in figure 58. The deterioration of the steel pile has been slight. The coating system has performed well in all of the zones of exposure. Average corrosion rate for the pile has been less than 0.2 mils per year ( 1 mdd). In the atmospheric zone, damage of the coating at the window has been severe as shown in figure 59. Undercutting of the coating extends almost 2 in $(5 \mathrm{~cm})$ beyond the window. Undercutting of the coating in the tidal zone has been 


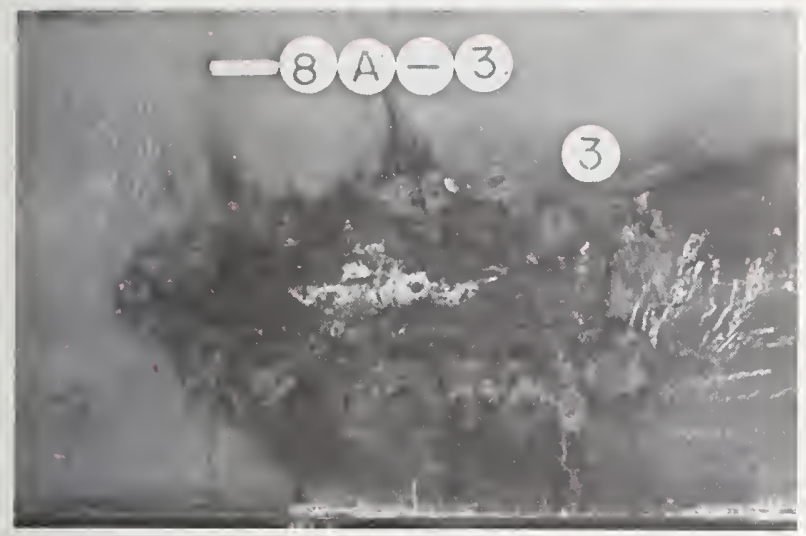

Figure: 50

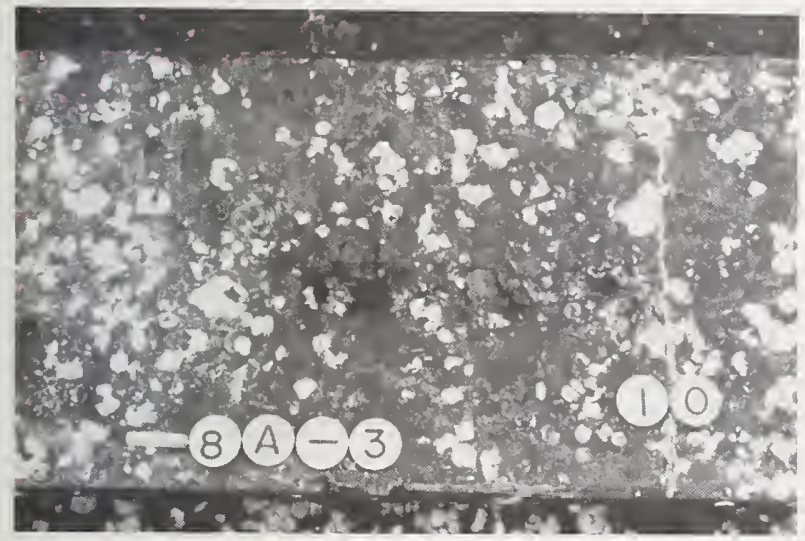

Figure 51

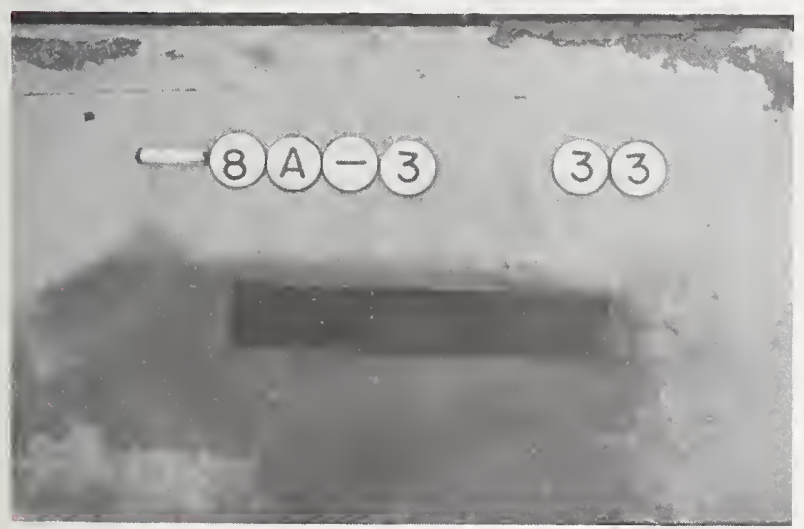

Figure 52

Aluminum pigmented coal tar epoxy minor as shown in figure 60. Below the mud line the effect is negligrible as seen in figure 61. Some of the coating damage visible in this photograph is mechanical abrasion due to removal and shipping.

System $20 \mathrm{~A}$ has also shown good resistance to the ocean exposure as illustrated by the physical measurements of figure 62. In this case some deteriolation has occurred at the elosion zone, but with insignificant attack below the mud line. The coating was not completely removed in some areas which accounts for the flange appearing thicker than it was originally. This certainly indicates that the coat was still protecting in these areas. The average corlosion rate for this pile was considerably less than $0.1 \mathrm{mil}$ per year $(0.5 \mathrm{mdd})$. Undercutting resistance has been very grood in all zones. The window located in the atmospheric zone developed less than 0.5 inches $(1.2$ $\mathrm{cm}$ ) of undercutting as shown in figure 63 . General pitting can be seen in the surrounding coating. Figure 64 illustrates the excellent appearance of the coating in the tidal zone. Below the mud line undercutting resistance is also very good, however, some blistering is visible in the coating in the adjacent areas (fig. 65).

System 21 has displayed unusually good resistance to deterioration in the offshore exposure as shown in the physical measurements of figure 66 . Incomplete sandblasting has led to the data showing the flange to be thicker than it was originally. As mentioned before, this clearly indicates that there was no metal loss in these areas. Thus, pile $21 \mathrm{~A}$ is in excellent condition after six years of exposure. The amount of pitting is minor as the same figure shows. Undercutting of the coating in the atmospheric zone has been moderate with damage extending about 0.6 in $(1.5 \mathrm{~cm})$ beyond the window as seen in figure 67 . The coating in the surrounding area is in excellent cordition. In the tidal zone undercutting is of minor consequence and extends less than 0.1 in $(0.2$ $\mathrm{cm}$ ) as illustrated in figure 68. Below the mud line there was no measurable undercutting of the coating as shown in figure 69. Mechanical damage to the edge has removed some of the coating.

Attention is again directed to figure 57 which illustrates the electrochemical data for the nonmetallic coatings on metal filled coatings. Systems 18, 20, and 21 have been described. The remaining systems in this category are piles $19 \mathrm{~A}$ (vinyl over zinc rich inorganic primer), and $22 \mathrm{~A}$ (vinvl mastic over zinc rich inorganic primer).

The electrochemical data indicate that Systems 19 and 22 are very similar in their deterioration and degree of protection as figure 57 illustrates. The relative coating effectiveness 
9A AI PIGMENTED COAL TAR EPOXY

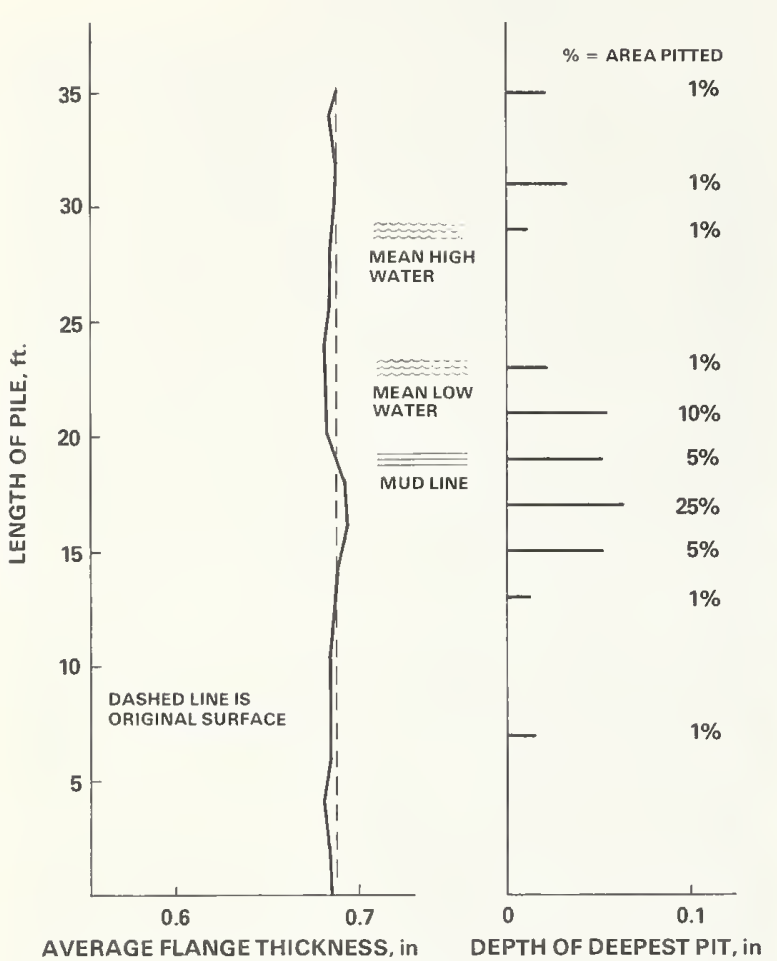

Fin. IR: $5 \%$

of both is slightly over 60 . The physical measurement data for pile $19 \mathrm{~A}$ is plotted in figure 70. Attack of the pile has been general over its length. However, there was more attack in the erosion zone than this data, taken 1 in $(2.5$ $\mathrm{cm})$ from the edge, indicates. The corrosion extended from the $15-\mathrm{ft}$ mark to the $20-\mathrm{ft}$ mark on the inner surface of the flanges and 2 to 3 in from the elge. This attack is indicated by the pit depth measurements of figure 70 . Its average corrosion rate is about 0.2 mils per year (1 mdd). Undercutting in the atmospheric zone shown in figure 71 extends less than 0.5 in $(1.2 \mathrm{~cm})$ beyond the window with some edge deterioration evident. General deterioration has been extensive in the tidal zone. Figure 72 is a photograph of the window in this region that reveals less than 0.1 in $(0.2 \mathrm{~cm})$ undercutting. Below the mud line undercutting was also less than 0.1 inches $(0.2 \mathrm{~cm})$ as shown in figure 73 . The coating was damaged mechanically, but no undercutting was found under the surrounding encrustation.

Pile $22 \mathrm{~A}$, vinyl mastic over inorganic zinc rich, has a relative coating effectiveness slightly above 60 after six vears. The flange thickness measurements are illustrated in figure 74 .

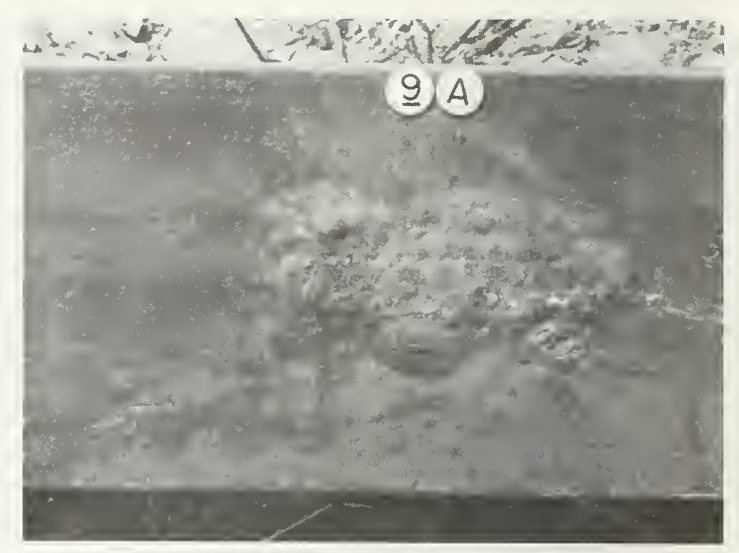

Figulie 54

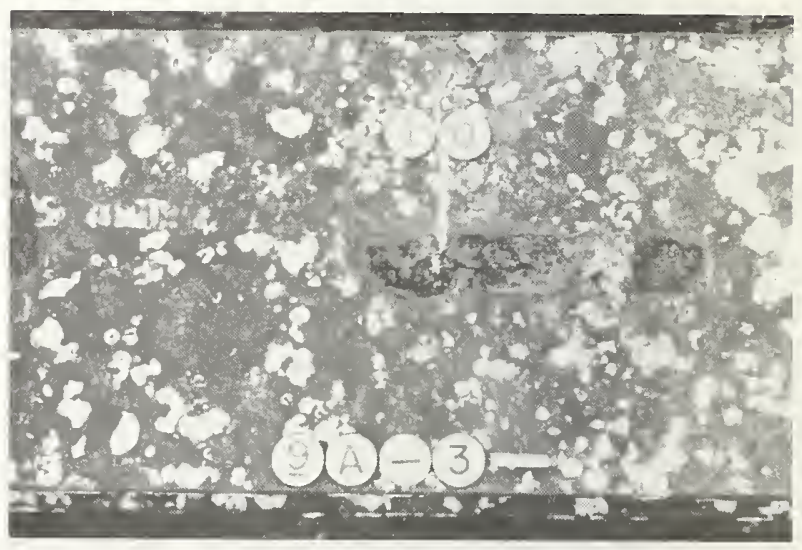

FIGURE 55

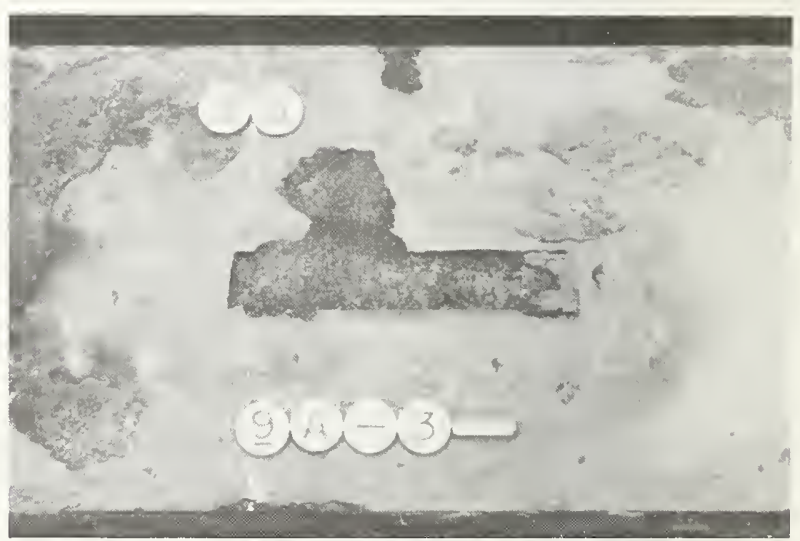

FHGU HE 56

fluminum pigmented roal tar epox! 


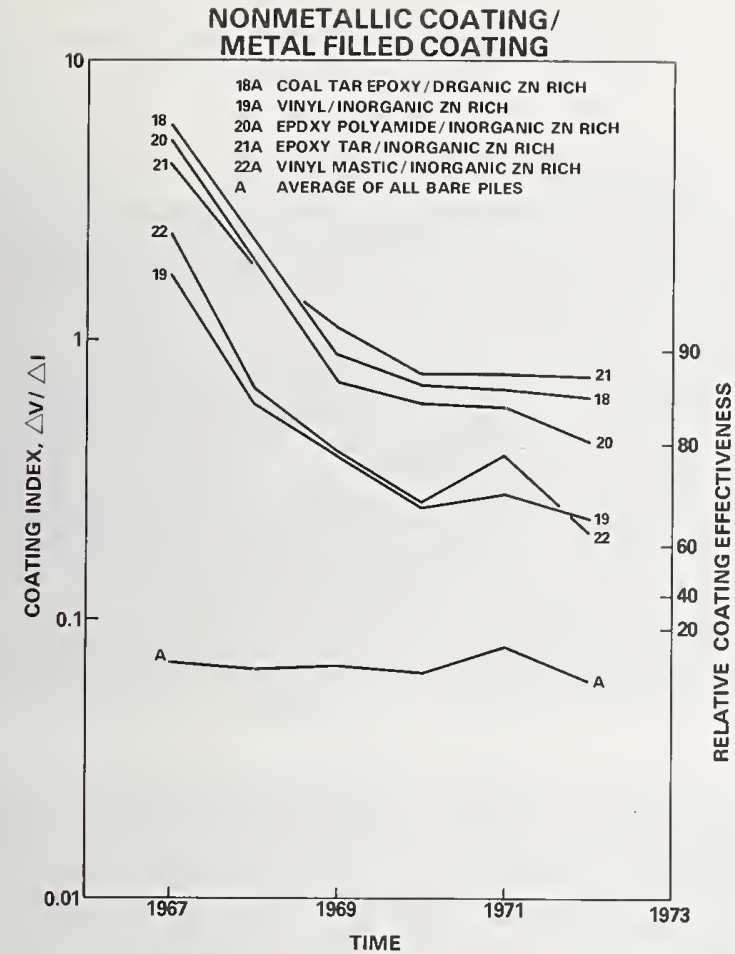

Figure 57

18A COAL TAR EPOXY / Zn RICH ORGANIC

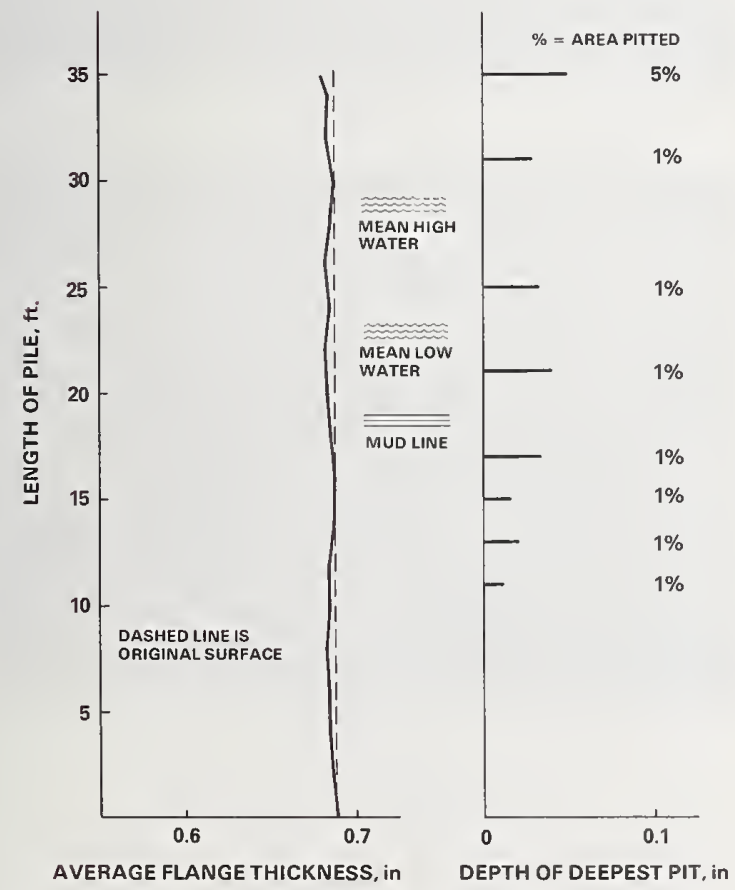

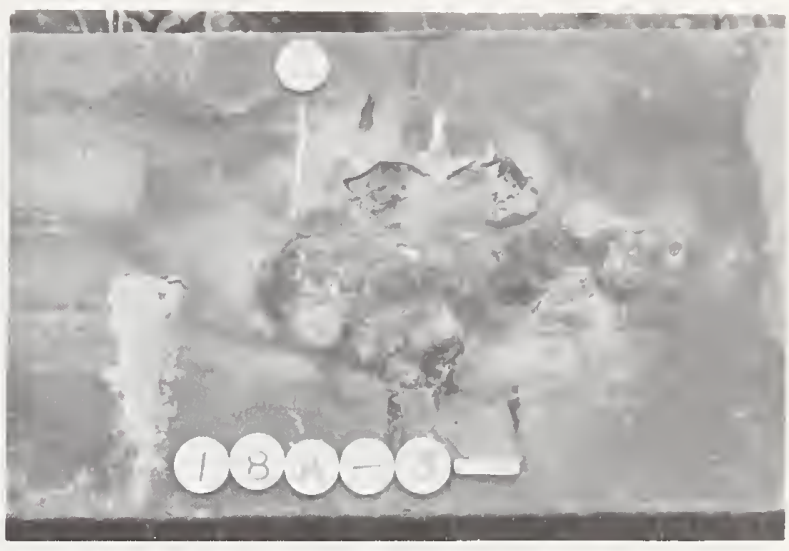

Figure 59

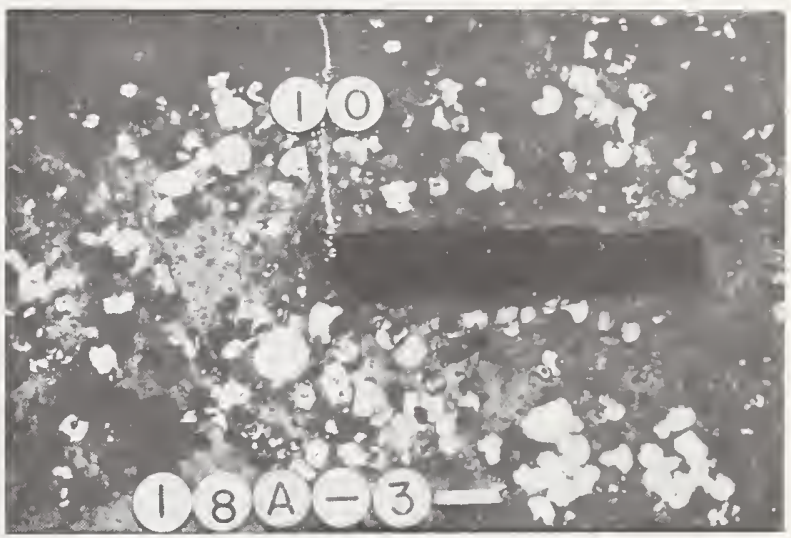

Figuhe 60

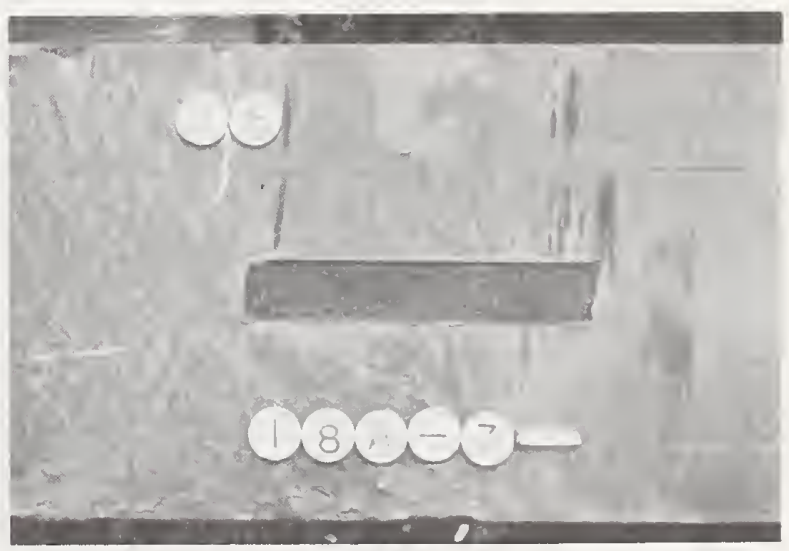

FigLRE 61

Coated zinc rich epoxy

Figure 58 


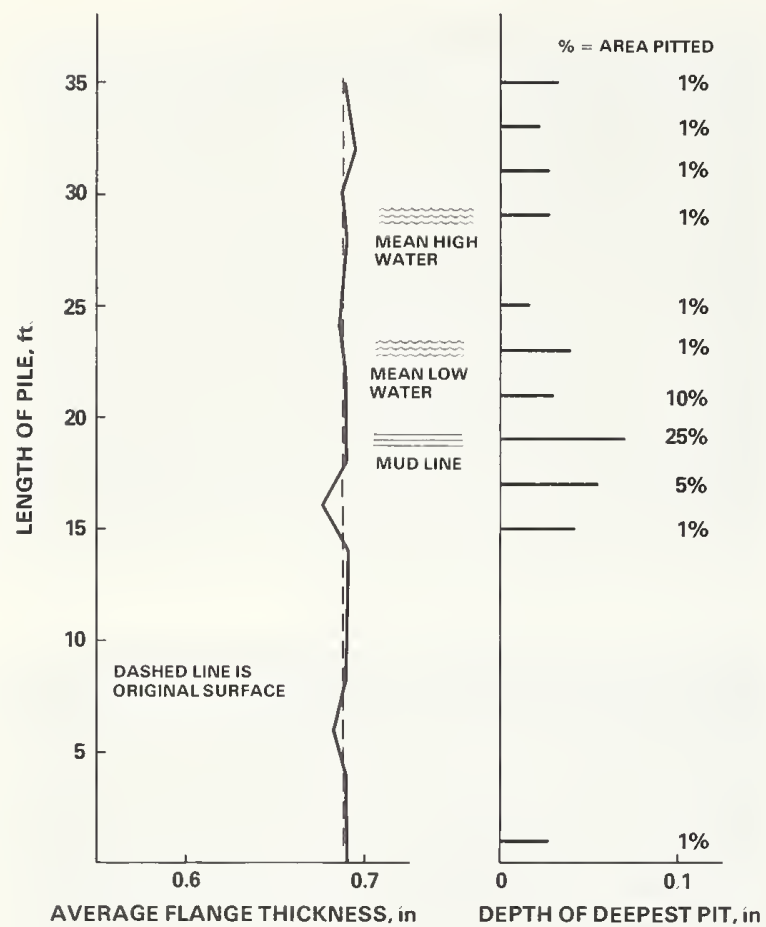

Figure 62

There is very little attack in the atmospheric zone. Undercutting in this area is less than 0.1 in $(0.2 \mathrm{~cm})$ as shown in figure 75 . In the tidal zone general deterioration of the coating has taken place, but with very little actual metal loss. This is illustrated in figure 76 . Undercutting here is also less than 0.1 in $(0.2 \mathrm{~cm})$. Below the mud line undercutting extends about 0.2 in $(0.5 \mathrm{~cm})$ beyond the window as figure 77 shows. Notice the blistering of the coating in the surrounding area. The overall average corrosion rate for pile $22 \mathrm{~A}$ is less than 0.25 mils per year (1.4 mdd).

In general, these two-coat systems, nonmetallic coatings over metal filled coatings, have performed very well with overall corrosion rates averaging less than 0.2 mil per year (1 mdd). The coal tar epoxy over inorganic zine rich, $21 \mathrm{~A}$, has shown above average resistance to the ocean environment in the six years of exposure.

Nonmetallic Coating on Metallic CoatingsThis group of coatings is made up of three systems: 13A, Vinyl sealer over flame sprayed aluminum, 15A, Polyvinylidene Chloride over flame sprayed zinc, and $16 \mathrm{~A}$, Vinyl-red lead over flame sprayed zinc. With these systems, as

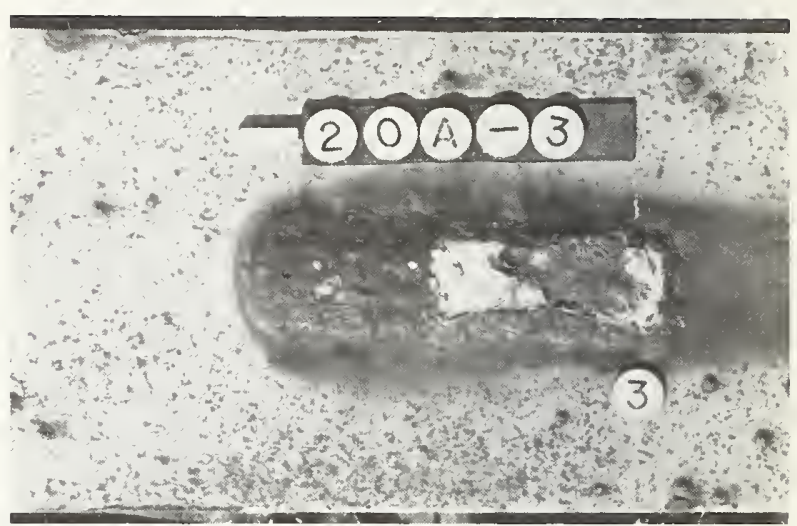

Figure 63

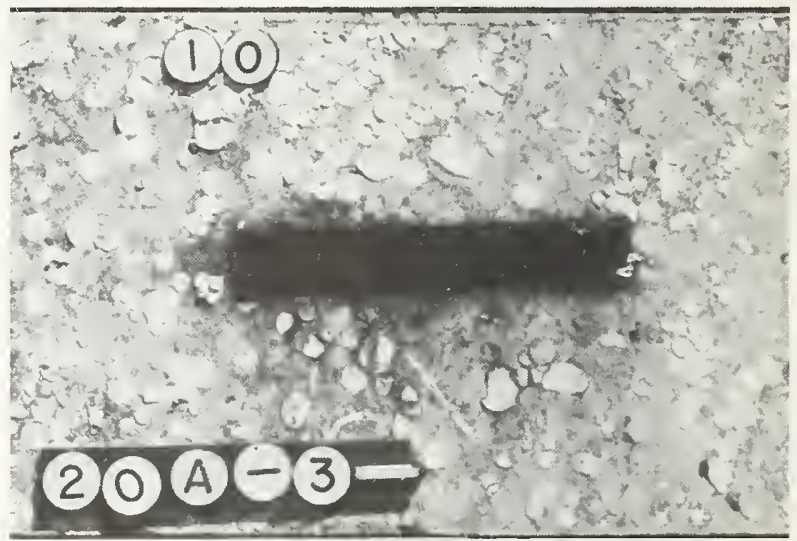

Figure 64

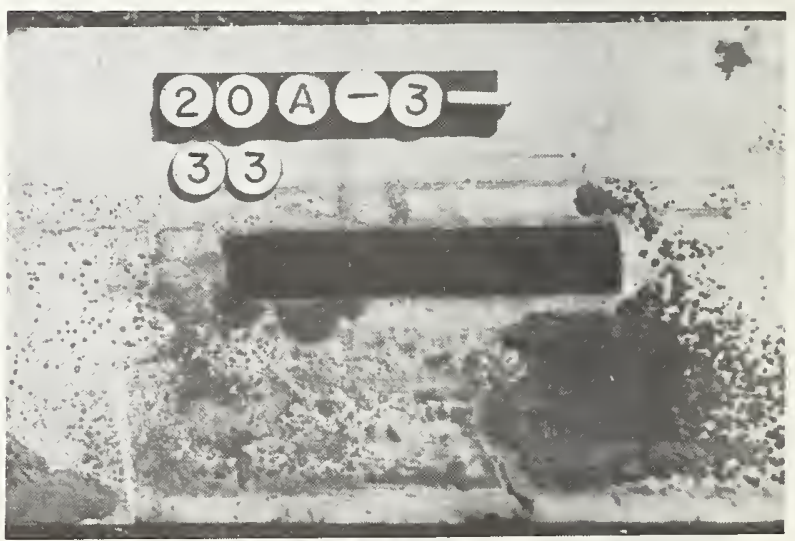

Figure 65

Coated zinc inorganic silicate 


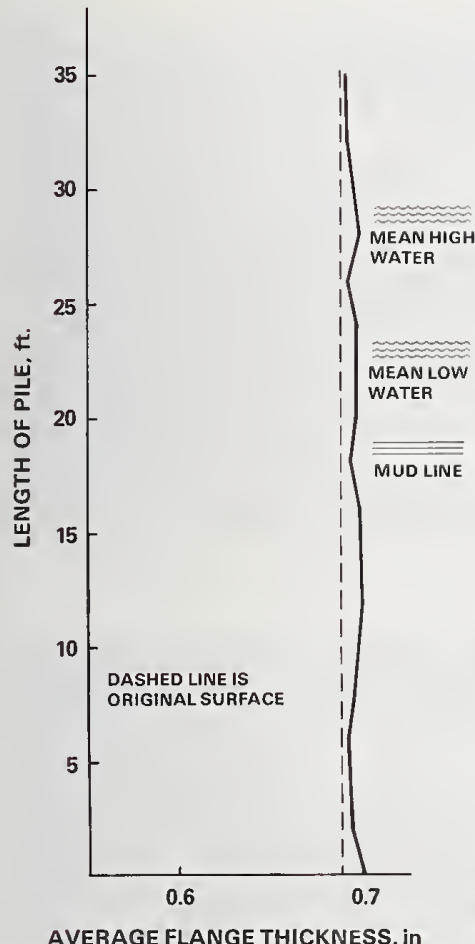

\section{Figure 66}

$\%=$ AREA PITTED

$1 \%$

$1 \%$

$1 \%$

$10 \%$

$10 \%$

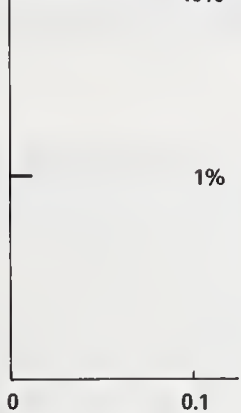

DEPTH OF DEEPEST PIT, in

with some of the electrically conducting metal filled coatings, the coating index (relative coating effectiveness) measurements are more complex. The electrochemical data still gives an excellent indication of the protective ability of the nonconducting top coat. Furthermore, as the top coat deteriorates the same data refiects the changes occurring on the metallic base coat. Figure 78 illustrates the electrochemical data gathered for the systems indicated. The vinyl sealer over flame sprayed aluminum system, pile $13 \mathrm{~A}$, now has a relative coating effectiveness above 60 . It is imporant to point out that the vinyl seals the pores of the flame sprayed aluminum and is not intended to form a continuous film over the surface of the aluminum. The flame sprayed aluminum coating, however, is still providing mechanical and electrochemical protection to the steel piling with the relative coating effectiveness being much better than that indicated by figure 78. Figure 79 illustrates the data on the physical measurements of this piling. Only a small amount of metal has been lost in the area of the erosion zone. The amount of pitting is practically insignifi cant. The average corrosion rate of $13 \mathrm{~A}$ has

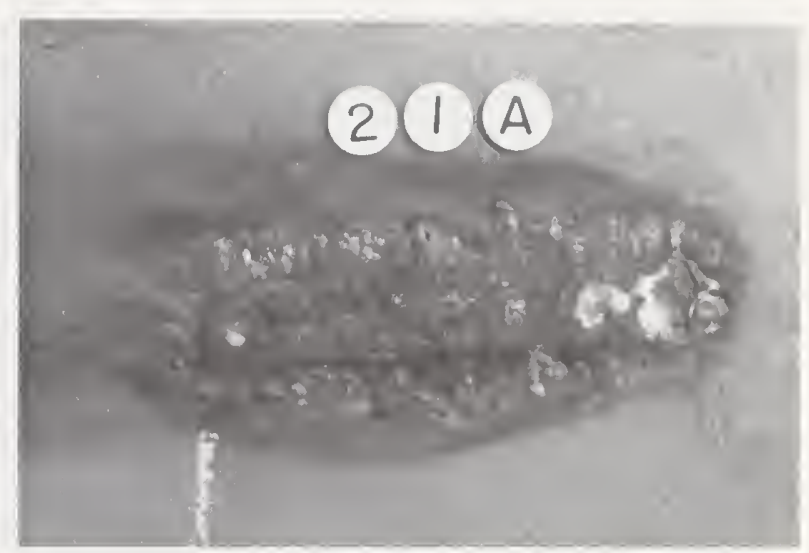

FugIRE: 67

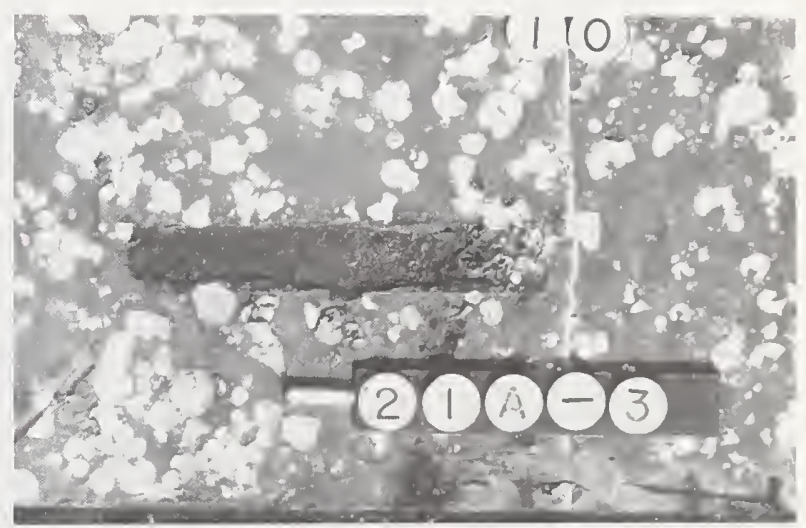

FIGIRE: 68

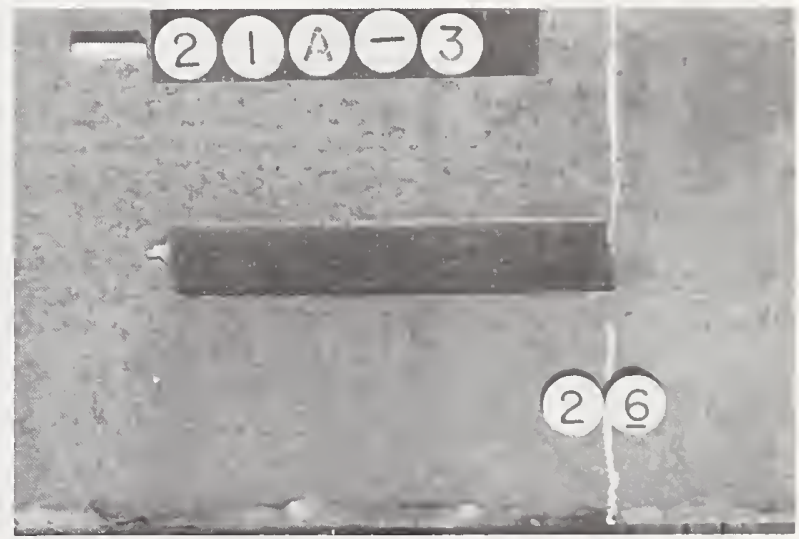

FIGI RE: 69

f.oated zine inoremic silicate 


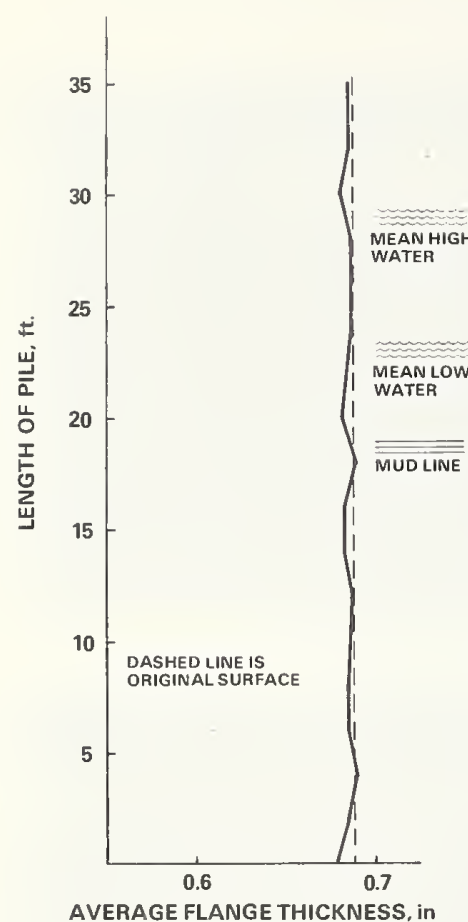

Figure 70

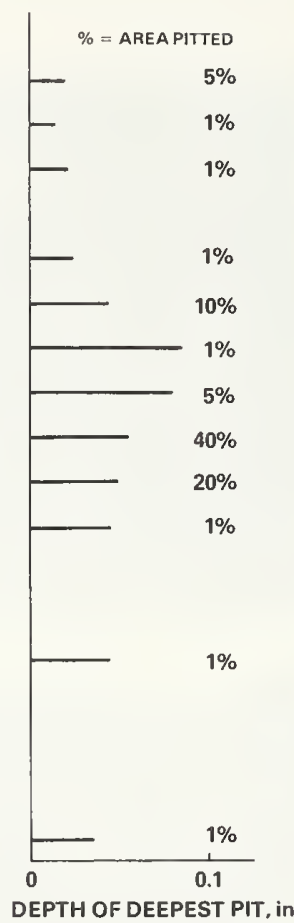

DEPTH OF DEEPEST PIT, in

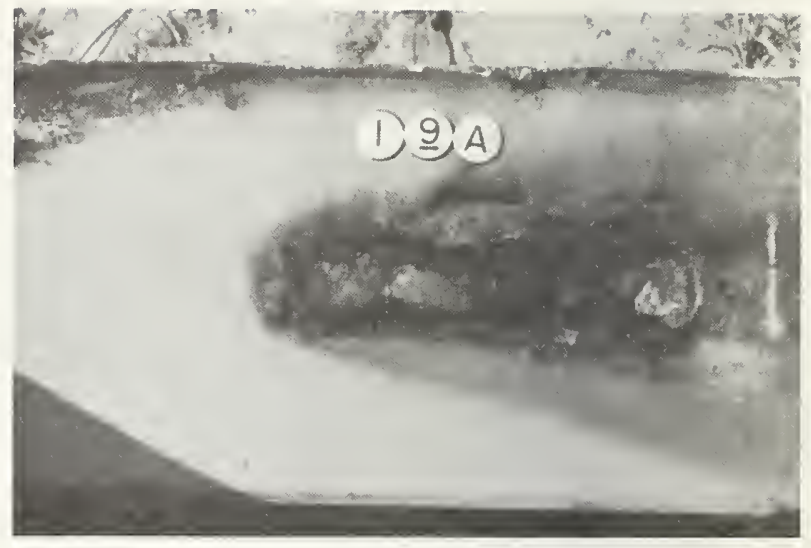

Figure 71

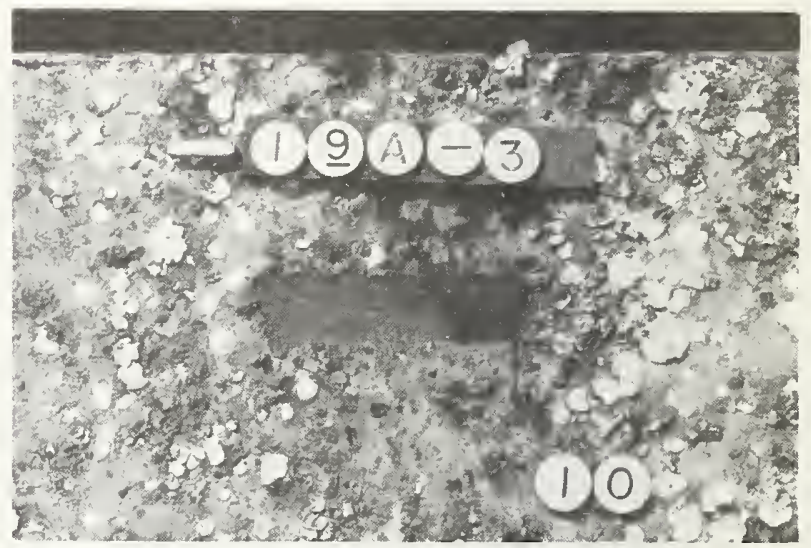

Figure 72

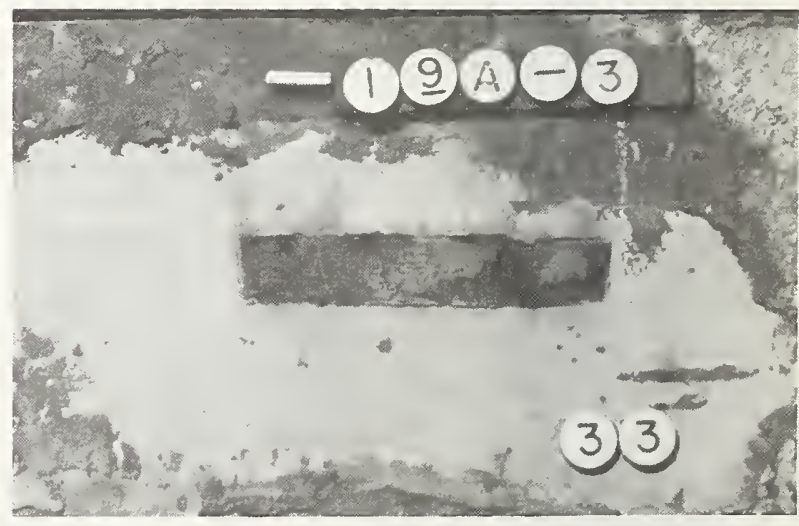

Fignle: 73

Coated zinr inorganir silicate 


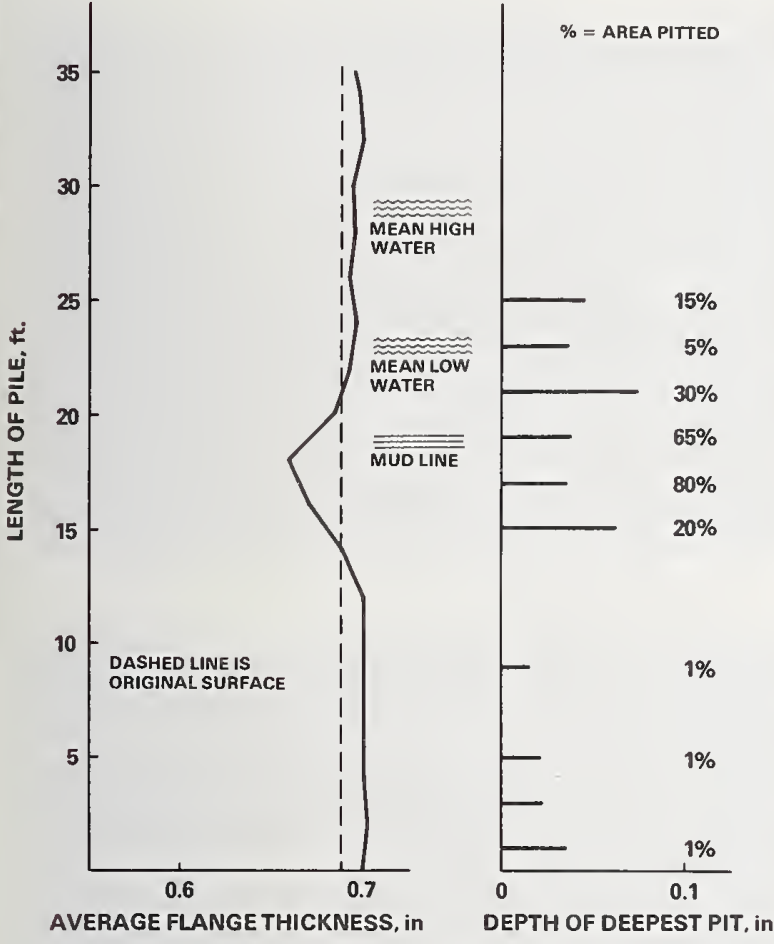

Figure 74

loss is small and uniform over the surface of the pile. Similarly, pitting is scattered and of minor consequence. The average corrosion rate for the entire pile is about 0.1 mil per year $(0.5 \mathrm{mdd})$. There were no windows in the coating of this pile. The following photographs are included to display its appearance in areas similar to those seen for the other pilings. The coating in the atmosphere is in very good condition with only minor damage in a few areas. Unfortunately the photograph of this area is of such poor quality that it will not be shown. In the tidal zone the nonmetallic coating is badly blistered as figure 84 shows, but the piling is still being protected by the zinc. Top coat blistering extends into the area below the mud line as figure 85 illustrates. but corrosion damage to the pile is minor.

The vinyl over zinc flame spray system, pile $16 \mathrm{~A}$, has undergone the most deterioration of the topcoated metallic coating systems. The relative coating effectiveness of $16 \mathrm{~A}$ is about 50 percent as figure 78 illustrates. After the top coat began to fail during the first year of exposure, the flame sprayed zinc protected the piling for a short period. Soon after, however, the system started to deteriorate steadily. It is of interest to note that the total coating thick-

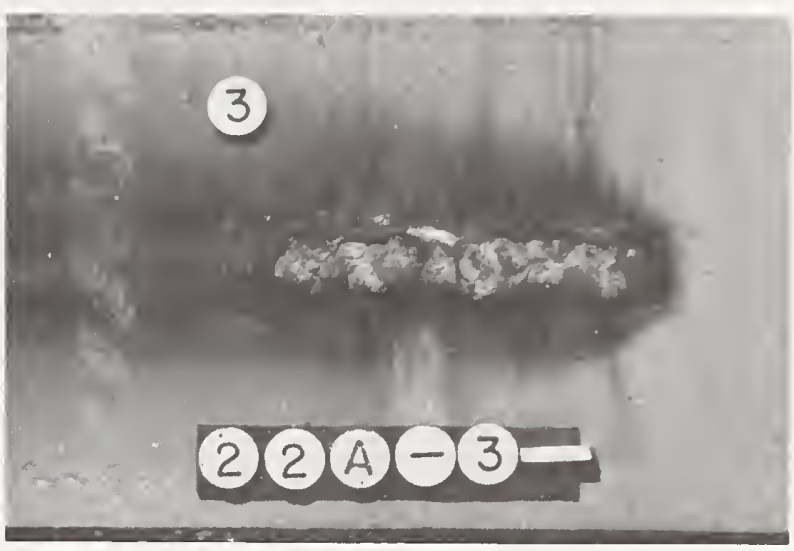

Figure 75

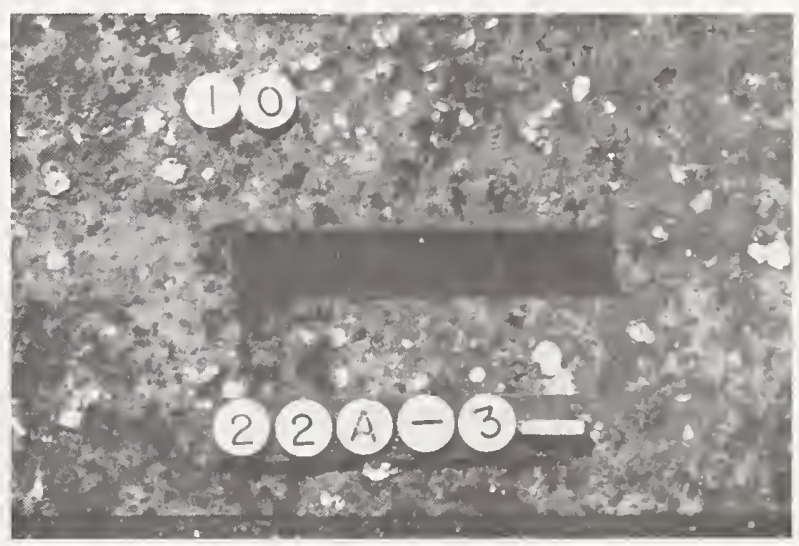

Figure 76

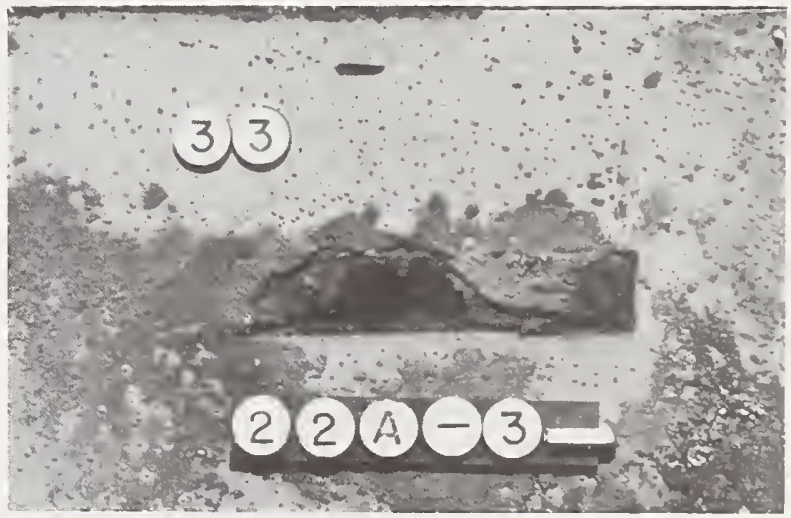

Figure 77

torted zine inorganic silicate 


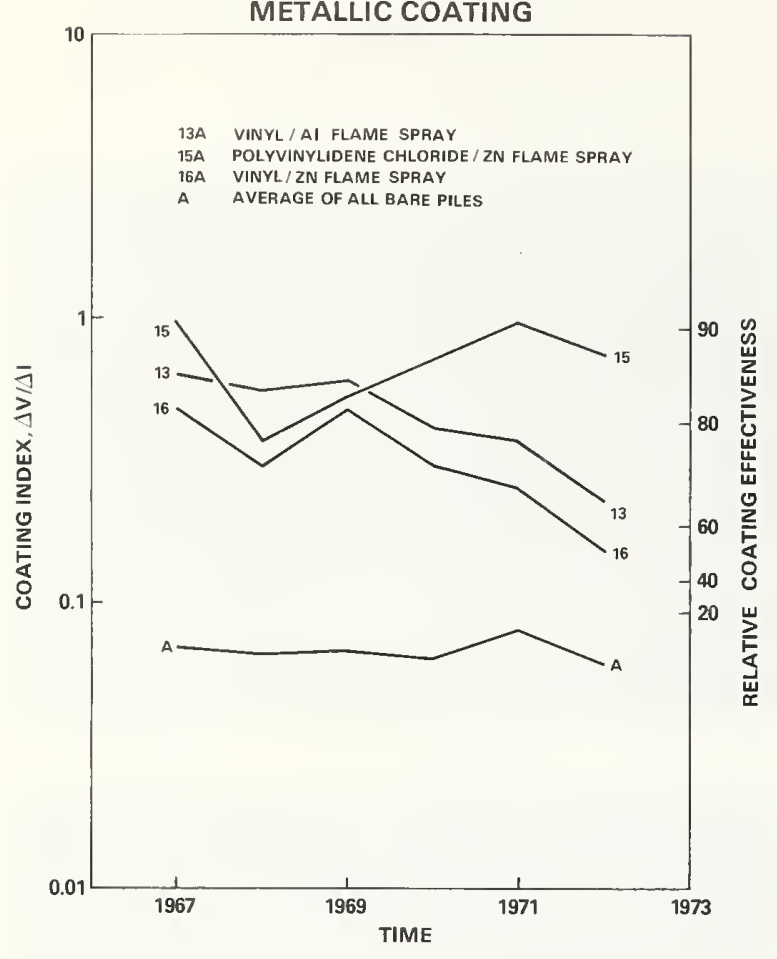

Figure 78
13A VINYL/AI FLAME SPRAY

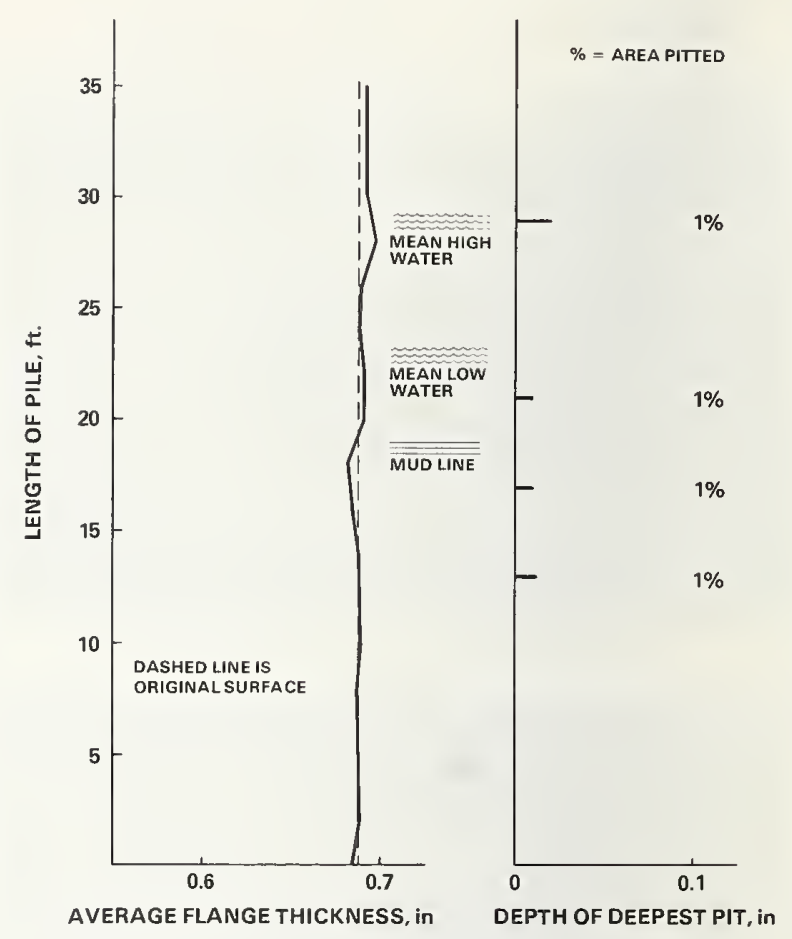

Figure 79

Corrosion rates for the nonferrous coatings cannot be calculated easily from the electrochemical data because it is not known with any degree of certainty what fraction of the total corrosion current measured is due to the corrosion of the steel substrate and what fraction is due to the nonferrous coating. Therefore, the corrosion current density shown in figure 90 is reported for these highly conducting coatings rather than the coating index used for the nonconducting coatings.

The results on the bare carbon steel piles are shown for reference as was done in all illustrations of electrochemical data. The corrosion current indicates that the bare steel corroded at a relatively uniform rate with time while the corrosion of the galvanized pile, $10 \mathrm{~A}$, has changed considerably in the same period. During the first three years, the corrosion current decreases by a factor of ten. Thereafter it increased steadily until now, eight years later, it is approaching the corrosion of the bare carbon steel pile. This data on the galvanized steel is made up of information from piles $A, B$, and $C$, two of which are still at the offshore site. Figure 91 illustrates the physical measurements on pile $10 \mathrm{~A}$. The pile shows some 


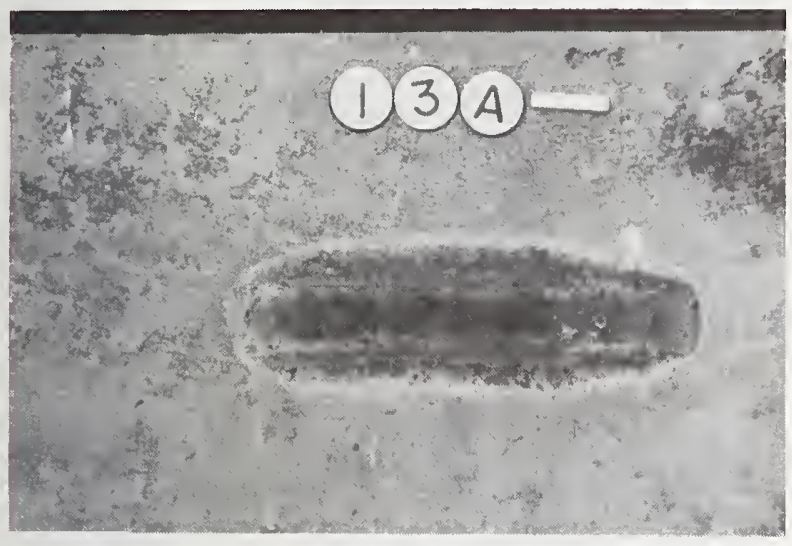

Fig, RF, 80

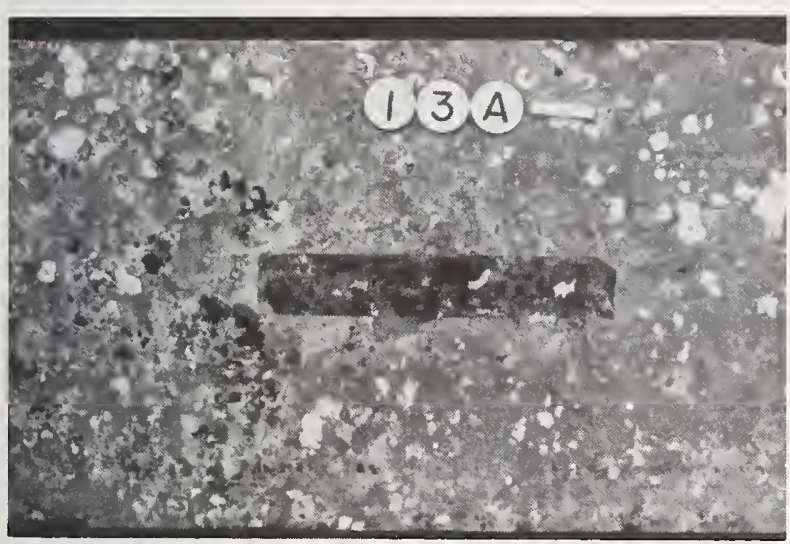

FIGL RE 81

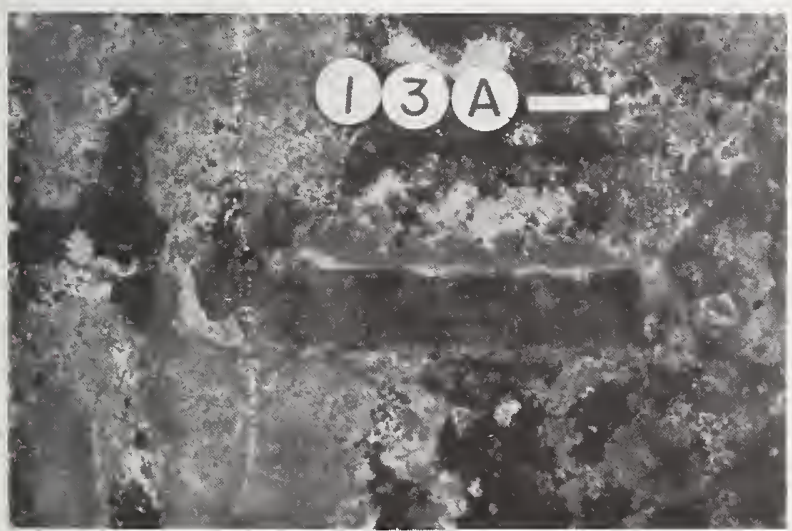

Figt Re 82

Flamesprayed aluminum wire corrosion in the atmospheric zone and con siderable corrosion in the abrasion zone. The average corrosion rate for the pile is less than 0.15 mils per year $(0.8$ mdd $)$. There are no windows in this system, but photographs are included for information. Above the high water line, coating failure is in the form of pits as figure 92 illustrates. In the tidal zone pitting continues along with some undercutting of the coating. A small section of coating was easily separated from the substrate as figure 93 shows. Below the mud line the coating was very thin or altogether missing in some areas as figure 94 illustrates.

The flame sprayed aluminum system, pile $14 \mathrm{~A}$, is similar to pile $10 \mathrm{~A}$ in its electrochemical behavior as indicated in figure 90. It too shows an increase in corrosion which is approaching that of bare steel as the aluminum deteriorates. The flange thickness measurements, figure 95, reveal some metal loss in the erosion zone, and practically no pitting anywhere. In the atmospheric zone the aluminum flame spray coating appears in excellent condition with the exception of the corrosion damage extending almost 1 in $(2.5 \mathrm{~cm})$ from the window shown in figure 96. In the tidal zone the coating is also in excellent condition (fig. 97) with minor damage extending from the window. From the mud line down, however, damage is more extensive. Figure 98 illustrates the window in this region with coating damage over most of the visible surface.

The metallic coatings began to show signs of deterioration after approximately five years of exposure. The steel piles that they protected are in excellent condition with minor damage in the abrasion zone.

Cathodically Protected Piles-The potentials of the cathodically protected piles over an eight year period are presented in table 2. Although the potentials of the steel piles versus a Ag$\mathrm{AgCl}$ half-cell and a $\mathrm{Cu}$-CuSO, half-cell were both measured, only the potentials versus $\mathrm{Cu}-\mathrm{CuSO}$, half-cell are indicated. In general, the potentials of the piles with anodes in the sand were less negative (more noble) during the eight year period than those piles with their anodes in the water. After one year, the potentials of the bare steel piles with aluminum

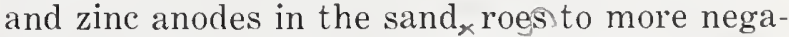
tive values which then remained rather constant during the eight year period.

The average corrosion current densities of several bare steel piles and the average protective current densities of steel piles with zinc anodes are plotted in figure 99. The protective current density of the protected piles represent both the galvanic current as well as local action culrent on the anodes. The local action curlent was not directly deternined but it has 
15A POLYVINYLIDENE CHLORIDE/

ZINC FLAME SPRAY

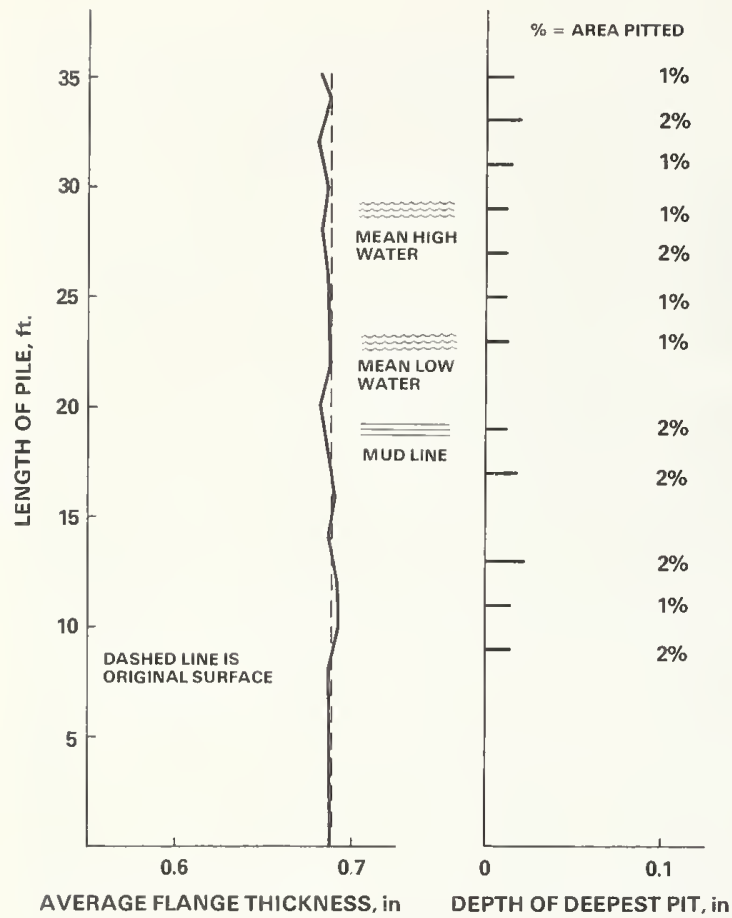

Figute 83

been estimated to be about 10 percent of the total corrosion current density [12]. The current density calculations were based upon the total submerged area of the pile. The areas of the anodes (originally $5-10 \%$ of the total submerged pile area) were not included in the calculations. Their consideration would have made the total protection current densities for the piles with anodes slightly less. These considerations apply to all of the systems to be discussed.

As seen in figure 99, the proteetive current densities of the zinc anode protected systems are less than those of the unprotected piles. It appears that there is not very much difference in the protective current densities provided by the anodes in the water and buried in the sand over the 6 year period (1970 to 1975). More time will be required to determine any real differences.

Aluminum anodes in the sand appear to be less effective than the anodes in water in protecting the steel (fig. 100).

In the case of mariner steel, however, the protection current density of the zinc anodes buried in the sand, over the 6 year period, is definitely less than the current density of the zinc anodes exposed to the water (fig. 101).

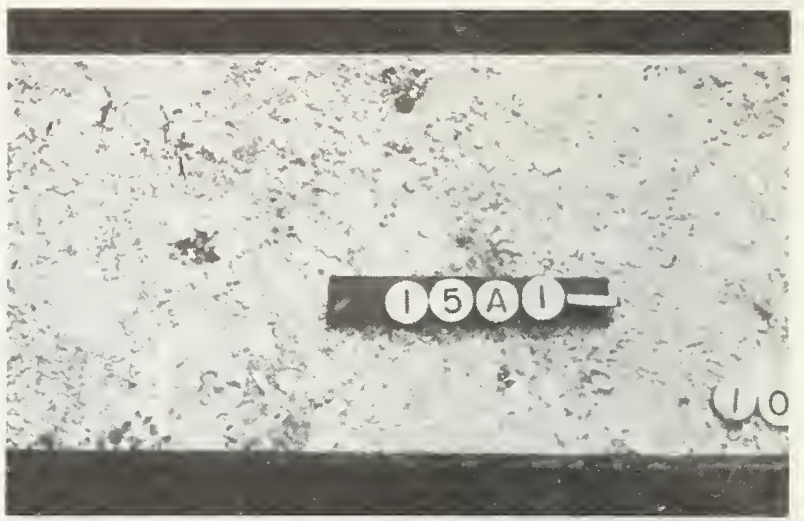

Figure 84
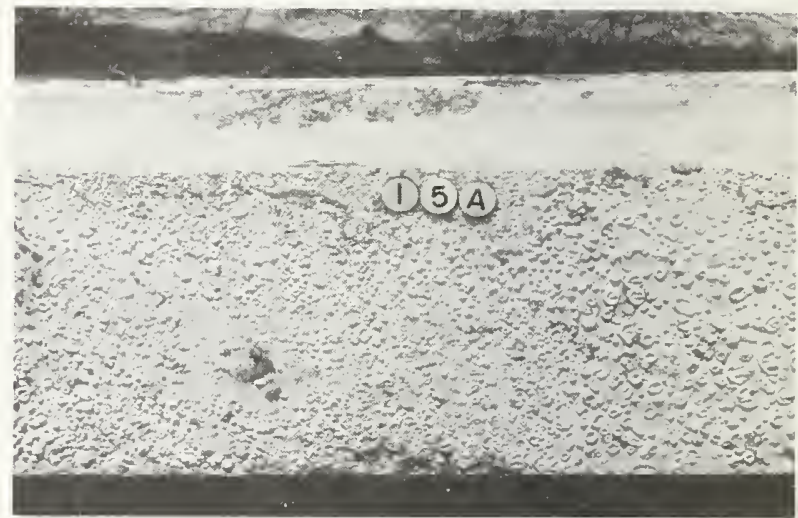

Figure 85

\section{Coated flamesprayed zinc}

The coal tar epoxy coated piles, with zinc anodes in the sand appear to be more effective (from a galvanic current standpoint) than the coated piles without cathodic protection except for one year (1971). For the piles with windows (5A and $25 \mathrm{~A}$ ), there was little discernible differences for two years $(1971,1972)$ between the piles with anodes in the water and the piles without anodes (fig. 102).

A comparison of the galvanized pile, with zinc anodes (System 11) and without zinc anodes (System 10), is shown in figure 103. Only a portion of the curve for the protective current density of the galvanized pile is shown. From 1973 to 1975 the curve represents the averages on piles B and C. Initially (1967) the average corrosion current density on piles $\mathrm{A}$, $\mathrm{B}$, and $\mathrm{C}$ was quite high and then decreased to very low values for 1967-1971 (fig. 90). The protective current density is very low for the zinc anodes buried in the sand and appears to be steadily decreasing with the passage of time. The protective current density for the zinc anodes in the water is about 3 times higher and appears to be increasing with time. 
16A VINYL/ ZN FLAME SPRAY

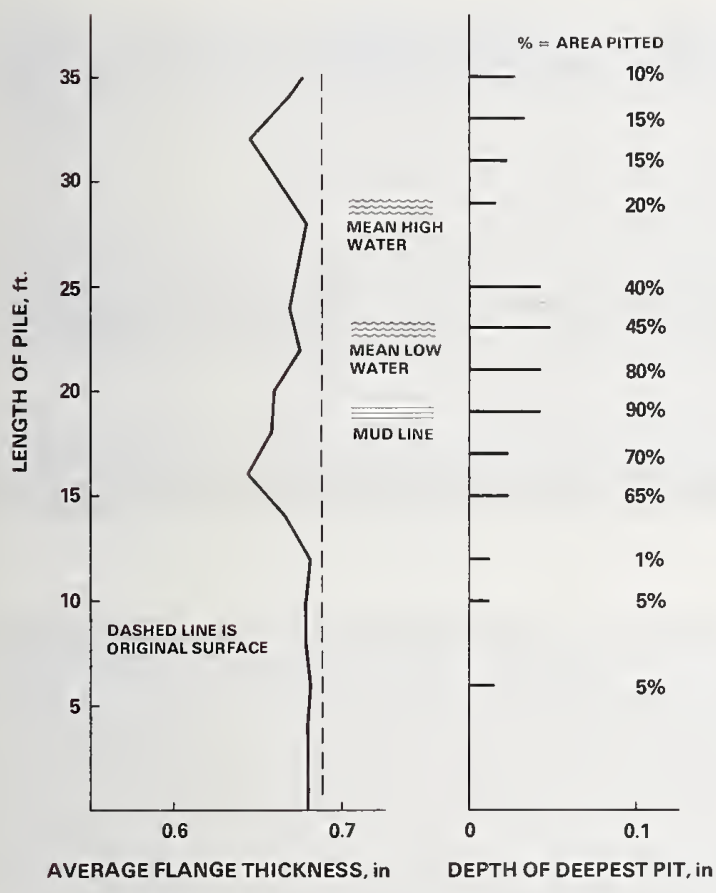

Figuke 86

\section{Summary}

Every coating system reduced the corrosion of the steel piling in seawater. In this respect they differed only in the degree of protection they afforded the steel. In the first six years of exposure some coatings reduced corrosion by a factor of 200 while others reduced corrosion by a factor of 2 as compared to the bare piles. In table 3 , the coatings are listed in order of increasing degree of corrosion of the piling. It is apparent from this table that there is no group of coatings (i.e., nonmetallic, metal pigmented, etc.) that is entirely satisfactory.

An average corrosion rate of $0.1 \mathrm{mpy}(0.5$ mdd) or less was measured for six systems. Four of these six are two-coat systems. Generally the two-coat systems performed very well in this program. The other two systems with average corrosion rates $<0.5 \mathrm{mpy}(0.5 \mathrm{mdd})$ are an aluminum pigmented coating, and a glass flake filled coating. Both performed very well with the glass flake filled coating being particularly resistant to the abrasive action of the erosion zone.

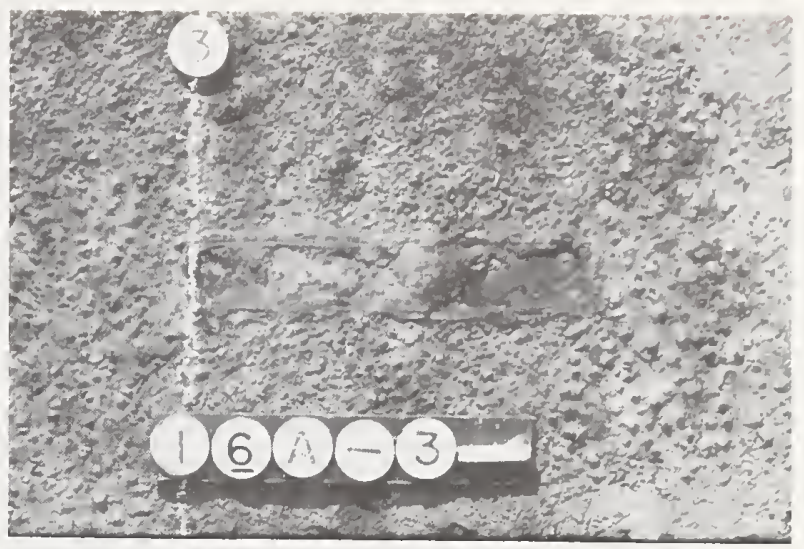

Figu hE: 87

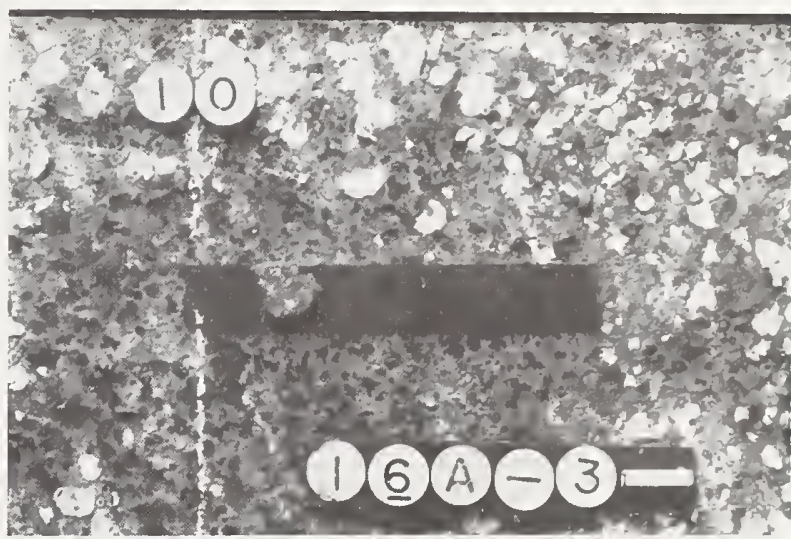

Figure 88

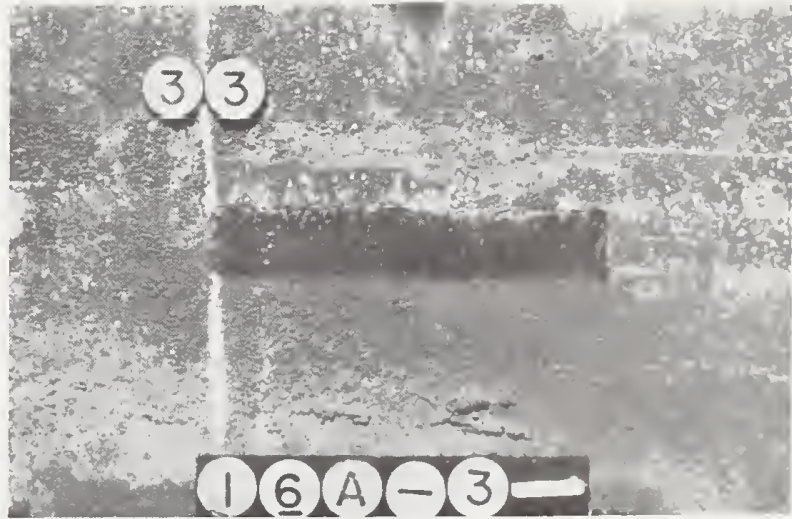

Figire 89

Couled famespraved zinc 


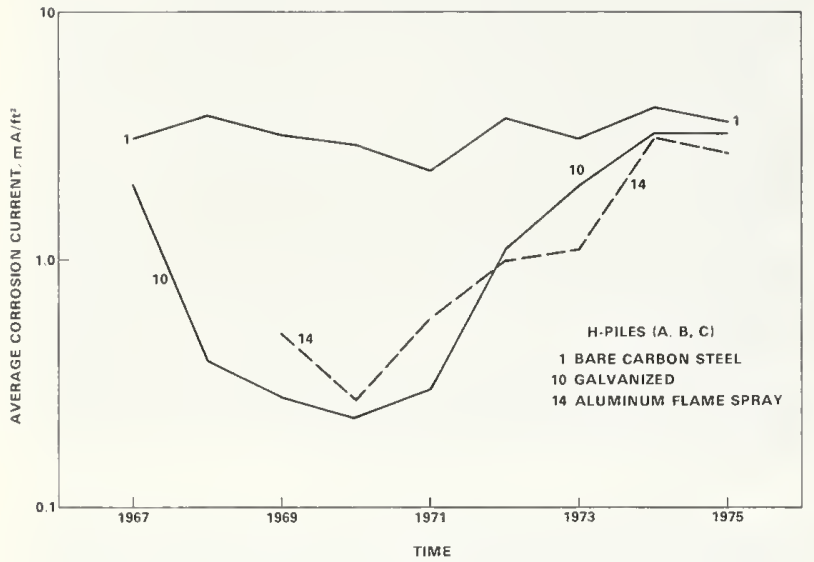

Figitre. 90

\section{A GALVANIZED}

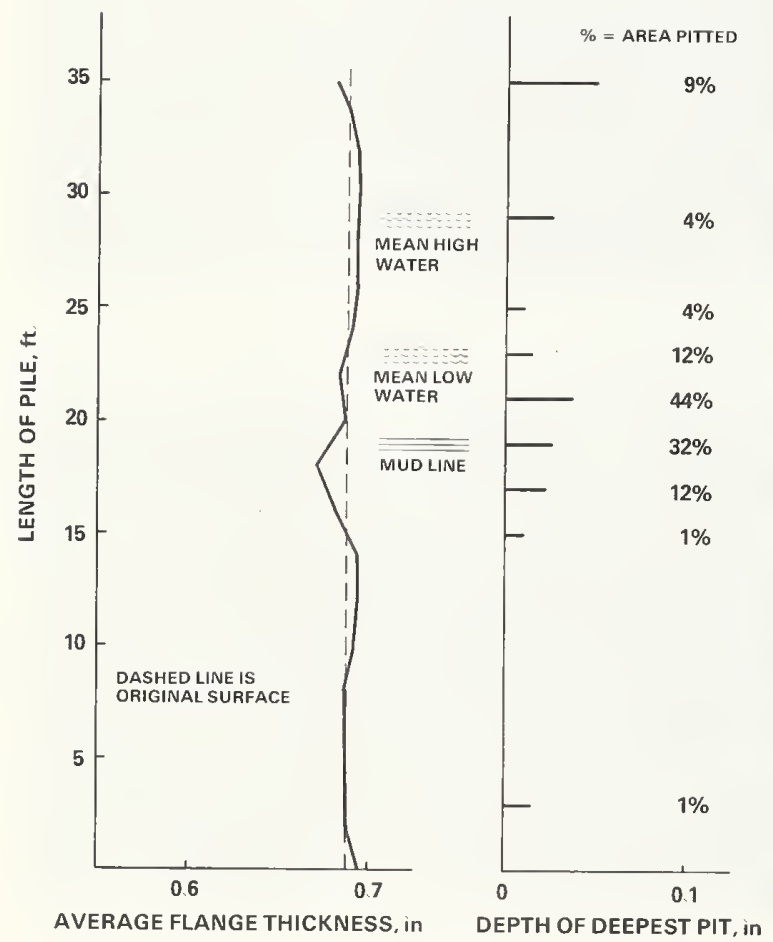

FigriRe 9$]$

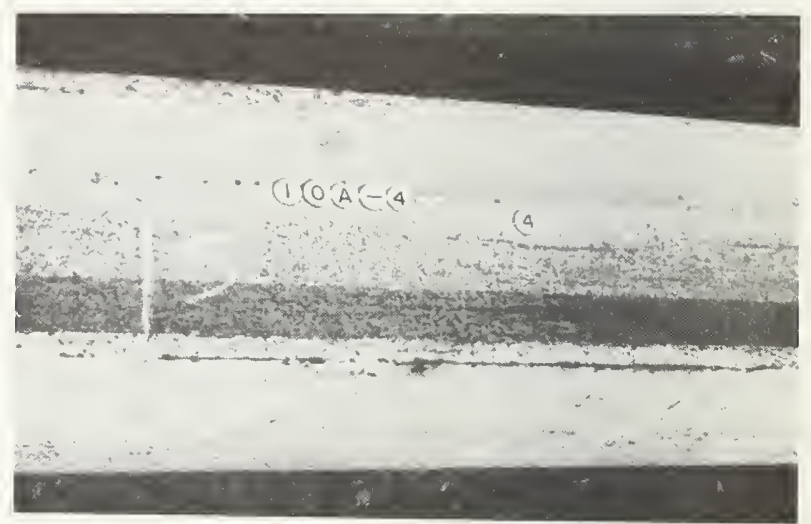

Figl RE 92

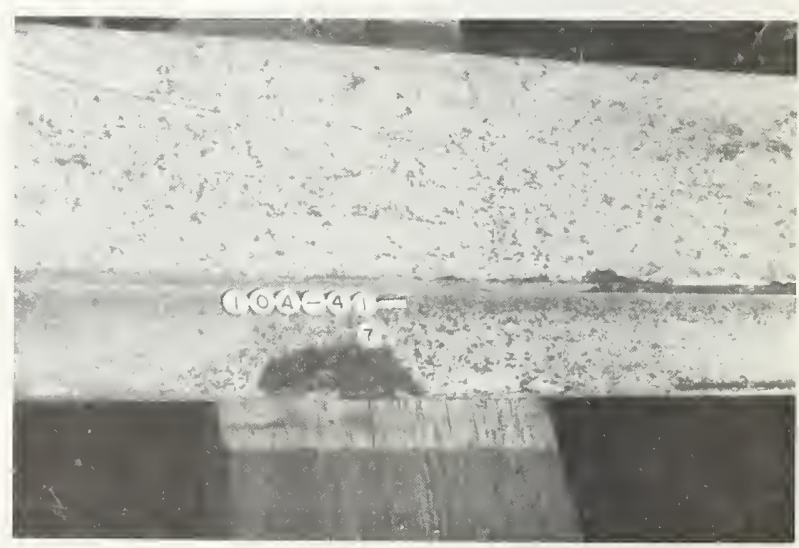

Figure 93

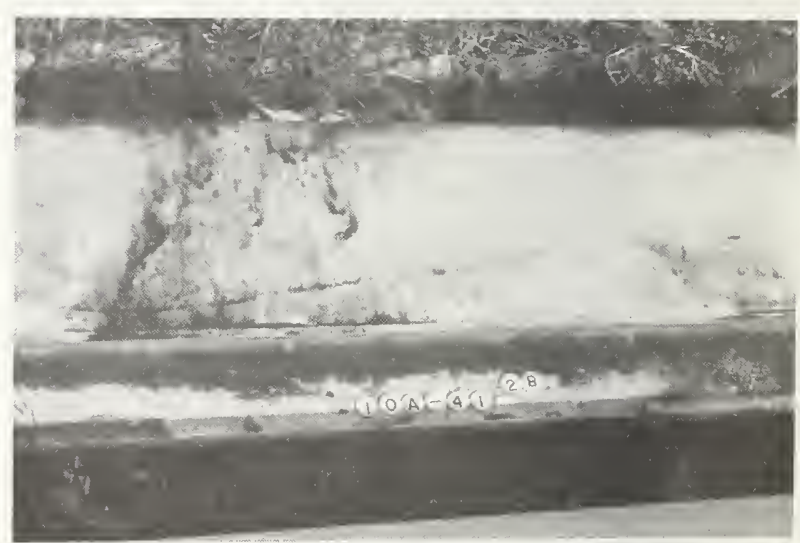

Figure 94

Hor dipped zine (galvanized) 


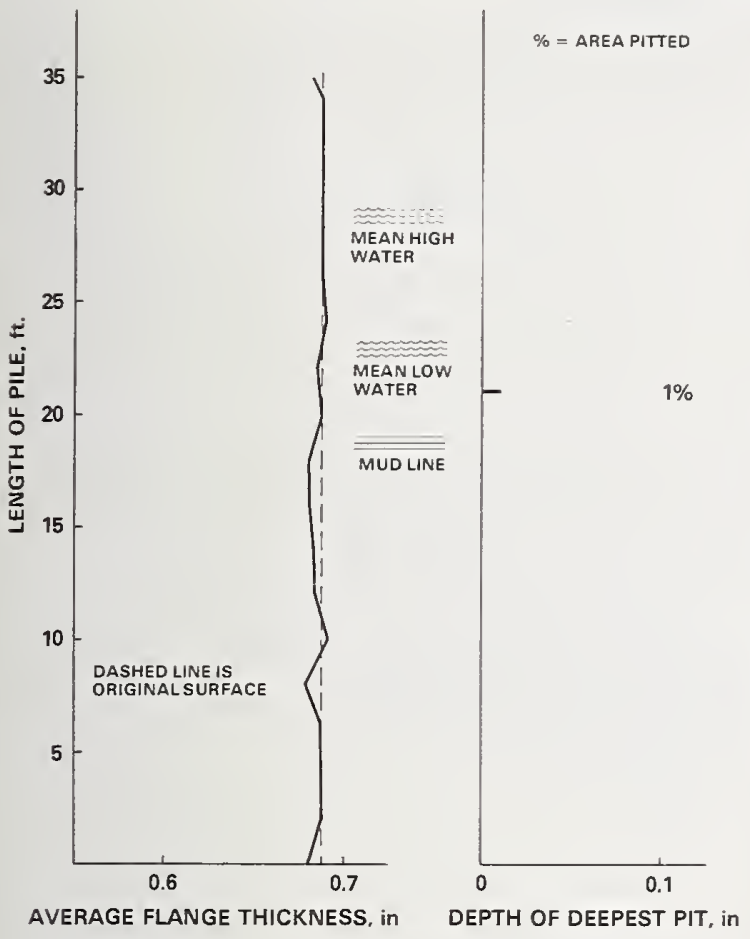

Figlhe 95

Seven systems exhibited corrosion rates in the range of $0.14 \mathrm{mpy}(0.8 \mathrm{mdd})$ to $0.24 \mathrm{mpy}$ ( $1.3 \mathrm{mdd}$ ) as table 3 reveals. All seven of these coatings performed well. Two are metallic coatings that were distinctive in their ability to protect the piling uniformly including the corners of the flange. Most coatings first failed at the corners. System 22 suffered extensive breakdown in the erosion zone but unusually good resistance to attack in the atmosphericsplash zone.

The remaining six systems were the least protective with average corrosion rates on the steel greater than 0.53 mpy ( 3 mdd). Four of the six systems are coal tai epoxy coatings which were particularly poor in the atmospheric-splash zone leading to relatively high average corrosion for the steel. Of all the coatings, System 12 provided the least protection to the steel, even though it has been reported to perform well by other laboratories [7].

As expected, the electrochemical measurements of the cathodically protected systems clearly indicate that their corrosion rates are much lower than similar piles without protection. Furthermore, it is of interest to note that,

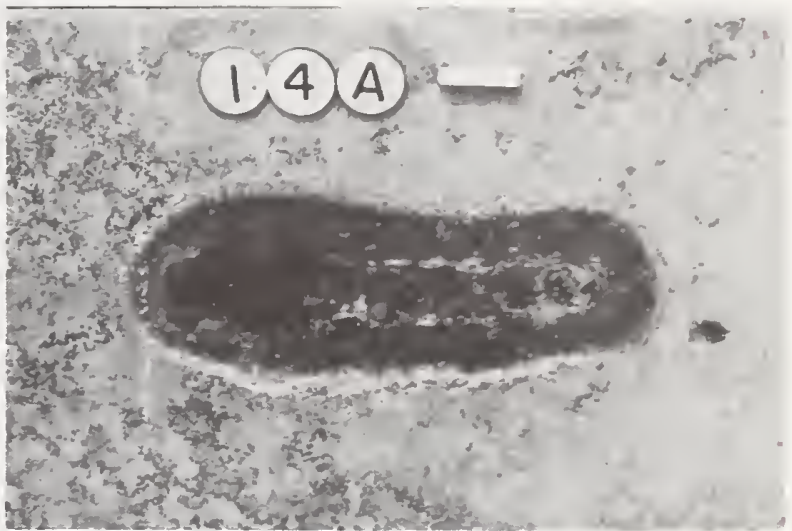

FigC he 96

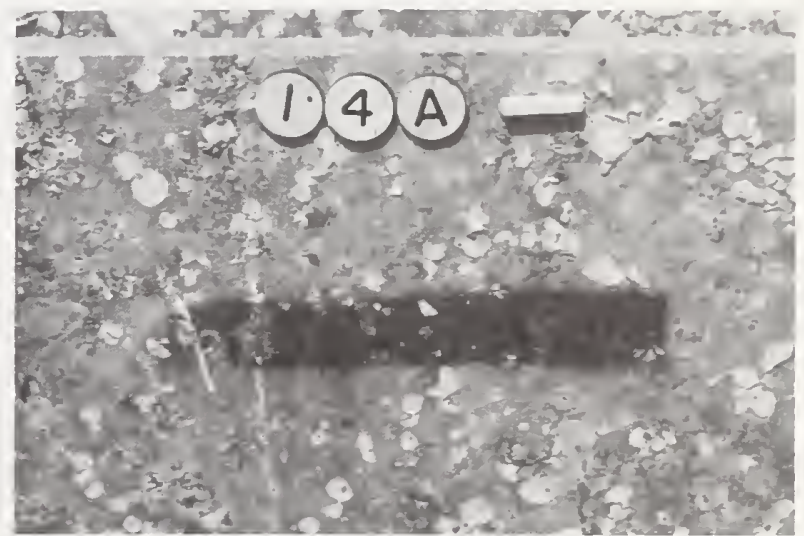

FigLKE 97

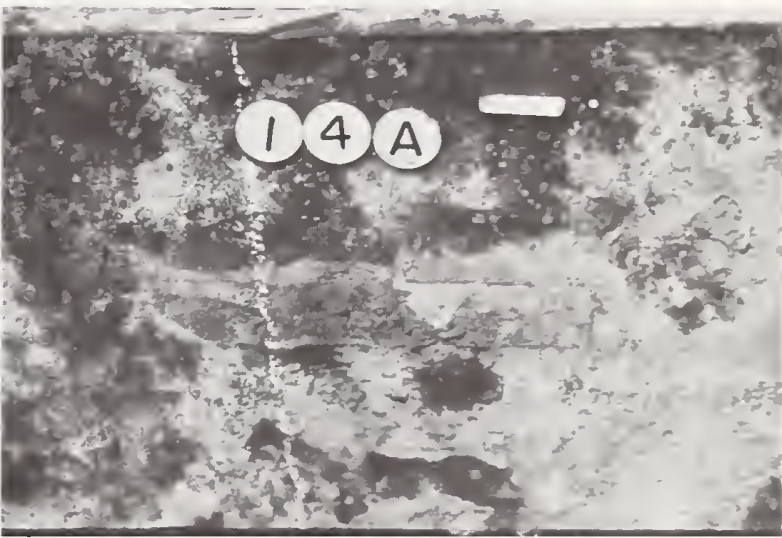

Figtre: 98

Siealed flamesprayed aluminum 
Table 2 - Potentials of Cathodically Protected Steel Piles Over a Period of 8 Years of Exposure (Offshore) in the Atlantic Ocean at Oam Neck, Virginia.

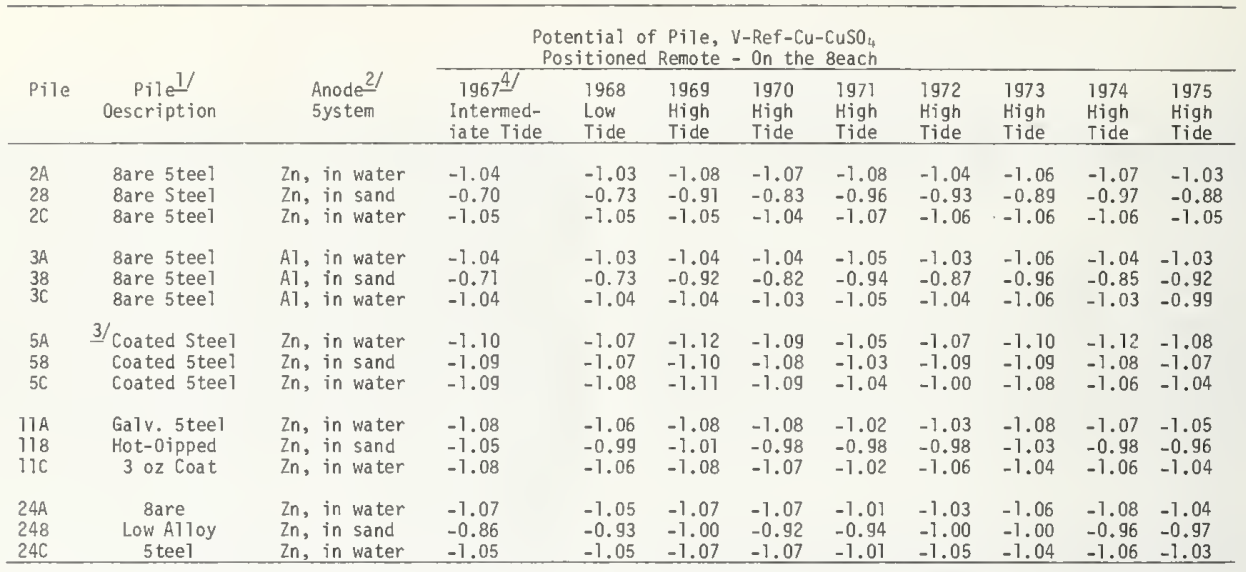

I/A11 piles, except system 24, are mild carbon steel, all are H-piles, 8 in. $x 8$ in. $x 48$ lbs/ft. $-35 \mathrm{ft}$. $10 \mathrm{ng}$. In all cases, the sand line was from 19 to $21 \mathrm{ft}$. measured from the bottom of the pile, in general the row of $\mathrm{C}$ piles having the more sand. The length of a pile exposed to sand and water varied between $24 \mathrm{ft}$. and $28 \mathrm{ft}$., depending on the normal tide.

2/ Zinc anodes are $4 \mathrm{in}, \times 4 \mathrm{in}, \times 36 \mathrm{in}$, weighing 150 lbs. Aluminum anodes are 4 in. $\times 4$ in. $\times 38$ in. weighing 60 1bs. Each pile is protected by two anodes permanently mounted on opposite flanges at the same elevation. On the $\mathrm{A}$ and $\mathrm{C}$ piles, the anodes are mounted in the water zone between the sand line and the mean low water line. On the 8 piles, the anodes are mounted in the sand zone, the tops of the anodes being about $6 \mathrm{ft}$. below the sand 1 ine.

$3 /$ piles are coated with coal tar epoxy. Pile $A$ has 5 windows (bare area, 1 in. $x 6$ in.). Pile 8 was completely coated, and pile $c$ was completely coated except for the lower $12 \mathrm{ft}$, in the mud zone.

4 Initial measurements - made in 1967, 4 months after installation.

Table 3. Corrosion Rates of H-Piles Based on Flange Thickness Measurements

\begin{tabular}{|c|c|c|c|c|c|c|}
\hline \multirow[b]{2}{*}{ SYSTEM } & \multirow[b]{2}{*}{ COATING OESCRIPTION } & \multirow{2}{*}{$\begin{array}{c}\text { Overall } \\
\text { Average } \\
\text { Corrosion } \\
\text { Rate } \\
\text { mpy }\end{array}$} & \multicolumn{4}{|c|}{$\begin{array}{c}\text { Average Corrosion Rate Within Zone, } \\
\text { mpy }{ }^{\text {a }}\end{array}$} \\
\hline & & & $\begin{array}{c}\text { Imbedded } \\
\text { Zone } \\
0 \text { to } 15 \mathrm{ft} \text {. }\end{array}$ & $\begin{array}{c}\text { Erosion } \\
\text { Zone } \\
15 \text { to } 21 \mathrm{ft} .^{b}\end{array}$ & $\begin{array}{c}\text { Immersed } \\
\text { Zone } \\
15 \text { to } 29 \mathrm{ft}{ }^{b} \\
\end{array}$ & $\begin{array}{l}\text { Atmospheric } \\
\text { Zone } \\
29 \text { to } 35 \mathrm{ft}^{\text {b. }} \\
\end{array}$ \\
\hline 21 & Coal Tar Epoxy/Zinc Rich Inorganic & $<0.01$ & $<0.01$ & $<0.01$ & 0.01 & $<0.01$ \\
\hline 13 & Vinyl/Flame Sprayed Aluminum & 0.03 & 0.01 & 0.17 & 0.07 & 0 \\
\hline 20 & Epoxy Polyamide/Zinc Rich Inorganic & 0.05 & 0.02 & 0.22 & 0.10 & 0 \\
\hline 8 & Aluminum Pigmented Coal Tar Epoxy & 0.07 & 0.07 & 0.06 & 0.08 & 0.03 \\
\hline 29 & Polyester Glass Flake & $<0.10$ & $<0.10$ & $<0.10$ & $<0.10$ & $<0.10$ \\
\hline 15 & Polyvinylidere Chloride/Flame 5prayed Zinc & 0.10 & 0 & 0.14 & 0.12 & 0.29 \\
\hline 10 & Galvanized & 0.14 & 0 & 0.67 & 0.32 & 0.06 \\
\hline 17 & Phenolic Mastic & 0.14 & 0.11 & 0.11 & 0.15 & 0.21 \\
\hline 14 & Flame 5prayed Aluminum & 0.16 & 0.19 & 0.39 & 0.19 & 0.03 \\
\hline 9 & Aluminum Pigmented Coal Tar Epoxy & 0.18 & 0.18 & 0.08 & 0.21 & 0.04 \\
\hline 18 & Coal Tar Epoxy/Zinc Rich Organic & 0.19 & 0.17 & 0.15 & 0.21 & 0.24 \\
\hline 19 & Vinyl/Zinc Rich Inorganic & 0.20 & 0.19 & 0.22 & 0.18 & 0.31 \\
\hline 22 & Vinyl Mastic/Zinc Rich Inorganic & 0.24 & 0.02 & 1.4 & 0.61 & 0 \\
\hline 4 & Coal Tar Epoxy & 0.53 & 0.17 & 0.21 & 0.27 & 2.1 \\
\hline 25 & Coal Tar Epoxy on Mariner Steel & 0.53 & 0.18 & 0.44 & 0.45 & 1.6 \\
\hline 7 & Coal Tar Epoxy plus Armor & 0.55 & 0.13 & 0.07 & 0.07 & 2.7 \\
\hline 6 & Coal Tar Epoxy & 0.80 & 0.27 & 0.72 & 0.46 & 2.9 \\
\hline 16 & Vinyl-Red Lead/Flame 5prayed Zinc & 1.4 & 0.08 & 3.2 & 1.8 & 2.3 \\
\hline 12 & Polyvinylidene Chloride & 2.4 & 0.81 & 4.9 & 3.6 & 3.5 \\
\hline 30 & Bare Carbon 5teel & 4.9 & 0.9 & 8.9 & 6.7 & 10.5 \\
\hline 1 & Bare Carbon Steel & 6.0 & 1.8 & 9.7 & 7.9 & 12.2 \\
\hline 31 & 8are Carbon Steel & 7.3 & 2.8 & 10.5 & 9.0 & 13.9 \\
\hline 26 & 8are Carbon Steel & Pipe ${ }^{\mathrm{C}}$ & - & - & - & - \\
\hline 27 & Coal Tar Epoxy & Pipe $^{C}$ & - & - & - & - \\
\hline 28 & Coal Tar Epoxy plus Armor & Pipe $^{c}$ & - & - & - & - \\
\hline
\end{tabular}

aFor Iron: mils per year $\times 5.48$ = milligrams per square decimeter per day. boistance from bottom of pile.

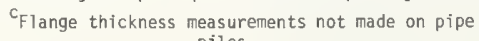
piles. 


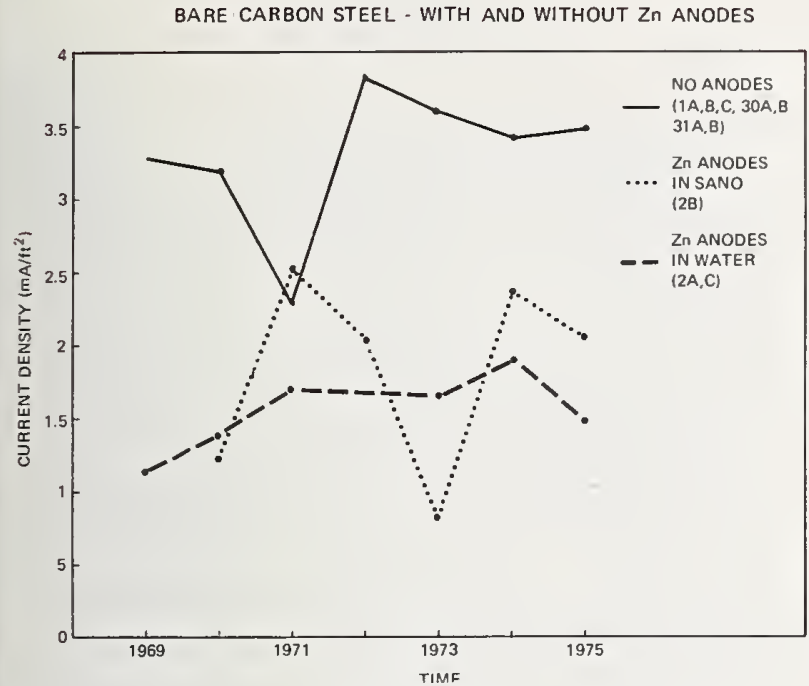

Figure 99

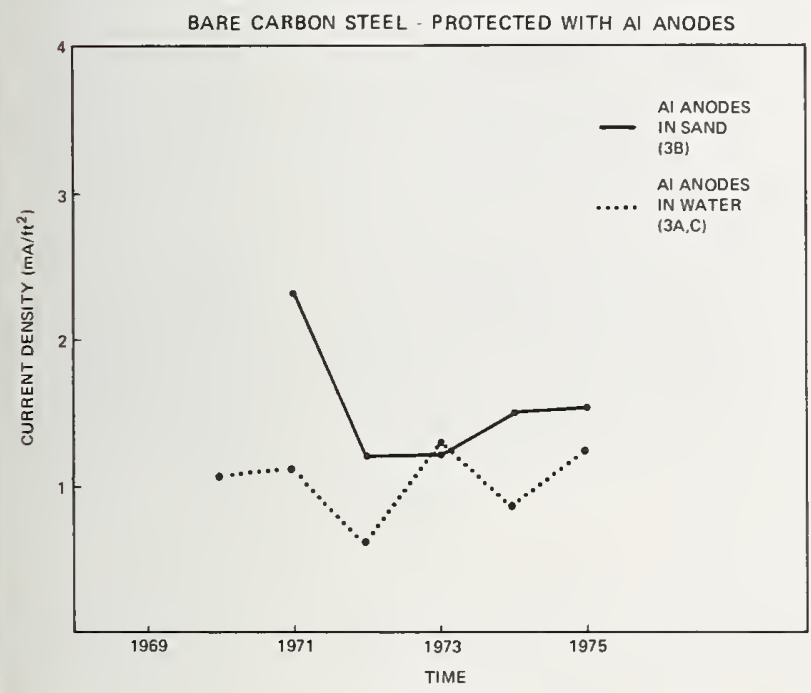

Figcre 100

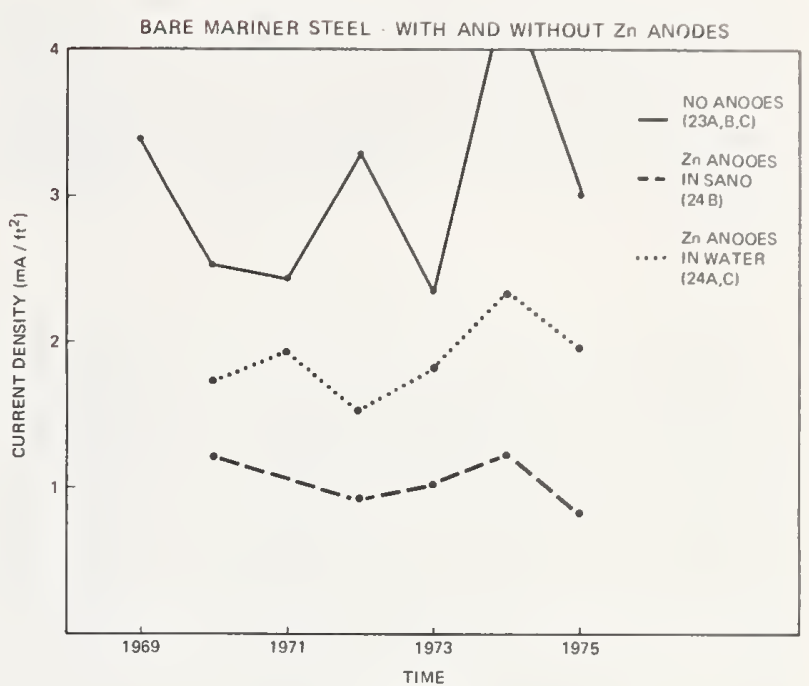

Figure 101

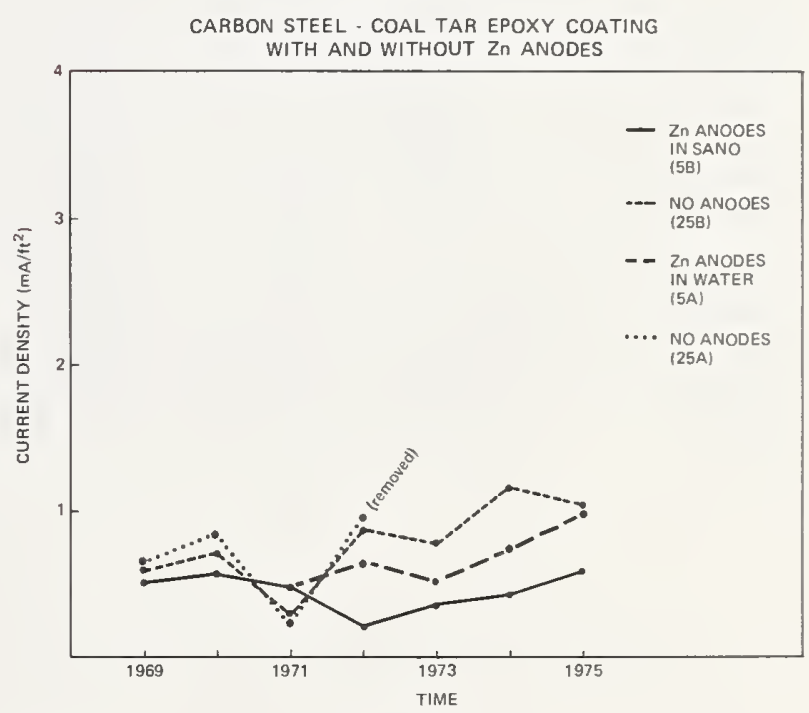

Figure 102

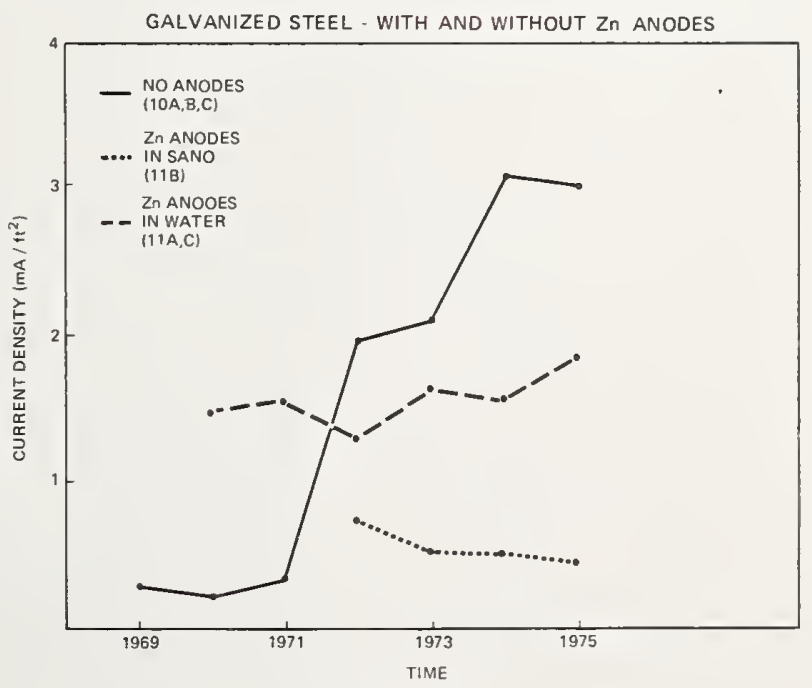

Figure 103 
with only one exception, the anodes located below the mud line are providing more protection than similar anodes above the mud line. These preliminary results on the cathodically protected systems must await verification pending their removal for physical examination.

The authors are grateful for the continuing cooperation and financial support of the American Iron and Steel Institute, and the funding aid from the U.S. Army Corp of Engineers at the initial phase of the program. In our own laboratory we wish to thank J. L. Fink and J. T. Hill for their valuable assistance in various phases of the work, and W. J. Schwerdtfeger (retired) for his many helpful discussions, suggestions, and participation at the start of the investigation. Appreciation is extended to the coating manufacturers who provided technical and material assistance, and the U.S. Navy Amphibious Construction Battalion No. 2 for installation and removal of the piles; to the U.S. Navy Fleet Combat Directions Systems Training Center for providing the site, and to the divers from the U.S. Navy Underwater Demolition Units for their aid in making electrical connections. This work is dedicated to the memory of Melvin Romanoff without whom the program would not have existed.

\section{References}

(1) Schwerdtfeger, W. J., J.Res. Nat. Bur. Stand. 60, No. 3, 153-159 (1958) RP2833.

[2] Burgbacher, J. A., Materials Protection, 6, No. 1, p. $56(1967)$.

[3] Cleary, H. J., J. of Metals, 22, No. 3, p. 39 (1970).

[4] Brouillette, C. V., Corrosion, 14, No. 8, p. 352 (1958).

[5] Peterson, M. H., and Waldron, L. J., Corrosion, 17, No. 4, p. 188t. (1961).

[6] Balala, B., Materials Protection and Performance, 11, No. 9, p. 30 (1972).

[7] Alumbaugh, R. L., Materials Protection, 3, No. 7, p. 34 (1964).

[8] Reinhart, F. M., Corrosion of Materials in Hydrospace, TR-504, U.S. Naval Civil Engineering Laboratory, Port Hueneme, California, Dec. (1966).

[9] Monney, N. T., Materials Protection and Performance, 12 , No. 1, p. 10 (1973).

[10] Larabee, C. P., Materials Protection, 1, No. 12, p. 95 (1962).

111] Watkins, L. L., J. Waterways, Harbors and Coastal Engr. Div., ASCE, 97, Proc. Paper 8292, 549 (1971).

1121 Romanoff, M., Gerhold, W. F., Schwerdtfeger, W. J., Iverson, W. P., Sanderson, B. T., Escalante, E., Watkins, L. L., Alumbaugh, R. L., Protection of Steel Piles in a Natural Seawater Environment-Part I Proceedings, 3rd International Congress on Marine Corrosion and Fouling, 1973.

[13] U.S. Dept. of Commerce ESSA, Coast and Geodetic Surv., Pub. 31-1, 4th ed. (1972).

[14] Stern, M., and Geary, A. L., J. Electrochem. Soc. 104, No. 1, p. 56 (1957).

[15] Schwardtfeger, W. J. and McDorman, O. N., J. Electrochem. Soc., 99, No. 10, p. 407 (1952).

[16] Schwerdtfeger, W. J., ASTM Mat. Res. and Stand. 10, No. 3, p. $22(1970)$. 


\section{Index}

Piling

System

Number

1

2

3

4

5

6
Coating or Protection System

Bare Carbon Steel

Bare Carbon Steel ( $\mathrm{Zn}$ anodes)

Bare Carbon Steel (A1 anodes)

Coal Tar Epoxy

Coal Tar Epoxy (Zn anodes)

Coal Tar Epoxy

Coal Tar Epoxy plus Armor

Aluminum Pigmented Coal Tar Epoxy

Aluminum Pigmented Coal Tar Epoxy

Galvanized

Galvanized ( $\mathrm{Zn}$ anodes)

Polyvinylidene Chloride

Vinyl/Aluminum Flame Spray

Aluminum Flame Spray

Polyvinlyidene Chloride/Zinc Flame Spray

Vinyl/Flame Spray Zinc

Phenolic Mastic

Coal Tar Epoxy/Organic Zine Rich

Vinyl/Inorganic Zinc Rich

Epoxy Polyamide/Inorganic Zinc Rich

Coal Tar Epoxy/Inorganic Zine Rich

Vinyl Mastic/Inorganic Zinc Rich

Bare Mariner Steel

Bare Mariner Steel ( $\mathrm{Zn}$ anodes)

Coal Tar Epoxy on Mariner Steel

Bare Carbon Steel

Coal Tar Epoxy

Coal Tar Epoxy plus Armor

Polyester Glass Flake

Bare Carbon Steel

Bare Carbon Steel
Text

Pag'e

29

30

8

30

8

30

18

18

28

30

16

24

28

24

24

\section{Figures}

2, 5, 6, 90, 99

99

10,100

$10,15,21,22,23$

2, 102

$10,11,12,13,14$

$10,16,18,19,20$

$48,49,50,51,52$

$48,53,54,55,56$

$90,91,92,93,94,103$

103

$35,44,45,46,47$

$78,79,80,81,82$

$90,95,96,97,98$

$78,83,84,85$

$78,86,87,88,89$

$35,36,37,38,39$

$57,58,59,60,61$

$57,70,71,72,73$

$57,62,63,64,65$

$57,66,67,68,69$

$57,74,75,76,77$

5,101

101

$10,17,24,25,26,102$

9

$10,27,29,30,31$

$10,28,32,33,34$

$35,40,41,42,43$

5, 99

8,99
Table

1,3

1, 2

1, 2

1, 3

1, 2

1, 3

1, 3

1, 3

1,3

1,3

1, 2

1, 3

1,3

1, 3

1,3

1,3

1,3

1,3

1, 3

1,3

1,3

1,3

1

1, 2

1,3

1,3

1,3

1,3

1, 3

1,3

1 
NBS-114A (REV. 7-73)

\begin{tabular}{|c|c|c|}
\hline $\begin{array}{l}\text { U.S. DEPT. OF COMM. } \\
\text { BIBLIOGRAPHIC DATA } \\
\text { SHEET }\end{array}$ & \begin{tabular}{|l|l} 
1. PUBLICATION OR REPORTNO. & $\begin{array}{l}\text { 2. Gov't Accession } \\
\text { No. }\end{array}$
\end{tabular} & 3. Recipient's Accession No. \\
\hline \multirow[t]{2}{*}{ 4. TITLE AND SUBTITLEE } & \multirow[t]{2}{*}{$\begin{array}{l}\text { Corrosion and Protection of Steel Piles } \\
\text { in a Natural Seawater Environment }\end{array}$} & $\begin{array}{r}\text { 5. Publication Date } \\
\text { June } 1977\end{array}$ \\
\hline & & 6. Performing Organization Code \\
\hline \multicolumn{2}{|c|}{$\begin{array}{l}\text { 7. AUTHOR(S) E. Escalante, W. P. Iverson, W.F. Gerhold, } \\
\text { E. T. Sanderson, R. L. Alumbaugh }\end{array}$} & 8. Performing Organ. Report No. \\
\hline \multicolumn{2}{|c|}{$\begin{array}{l}\text { 9. PERFORMING ORGANIZATION NAME AND ADDRESS } \\
\text { NATIONAL BUREAU OF STANDARDS } \\
\text { DEPARTMENT OF COMMERCE } \\
\text { WASHINGTON, D.C. } 20234\end{array}$} & $\begin{array}{l}\text { 10. Project/Task/Work Unit No. } \\
\text { Progress Report } \\
\text { 11. Contract/Grant No. }\end{array}$ \\
\hline \multirow{2}{*}{\multicolumn{2}{|c|}{$\begin{array}{l}\text { 12. Sponsoring Otganization Name and Complete Address (Street, City, State, ZIP) } \\
\text { American Iron and Steel Institute } \\
\text { 1000 16th St. N.W. } \\
\text { Washington, D. C. } 20036\end{array}$}} & $\begin{array}{l}\text { 13. Type of Report \& Period } \\
\text { Covered } \\
\text { Final }\end{array}$ \\
\hline & & 14. Sponsoring Agency Code \\
\hline \multicolumn{3}{|c|}{$\begin{array}{l}\text { 15. SUPPLEMENTARY NOTES Originally printed for limited distribution to sponsor as } \\
\text { NBSIR 76-1104. This document has gone through the editorial review. } \\
\text { Library of Congress Catalog Card Number: } 76-608410\end{array}$} \\
\hline
\end{tabular}

16. ABSTRACT (A 200-word or less factual summary of most significant information. If document includes a significant bibliography or literature survey, mention it here.)

This report describes the first eight years of a long term program in which twenty-three coating systems and five cathodic protection systems are evaluated on their ability to protect steel piles in offshore conditions. These systems are made up of nonmetallic coatings, metallic pigmented coatings, nonmetallic coatings on metal filled coatings, nonmetallic coatings on metallic coatings, metallic coatings, and cathodic protection on bare and coated piles.

It includes a description of the annual on site electrochemical coating evaluation and a description of the final physical evaluation rnade on the piles after removal. The results of these electrochemical and physical evaluations are presented graphically and in tabular form.

17. KEY WORDS (six to twelve entries; alphabetical order; capitalize only the first letter of the first key word unless a proper name; separated by semicolons)

Cathodic protection; coating systems; corrosion protection; offshore corrosion; sand corrosion; seawater corrosion; splash zone corrosion.

\section{Xnlimited}

For Official Distribution. Do Not Release to NTIS

X Order From Sup. of Doc., U.S. Government Pyigtips 8 ffice
Washington, D.C. 20402, SD Cat. No.C13 44.158 .

$\square$ Order From National Technical Information Service (NTIS) Springfield, Virginia 22151

\begin{tabular}{|l|c|}
\begin{tabular}{|l|} 
19. SECURITY CLASS \\
(THIS REPORT)
\end{tabular} & 21. NO. OF PAGES \\
UNCLASSIFIED & 42 \\
\hline $\begin{array}{l}\text { 20. SECURITY CLASS } \\
\text { (THIS PAGE) } \\
\text { UNCLASSIFIED }\end{array}$ & 22. Price $\$ 1.60$ \\
\hline
\end{tabular}




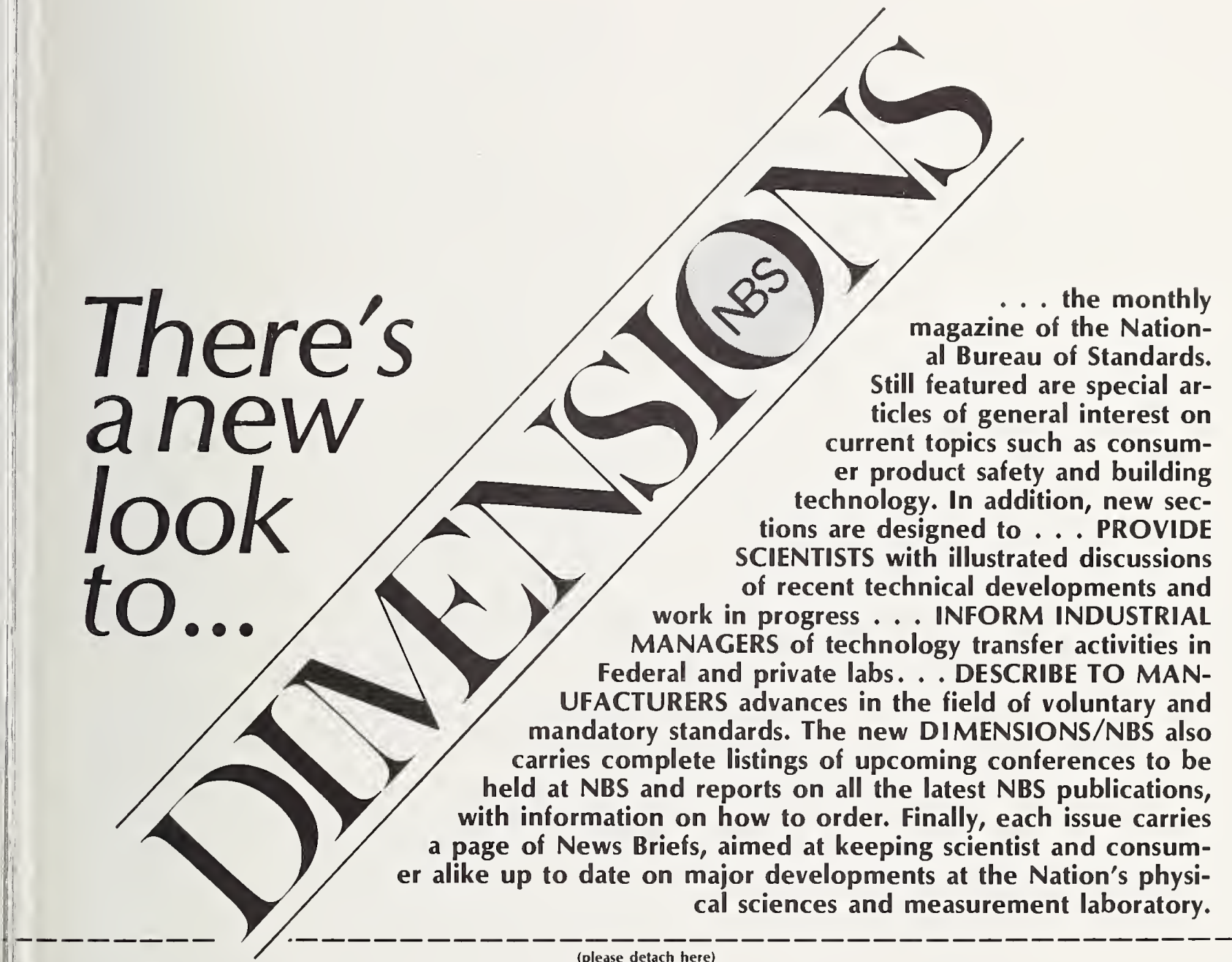

SUBSCRIPTION ORDER FORM

Enter my Subscription To DIMENSIONS/NBS at \$12.50. Add \$3.15 for foreign mailing. No additional postage is required for mailing within the United States or its possessions. Domestic remittances should be made either by postal money order, express money order, or check. Foreign remittances should be made either by international money order, draft on an American bank, or by UNESCO coupons.

Send Subscription to:

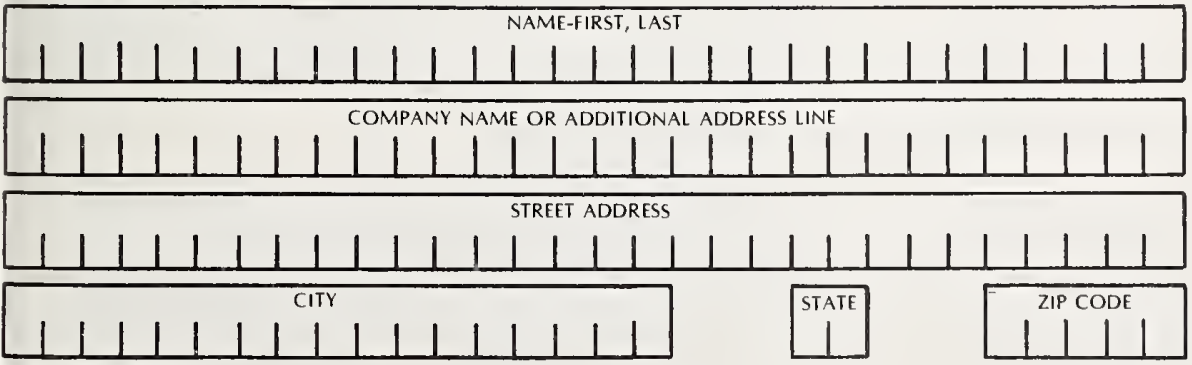

Remittance Enclosed (Make checks payable to Superintendent of Documents)

Charge to my Deposit Account No.

MAIL ORDER FORM TO:

Superintendent of Documents

Government Printing Office

Washington, D.C. 20402 



\section{PERIODICALS}

JOURNAL OF RESEARCH reports National Bureau of Standards research and development in physics, mathematics, and chemistry. It is published in two sections, available separately:

- Physics and Chemistry (Section A)

Papers of interest primarily to scientists working in these fields. This section covers a broad range of physical and chemical research, with major emphasis on standards of physical measurement, fundamental constants, and properties of matter. Issued six times a year. Annual subscription: Domestic, $\$ 17.00$; Foreign, $\$ 21.25$.

- Mathematical Sciences (Section B)

Studies and compilations designed mainly for the mathematician and theoretical physicist. Topics in mathematical statisties, theory of experiment design, numerical analysis, theoretical physics and chemistry, logical design and programming of computers and computer systems. Short numerical tables. Issued quarterly. Annual subscription: Domestic, $\$ 9.00$; Foreign, $\$ 11.25$.

DIMENSIONS/NBS (formerly Technical News Bulletin)-This monthly magazine is published to inform scientists, engineers, businessmen, industry, teachers, students, and consumers of the latest advances in science and technology, with primary emphasis on the work at NBS. The magazine highlights and reviews such issues as energy research, fire protection, building technology, metric conversion, pollution abatement, health and safety, and consumer product performance. In addition, it reports the results of Bureau programs in measurement standards and techniques, properties of matter and materials, engineering standards and services, instrumentation, and automatic data processing.

Annual subscription: Domestic, $\$ 12.50$; Foreign, $\$ 15.65$.

\section{NONPERIODICALS}

Monographs-Major contributions to the technical literature on various subjects related to the Bureau's scientific and technical activities.

Handbooks-Recommended codes of engineering and industrial practice (including safety codes) developed in cooperation with interested industries, professional organizations, and regulatory bodies.

Special Publications-Include proceedings of conferences sponsored by NBS, NBS annual reports, and other special publications appropriate to this grouping such as wall charts, pocket cards, and bibliographies.

Applied Mathematics Series-Mathematical tables, manuals, and studies of special interest to physicists, engineers, chemists, biologists, mathematicians, computer programmers, and others engaged in scientific and technical work.

National Standard Reference Data Series-Provides quantitative data on the physical and chemical properties of materials, compiled from the world's literature and critically evaluated. Developed under a world-wide program coordinated by NBS. Program under authority of National Standard Data Act (Public Law 90-396).
NOTE: At present the principal publication outlet for these data is the Journal of Physical and Chemical Reference Data (JPCRD) published quarterly for NBS by the American Chemical Society (ACS) and the American Institute of Physics (AIP). Subscriptions, reprints, and supplements available from ACS, 1155 Sixteenth St. N.W., Wash. D. C. 20056.

Building Science Series-Disseminates technical information developed at the Bureau on building materials, components, systems, and whole structures. The series presents research results, test methods, and performance criteria related to the structural and environmental functions and the durability and safety characteristics of building elements and systems.

Technical Notes-Studies or reports which are complete in themselves but restrictive in their treatment of a subject. Analogous to monographs but not so comprehensive in scope or definitive in treatment of the subject area. Often serve as a vehicle for final reports of work performed at NBS under the sponsorship of other government agencies.

Voluntary Product Standards-Developed under procedures published by the Department of Commerce in Part 10, Title 15, of the Code of Federal Regulations. The purpose of the standards is to establish nationally recognized requirements for products, and to provide all concerned interests with a basis for common understanding of the characteristics of the products. NBS administers this program as a supplement to the activities of the private sector standardizing organizations.

Consumer Information Series-Practical information, based on NBS research and experience, covering areas of interest to the consumer. Easily understandable language and illustrations provide useful background knowledge for shopping in today's technological marketplace.

Order above NBS publications from: Superintendent of Documents, Government Printing Office, Washington, D.C. 20402 .

Order following NBS publications-NBSIR's and FIPS from the National Technical Information Services, Springfield, Va. 22161.

Federal Information Processing Standards Publications (FIPS PUBS) - Publications in this series collectively constitute the Federal Information Processing Stand. ards Register. Register serves as the official source of information in the Federal Government regarding standards issued by NBS pursuant to the Federal Property and Administrative' Services Act of 1949 as amended, Public Law 89-306 (79 Stat. 1127), and as implemented by Executive Order 11717 (38 FR 12315, dated May 11, 1973) and Part 6 of Title 15 CFR (Code of Federal Regulations).

NBS Interagency Reports (NBSIR)-A special series of interim or final reports on work performed by NBS for outside sponsors (both government and non-government). In general, initial distribution is handled by the sponsor; public distribution is by the National Technical Information Services (Springfield, Va. 22161) in paper copy or microfiche form.

\section{BIBLIOGRAPHIC SUBSCRIPTION SERVICES}

The following current-awareness and literature-survey bibliographies are issued periodically by the Bureau:

Cryogenic Data Center Current Awareness Service. A literature survey issued biweekly. Annual subscription: Domestic, $\$ 25.00$; Foreign, $\$ 30.00$.

Liquified Natural Gas. A literature survey issued quarterly. Annual subscription: $\$ 20.00$.
Superconducting Devices and Materials. A literature survey issued quarterly. Annual subscription: $\$ 30.00$. Send subscription orders and remittances for the preceding bibliographic services to National Bureau of Standards, Cryogenic Data Center (275.02) Boulder, Colorado 80302. 
U.S. DEPARTMENT OF COMMERCE

National Bureau of Standards

Washington, D.C. 20234

POSTAGE ANO FEES PAID U.5. OEPARTMENT DF COMMERCE COM-2is

OFFICIAL BUSINESS

Penalty for Private Use. $\$ 300$

SPECIAL FOURTH-CLASS RATE BOOK 